$$
A N L / D-D / T M--96 / 3
$$

ANL/D\&D/TM-96/3

\title{
Decontamination and Decommissioning of 61 Plutonium Gloveboxes in D-Wing, Building 212 Argonne National Laboratory - East: Final Project Report
}

by C.L. Cheever and R.W. Rose

Decontamination and Decommissioning Program, Technology Development Division, Argonne National Laboratory, 9700 South Cass Avenue, Argonne, Illinois 60439

Work sponsored by United States Department of Energy,

Office of Environmental Management 


\section{DISCLAIMER}

Portions of this document may be illegible in electronic image products. Images are produced from the best available original document. 


\section{CONTENTS}

ACKNOWLEDGMENTS $\ldots \ldots \ldots \ldots \ldots \ldots \ldots \ldots \ldots \ldots \ldots \ldots \ldots \ldots \ldots$ vii

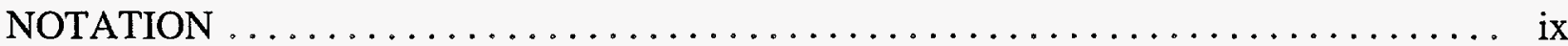

EXECUTIVE SUMMARY $\ldots \ldots \ldots \ldots \ldots \ldots \ldots \ldots \ldots \ldots \ldots \ldots \ldots \ldots \ldots$

1 INTRODUCTION $\ldots \ldots \ldots \ldots \ldots \ldots \ldots \ldots \ldots \ldots \ldots \ldots \ldots \ldots \ldots \ldots \ldots$

2 BACKGROUND: FACILITY HISTORY $\ldots \ldots \ldots \ldots \ldots \ldots \ldots \ldots \ldots \ldots$

3 DECOMMISSIONING OBJECTIVE AND WORK SCOPE $\ldots \ldots \ldots \ldots \ldots \ldots$

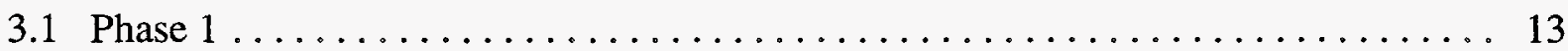

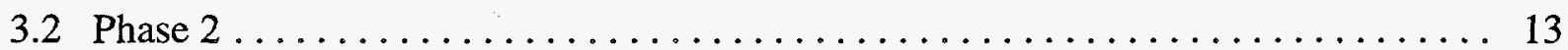

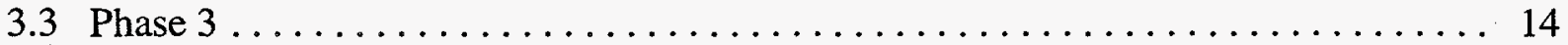

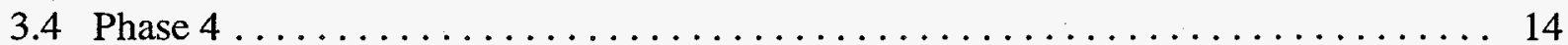

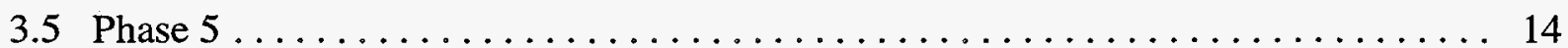

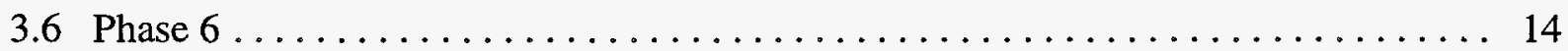

4 WORK PERFORMED $\ldots \ldots \ldots \ldots \ldots \ldots \ldots \ldots \ldots \ldots \ldots \ldots \ldots \ldots \ldots$

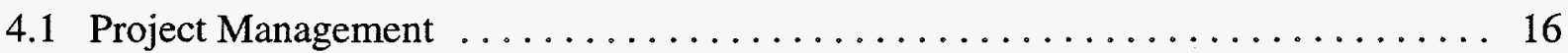

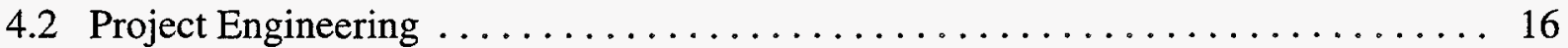

4.3 Characterization ................................. 19

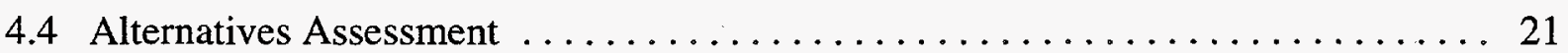

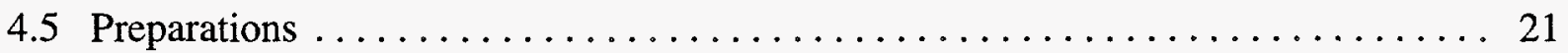

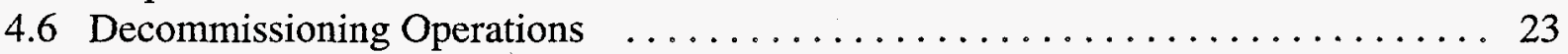

4.7 Waste Disposal . . . . . . . . . . . . . . . . . . . . . . . . . 42

4.8 Post-decommissioning Radiological Survey . . . . . . . . . . . . . . . 42

4.9 Post-decommissioning Hazardous Chemical Condition . . . . . . . . . . . . . . 49

5 COSTS AND SCHEDULES $\ldots \ldots \ldots \ldots \ldots \ldots \ldots \ldots \ldots \ldots \ldots \ldots \ldots \ldots$

6 WASTE GENERATED $\ldots \ldots \ldots \ldots \ldots \ldots \ldots \ldots \ldots \ldots \ldots \ldots \ldots \ldots \ldots$

7 OCCUPATIONAL EXPOSURE TO PERSONNEL $\ldots \ldots \ldots \ldots \ldots \ldots \ldots \ldots \ldots$

8 FINAL FACILITY STATUS $\ldots \ldots \ldots \ldots \ldots \ldots \ldots \ldots \ldots \ldots \ldots \ldots \ldots \ldots$

9 LESSONS LEARNED AND DOE REPORTABLE OCCURRENCES $\ldots \ldots \ldots \ldots$

9.1 Lessons Learned $\ldots \ldots \ldots \ldots \ldots \ldots \ldots \ldots \ldots \ldots \ldots \ldots \ldots \ldots \ldots \ldots$

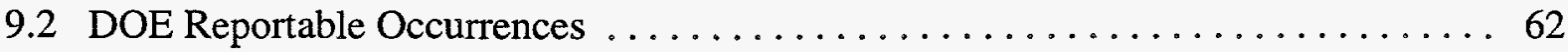




\section{CONTENTS (Cont.)}

10 CONCLUSIONS AND RECOMMENDATIONS

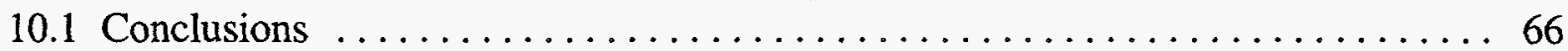

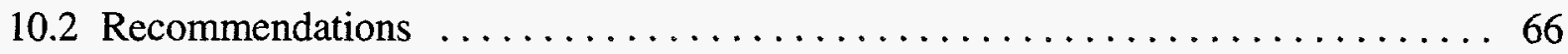

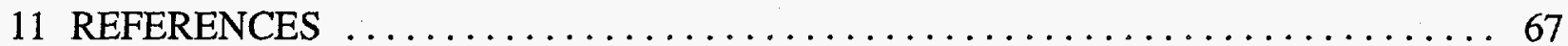

\section{TABLES}

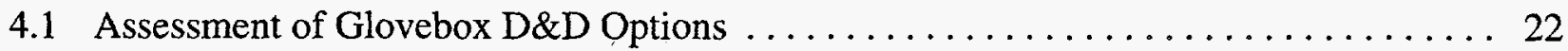

4.2 Phased Operation Glovebox Identification and Action Levels . . . . . . . . . . . . . 32

4.3 Personal Protective Clothing and Equipment for Glovebox Disassembly . . . . . . . 34

4.4 DOE Unrestricted Release Criteria . . . . . . . . . . . . . . . . . . . . . . 43

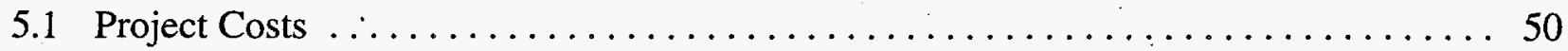

6.1 Radioactive Waste Generated $\ldots \ldots \ldots \ldots \ldots \ldots \ldots \ldots \ldots \ldots \ldots \ldots \ldots \ldots$

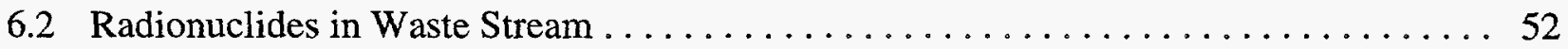

7.1 Radiation Doses Received by Workers $\ldots \ldots \ldots \ldots \ldots \ldots \ldots \ldots \ldots \ldots \ldots$

FIGURES

1.1 Map Showing ANL-E Location in the Greater Chicago Metropolitan Area . . . . . . 4

1.2 ANL-E Site Plan Showing Location of Building $212 \ldots \ldots \ldots \ldots \ldots \ldots$

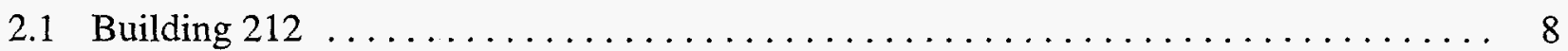

2.2 Plan View of D-Wing 2nd Floor, Building $212 \ldots \ldots \ldots \ldots \ldots \ldots \ldots \ldots \ldots \ldots \ldots$

2.3 Plan View of D-Wing 1st floor, Building $212 \ldots \ldots \ldots \ldots \ldots \ldots \ldots \ldots$

2.4 Building 212 Floorplan $\ldots \ldots \ldots \ldots \ldots \ldots \ldots \ldots \ldots \ldots \ldots \ldots \ldots \ldots \ldots \ldots$ 


\section{FIGURES (Cont.)}

2.5 Once-Through $\mathrm{N}_{2}$ System for Plutonium Gloveboxes $\ldots \ldots \ldots \ldots \ldots \ldots \ldots \ldots$

4.1 Project Organization Chart for the Building 212 Plutonium Gloveboxes D\&D . . . . 17

4.2 Plan View of the Glovebox Size-Reduction Enclosure $\ldots \ldots \ldots \ldots \ldots \ldots \ldots \ldots$

4.3 Plutonium Gloveboxes Prior to Decommissioning $\ldots \ldots \ldots \ldots \ldots \ldots \ldots \ldots$

4.4 View Inside Plutonium Glovebox Prior to Decommissioning . . . . . . . . . . . . 24

4.5 Preparing Disassembled Plutonium Glovebox Equipment for Bag Out $\ldots \ldots \ldots \ldots 25$

4.6 Preparing for Bag Out of Size-Reduced Equipment in a Plutonium Glovebox . . . . . 25

4.7 Bag Out of Size-Reduced Equipment from a Plutonium Glovebox . . . . . . . . 26

4.8 Heat Sealing of Bag of TRU Radioactive Waste $\ldots \ldots \ldots \ldots \ldots \ldots \ldots \ldots \ldots \ldots$

4.9 Loading Bagged Glovebox Materials into a Waste Drum . . . . . . . . . . 27

4.10 Disassembly of Plutonium Glovebox Equipment - Close-Up . . . . . . . . . . . 28

4.11 Disassembly of Plutonium Glovebox Equipment $\ldots \ldots \ldots \ldots \ldots \ldots \ldots \ldots$

4.12 Disassembly and Surveying of Mechanical Vacuum Pumps from Plutonium Glovebox Systems ............................. 30

4.13 Surveying Bagged Low-Level Radioactive Waste Loaded into a Bin Liner . . . . . . . 30

4.14 Pajarito Assaying of Decontaminated Gloveboxes $\ldots \ldots \ldots \ldots \ldots \ldots \ldots$

4.15 Cumulative Estimated vs Measured DAC-hrs $\ldots \ldots \ldots \ldots \ldots \ldots \ldots \ldots \ldots \ldots$

4.16 Gloveboxes Size-Reduction Enclosure $\ldots \ldots \ldots \ldots \ldots \ldots \ldots \ldots \ldots \ldots \ldots$

4.17 Size-Reduction of Plutonium Gloveboxes $\ldots \ldots \ldots \ldots \ldots \ldots \ldots \ldots \ldots$

4.18 Stretch-Wrap on Glovebox Frame and Wet Cheesecloth Covering of the Baseplate Prior to Size-Reduction $\ldots \ldots \ldots \ldots \ldots \ldots \ldots \ldots \ldots \ldots \ldots \ldots \ldots \ldots$

4.19 Saber Saw Cutting of a Stretch-Wrapped Glovebox Frame and High Volume Air Filter Sampling . . . . . . . . . . . . . . . . . . . 37 


\section{FIGURES (Cont.)}

4.20 Circular Saw Cutting of a Glovebox Baseplate Using a Portable

HEPA Filtered Local Exhaust Enclosure . . . . . . . . . . . . . . . . . . 38

4.21 Wrapping Size-Reduced Glovebox Baseplate with a Stretch-Wrap . . . . . . . . . . 39

4.22 Wet Wiping for Decontamination of a Size-Reduction Enclosure Floor

Covering Following Disassembly and Packaging of a Glovebox $\ldots \ldots \ldots \ldots . .40$

4.23 Health Physics Technician Frisking a Rigger Employee ................. 41

4.24 Loaded Super Tiger Truck Shipment of Type B Radioactive Waste ............. 43

4.25 Health Physics Technicians Marking $1 \mathrm{~m}^{2}$ Grids on Laboratory

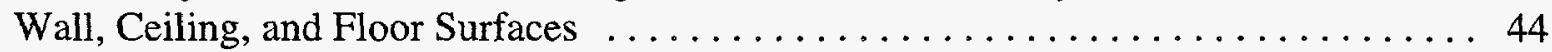

4.26 Health Physics Technician Surveying a Wall Surface from a Motorized

Scissors-Lift Platform Using a $435 \mathrm{~cm}^{2}$ Probe Gas-Proportional Counter . ....... 45

4.27 Health Physics Technician Surveying an Electrical Strip Using

a $100 \mathrm{~cm}^{2}$ Probe Scintillation-Type Instrument . . . . . . . . . . . . . 46

4.28 Health Physics Technician Surveying a Laboratory Floor with a $330 \mathrm{~cm}^{2}$ Probe Gas-Proportional Counter

4.29 Health Physics Technician Taking a Dry Smear Sample of a $100 \mathrm{~cm}^{2}$ Wall Area ...................................... 48

4.30 Health Physics Technician Collecting a Paint Sample Using a Power-Operated Wire Cone Brush with Exhaust Filter Attachment ................... 48

6.1 Estimated vs Actual Amount of Radioactive Waste Generated .............. 53

6.2 Radionuclides Distribution $\ldots \ldots \ldots \ldots \ldots \ldots \ldots \ldots \ldots \ldots \ldots \ldots \ldots \ldots \ldots \ldots \ldots \ldots \ldots$

7.1 Comparison of Budgeted, Estimated, and Actual Internal Exposure

Received During Glovebox Size-Reduction and Packaging $\ldots \ldots \ldots \ldots \ldots \ldots 6$

8.1 Final Status of Laboratory DL-216 $\ldots \ldots \ldots \ldots \ldots \ldots \ldots \ldots \ldots \ldots \ldots \ldots \ldots \ldots \ldots$

8.2 Final Status of Laboratory DL-222 $\ldots \ldots \ldots \ldots \ldots \ldots \ldots \ldots \ldots \ldots \ldots \ldots$

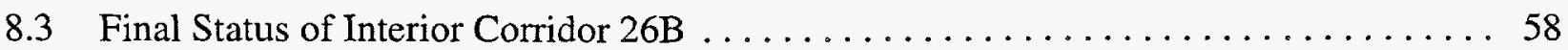




\section{ACKNOWLEDGMENTS}

The decontamination and decommissioning project was performed in six phases using different resources to complete the various phases. The project was managed initially by Environmental Management Operations and later by Technology Development. Staffing for the first phase was with Building 212 personnel who were familiar with the gloveboxes and their contents. Equipment and materials small enough for bag out without size-reduction and accountable radioactive material were identified, recorded, and bagged out of the gloveboxes by Energy Technology and Material Science Division personnel. Size-reduction and bag-out of additional equipment and removal of glovebox external equipment was performed by Environmental Management Operations personnel with some assistance from Engineering Technology and Material Science Division personnel. The radioactive waste staging and disposal services were provided by Environmental Management Operations personnel. The removal of the large equipment, decontamination, assay, and size-reduction of the gloveboxes was contracted out to Nuclear Fuel Services, Inc. The contractor used the SEG, RPS, and Pajarito Scientific Corporations for subcontracting services. Argonne National Laboratory-East Environment, Safety, and Health, Health Physics, provided the health physics oversight of the contractor and subcontractor and directed health physics services for Argonne National Laboratory-East decontamination and decommissioning work. Health Physics also performed the final radiological survey. Documentation services were provided by the Environmental Assessment Division for the Action Description Memorandum and by NES, Inc. for the Cost Estimate and the Safety Analysis Report. An "Assessment of Options for the Decontamination and Decommissioning of Plutonium Gloveboxes" was contracted to and performed by BNFL, Inc.

\section{Technology Development}

L. Cheever and R. Rose- Project Manager(s)

P. Carlson- Field Engineer

M. Coffey and E. Stacy- Project Engineer(s)

\section{Environmental Management Operations}
T. Lahey- Foreman
G. Harris
W. Ray- Foreman
M. Harris
E. Armand
D. Kuzma
K. Borman
G. Redman
L. Cochara
J. Smeets
M. Davis
I. Vaughn
J. Gleason
C. Wood 
Engineering Technology

D. Diercks- Group Leader

R. Lee

C. Konicek- Chief Technician

D. Perkins

A. Mitchell- (Material Science Division)

S. Phillips

G. Dragel

K. Stair

T. Galvin

J. Tezak

Environment, Safety and Health

W. Munyon- Health Physicist

W. Knoezer

G. Ketchmark-Chief Technician

W. Krueger

J. Alicz

J. Reed

M. Gatzke

L. Sprouse, Jr.

G. Haruch

W. Stigberg, Jr.

T. Klochan

Environmental Assessment

H. Avci

Contractor- Nuclear Fuel Services, Inc.

Subcontractors:

SEG Corp., RPS Corp., and Pajarito Scientific Corp.

\section{Other Contractor Services}

BNFL, Inc.

NES, Inc. 
Acronyms, Initialisms, and Abbreviations

$\begin{array}{ll}\text { AA } & \text { Argonne Area } \\ \text { ADM } & \text { Action Description Memorandum } \\ \text { ALARA } & \text { As Low As Reasonably Achievable } \\ \text { ANL-E } & \text { Argonne National Laboratory - East } \\ & \\ \text { Bq } & \text { Becquerel } \\ & \\ \text { CAM } & \text { Continuous air monitor } \\ \text { CDR } & \text { Conceptual Design Report } \\ \text { CEDE } & \text { Collective effective dose equivalent } \\ \text { CEMP } & \text { Comprehensive Emergency Management Plan } \\ \text { cf } & \text { Cubic feet } \\ \text { cfm } & \text { cubic feet per minute } \\ \text { CH } & \text { Chicago } \\ \text { CTZ } & \text { Central Time Zone } \\ \text { CX } & \text { Categorical Exclusion } \\ \text { CYWP } & \text { Current Year Work Plan } \\ & \\ \text { DAC } & \text { Derived Air Concentration } \\ \text { D\&D } & \text { Decontamination and Decommissioning } \\ \text { DOE } & \text { Department of Energy } \\ \text { DOP } & \text { Dioctyl phthalate } \\ \text { DOT } & \text { Department of Transportation } \\ \text { dpm } & \text { Disintegrations per minute } \\ & \\ \text { EA } & \text { Environmental Assessment } \\ \text { EE } & \text { Environmental Evaluation } \\ \text { EMO } & \text { Environmental Management Operations } \\ \text { EPA } & \text { Environmental Protection Agency } \\ \text { ER } & \text { Energy Research } \\ \text { ESH } & \text { Environment, Safety, and Health } \\ \text { ET } & \text { Energy Technology } \\ \text { EWM } & \text { Environmental Waste Management } \\ & \end{array}$

FY

Fiscal Year 


$\begin{array}{ll}\text { G } & \text { Giga }\left(10^{9}\right) \\ \text { gal } & \text { gallon } \\ \text { GM } & \text { Geiger-Mueller } \\ \text { GY } & \text { Gray } \\ \text { HEPA } & \text { High Efficiency Particulate Air } \\ \text { HP } & \text { Health Physics } \\ & \\ \text { IH } & \text { Industrial Hygiene } \\ \text { IL } & \text { Illinois } \\ \text { LLW } & \text { Low Level Waste } \\ \text { m } & \text { Meter } \\ \text { m } & \text { Mili } \\ \text { m } & \text { Cubic meters } \\ \text { mil } & \text { Millimeter } \\ \text { MSD } & \text { Material Science Division } \\ \text { NEPA } & \text { National Environmental Protection Act } \\ \text { NFS } & \text { Nuclear Fuel Services, Inc. } \\ \text { ORISE } & \text { Oak Ridge Institute for Science and Education } \\ \text { PA } & \text { Public Address } \\ \text { PAPR } & \text { Pressurized-air-purifying respirator } \\ \text { PCB } & \text { Polychlorinated biphenyl } \\ \text { PVC } & \text { Polyvinyl chloride } \\ \text { rad } & \text { radioactive } \\ \text { RCRA } & \text { Resource Conservation and Recovery Act } \\ \text { rem } & \text { Roentgen equivalent man } \\ \text { s } & \text { second } \\ \text { S\&M } & \text { Surveillance and Maintenance } \\ \text { SAR } & \text { Safety Analysis Report } \\ \text { SE } & \text { Safety Engineering } \\ \text { Sv } & \text { Sievert } \\ \text { T } & \text { Tera (10 } 12 \text { ) } \\ \text { TEDE } & \text { Technology Development } \\ \text { Total effective dose equivalent }\end{array}$


TET Technical Evaluation Team

TLD Thermoluminescent dosimeter

TRU Transuranic

WAC Waste Acceptance Criteria

WHPM Waste Handling Procedures Manual

WIPP Waste Isolation Pilot Plant

WM Waste Management

WMO Waste Management Operations 


\title{
DECONTAMINATION AND DECOMMISSIONING OF \\ 61 PLUTONIUM GLOVEBOXES IN D-WING, BUILDING 212 \\ ARGONNE NATIONAL LABORATORY - EAST: FINAL PROJECT REPORT
}

by

\author{
C.L. Cheever and R.W. Rose
}

\section{EXECUTIVE SUMMARY}

Since programmatic research funding had been phased out, the decontamination and decommissioning of 61 plutonium gloveboxes in nine laboratories in Building 212, Argonne National Laboratory-East (ANL-E), was proposed by ANL-E and funded by the Department of Energy (DOE). The gloveboxes had been used from the early 1960s to 1989 for research on nuclear reactor fuel development and for determination of properties of actinide metals. The decommissioning was to eliminate the risk of release of plutonium from the contaminated glovebox systems and to make the building space available for beneficial use. The project objectives were to remove the plutonium glovebox systems, decontaminate the laboratories to meet unrestricted use criteria, and dispose of the resulting radioactive waste. Both ANL-E employees and contractor services were used to perform the project.

The work started in November 1992 and the final radiological survey was completed in January 1996. The duration of the physical work was 39 months. Contractor equipment and services for the active-passive neutron assay of the gloveboxes, after they had been emptied and decontaminated, was important in providing assurance of proper radioactive waste classification. A total of $229 \mathrm{GBq}$ (61.9 curies) of radioactive waste was placed into 301 waste packages. The total volume of radioactive waste was 144.4 cubic meters $(5,157$ cubic feet $)$, weighing 54.2 metric tons (59.8 tons). Low-level radioactive waste was shipped to the DOE Hanford Site for waste disposal. Transuranic waste and mixed transuranic waste was placed in ANL-E on-site storage facilities.

The nine plutonium glovebox laboratories and associated interior corridors were surveyed following removal of the glovebox systems. The ANL-E Environmental, Safety, and Health Health Physics final radiological survey and a DOE verification survey provided reports supporting unrestricted use of the facilities, and the nine emptied laboratories were released by the DOE for unrestricted use.

The collective radiation dose to project personnel was 12.6 person-mSv (1.26 person-rem), about $29 \%$ of the collective dose forecasted at the start of the project. The total project cost was $\$ 6.9$ million. 


\section{INTRODUCTION}

Argonne National Laboratory-East (ANL-E) is a government-owned, contractor operated, multipurpose research facility located 25 miles southwest of downtown Chicago on 689 hectares $(1,700$ acres $)$ in DuPage County, Illinois, as shown in Figure 1.1. Building 212 is located in the central area of ANL-E, as shown in Figure 1.2.

The purpose of this project was to eliminate the risk of radioactive material release from the contaminated glovebox systems and to make the laboratories available for unrestricted use. The following work objectives were established:

- Identify and remove radioactive materials for return to ANL-E Special Materials control.

- Remove and package the radioactively contaminated materials and equipment from the gloveboxes.

- Decontaminate the gloveboxes to nontransuranic (non-TRU) levels.

- Size-reduce and package the gloveboxes and support systems.

- Document and dispose of the radioactive and mixed waste.

- Decontaminate, survey, and release the nine laboratories and corridor areas for unrestricted use.

Additional project objectives included:

- Minimize external radiation exposure, the intake of radioactive materials, and injury to personnel.

- Minimize the volume of radioactive waste, particularly of TRU and mixed waste.

- Minimize project costs within an As Low As Reasonably Achievable (ALARA) radiation exposure framework.

- Determine the most effective means for decontamination and for other project activities. 


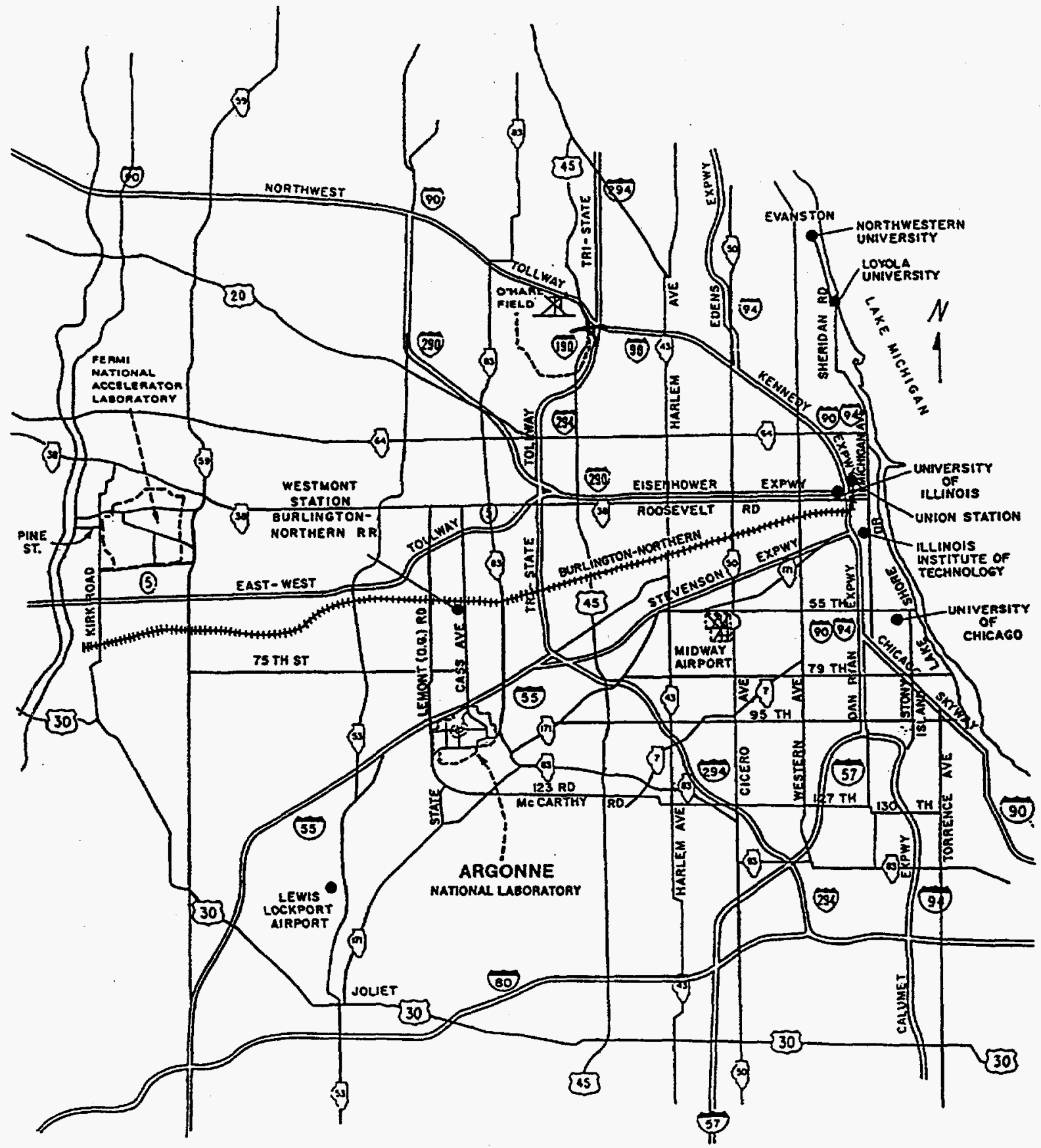

FIGURE 1.1 Map Showing ANL-E Location in the Greater Chicago Metropolitan Area 


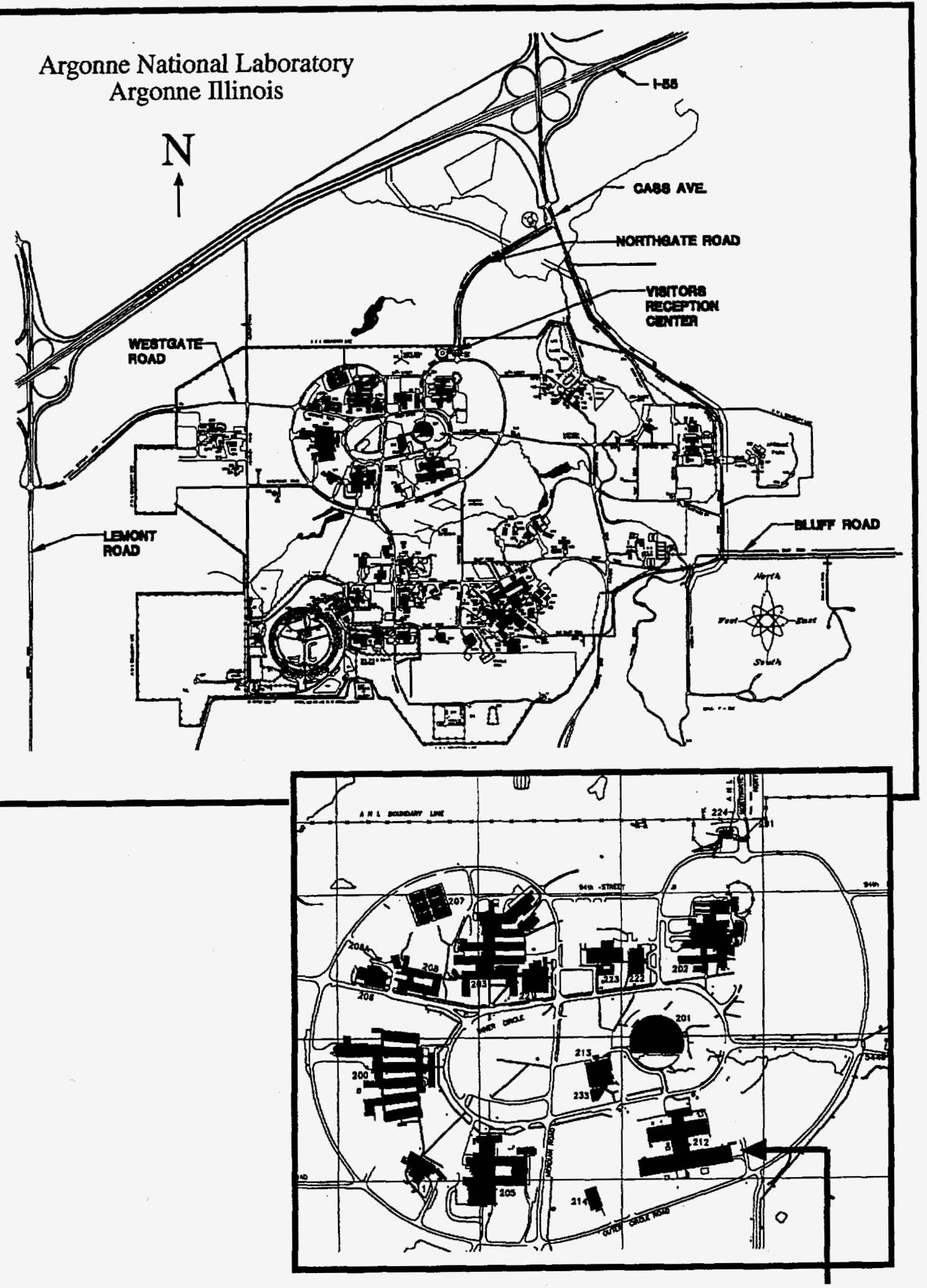

Bldg. 212

FIGURE 1.2 ANL-E Site Plan Showing Location of Building 212 
The decontamination and decommissioning (D\&D) project was proposed by ANL-E and was subsequently funded by the Department of Energy (DOE) for startup in November 1992, fiscal year (FY) 93. The project Final Status Radiological Survey was completed by ANL-E Environment, Safety, and Health (ESH) Health Physics in January 1996 (FY96). An independent verification survey was conducted by the Oak Ridge Institute of Science and Education (ORISE) for the DOE. This verification survey was completed in April 1996 and it was concluded that the nine project laboratories and interior corridors were acceptable for unrestricted use. Non-TRU radioactive waste was shipped to the DOE Hanford Site for waste disposal. Transuranic waste disposal shipments are presently on hold pending availability of a suitable DOE waste disposal repository. (All TRU waste is presently stored onsite at ANL-E.) 


\section{BACKGROUND: FACILITY HISTORY}

The plutonium glovebox research work began in Building 212 in 1960 for both applied and basic science research programs. The research included studies of different reactor fuel compositions and basic studies of actinide metals. The gloveboxes contained various equipment and instrumentation, including a lathe, milling machine, drill press, furnaces, polishing wheels, electron discharge machine, microscopes, etc. The glovebox systems were maintained under a nitrogen atmosphere with continuous monitoring for inward leakage of air (oxygen). After 30 years of research use, programmatic support for the research was no longer provided. The decision was made in 1989 to shut down the facility and to request funding for its decommissioning.

The glovebox systems had been designed and operated with the intent of confining the radioactive materials inside the negative pressure high efficiency particulate air (HEPA) filtered gloveboxes. The ventilation air pattern in the $\mathrm{D}$-Wing was from the perimeter offices to the perimeter corridors to the laboratories and from the interior corridors to the laboratories. Entrance into the laboratories did not require respiratory protection under normal circumstances. Radiation monitoring and protective clothing, however, were required. Glovebox gloves had to be replaced periodically due to deterioration and cracking from the effects of trace amounts of ozone and other possible chemical agents.

In 1963, a spillage of water and contaminated vacuum pump oil in laboratory DL-216, Building 212, had caused floor contamination which was successfully decontaminated.

The floor plan layout of Building 212, Energy Technology, is shown in Figure 2.1. The floor plans of the nine D-Wing plutonium laboratories are shown cross hatched in Figure 2.2 (first floor plan) and Figure 2.3 (second floor plan). Building 212, including all of the D-Wing offices, was occupied throughout the project. A photograph of D-Wing, Building 212, is shown as Figure 2.4. The project utilized functioning building administrative services including a PA system, maintenance and custodial services, locker rooms, lunch room, etc. Personnel adjacent to the project areas were given an orientation concerning project activities.

At the start of the project, the glovebox systems were in operational status, including oxygen monitoring to detect leakage of air into the nitrogen atmosphere of the gloveboxes. A schematic diagram of the gloveboxes once-through nitrogen system is shown as Figure 2.5.

Fifty-five gloveboxes were of extruded aluminum frame and aluminum base plate, two were of stainless steel frame and base plate, and four were of polyester/fiberglass frame and baseplate. All gloveboxes had O-ring gasketed safety glass windows. Some of the gloveboxes had special 


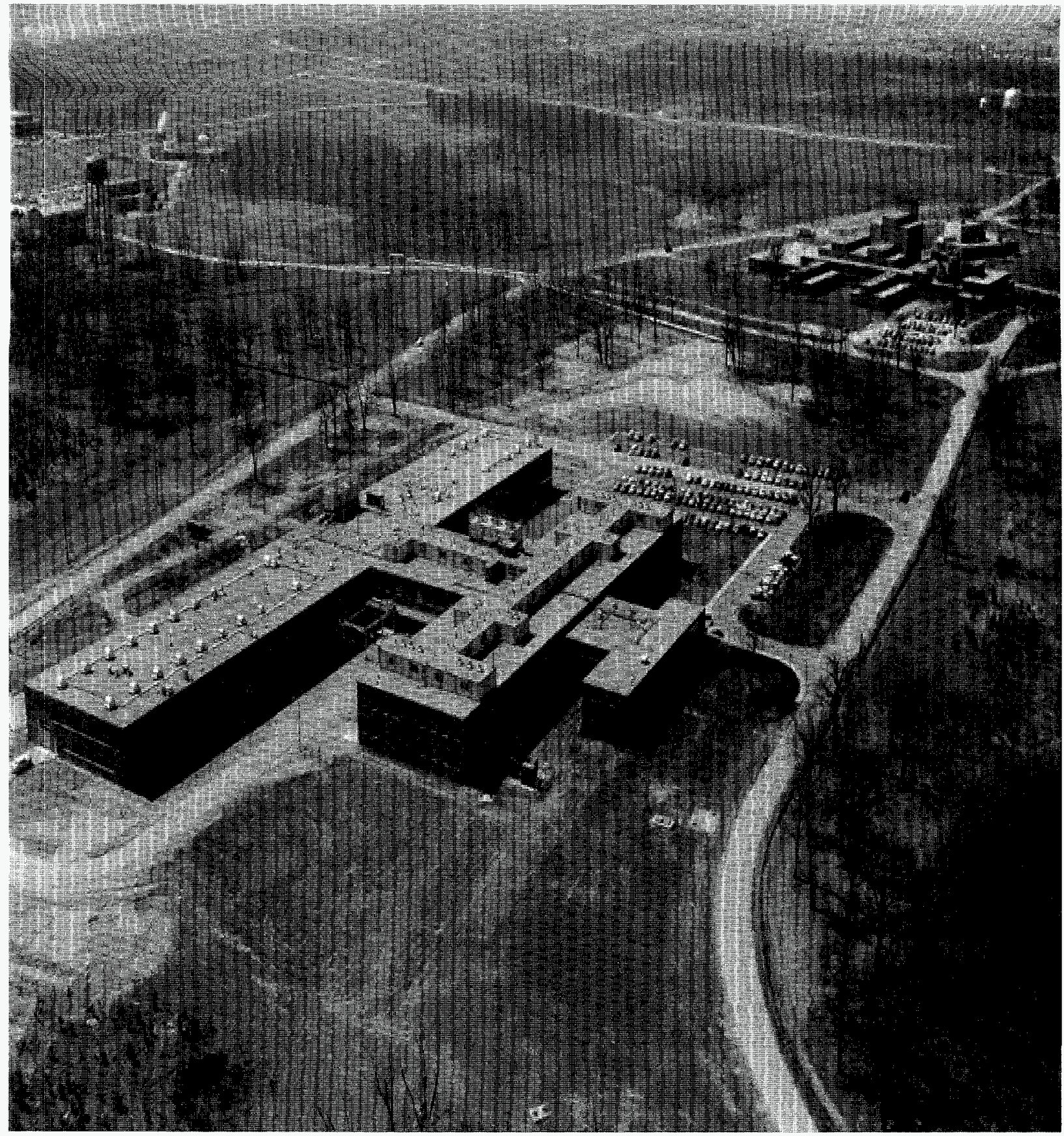

FIGURE 2.1 Building 212 (306-79-276) 


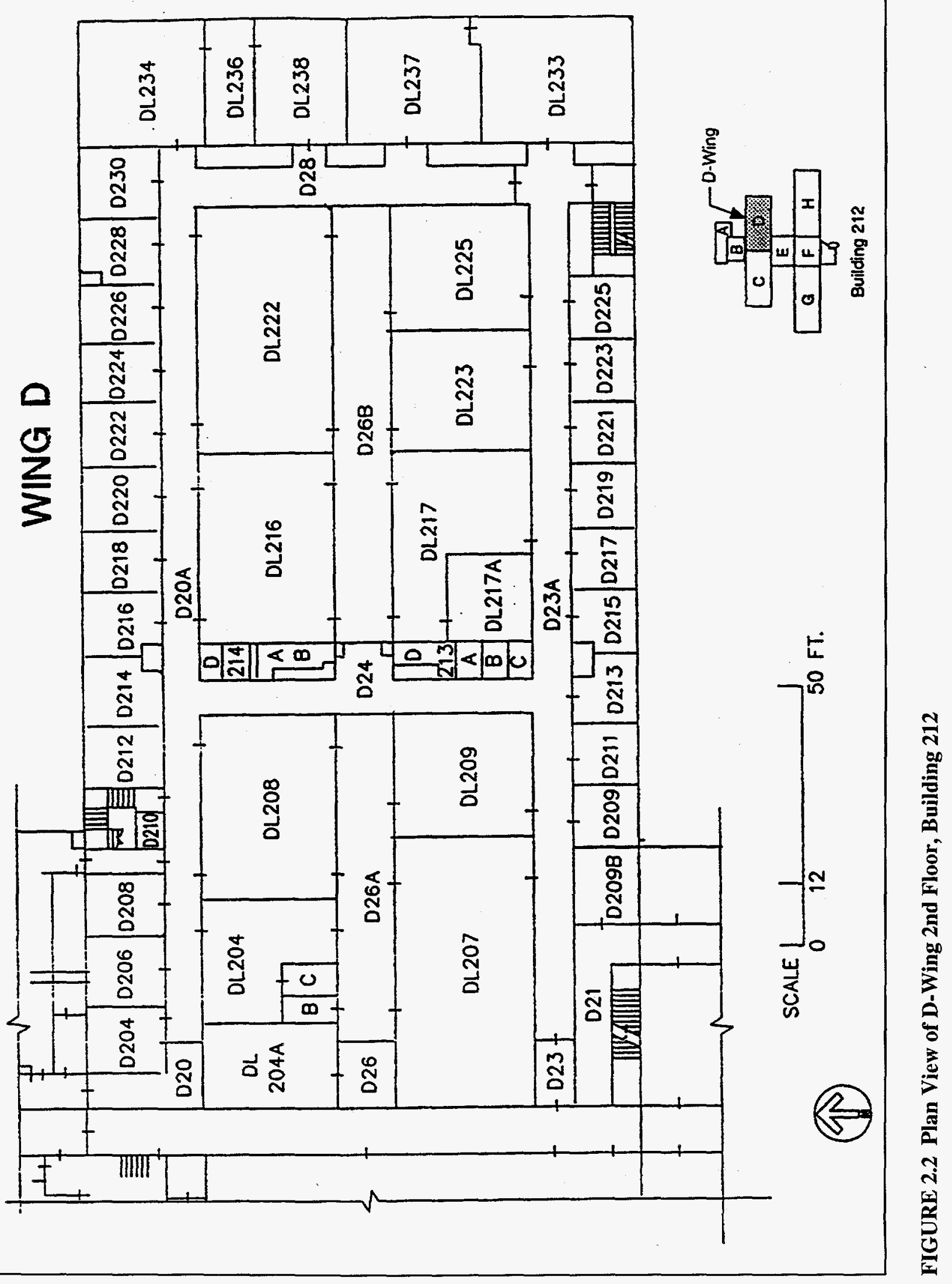




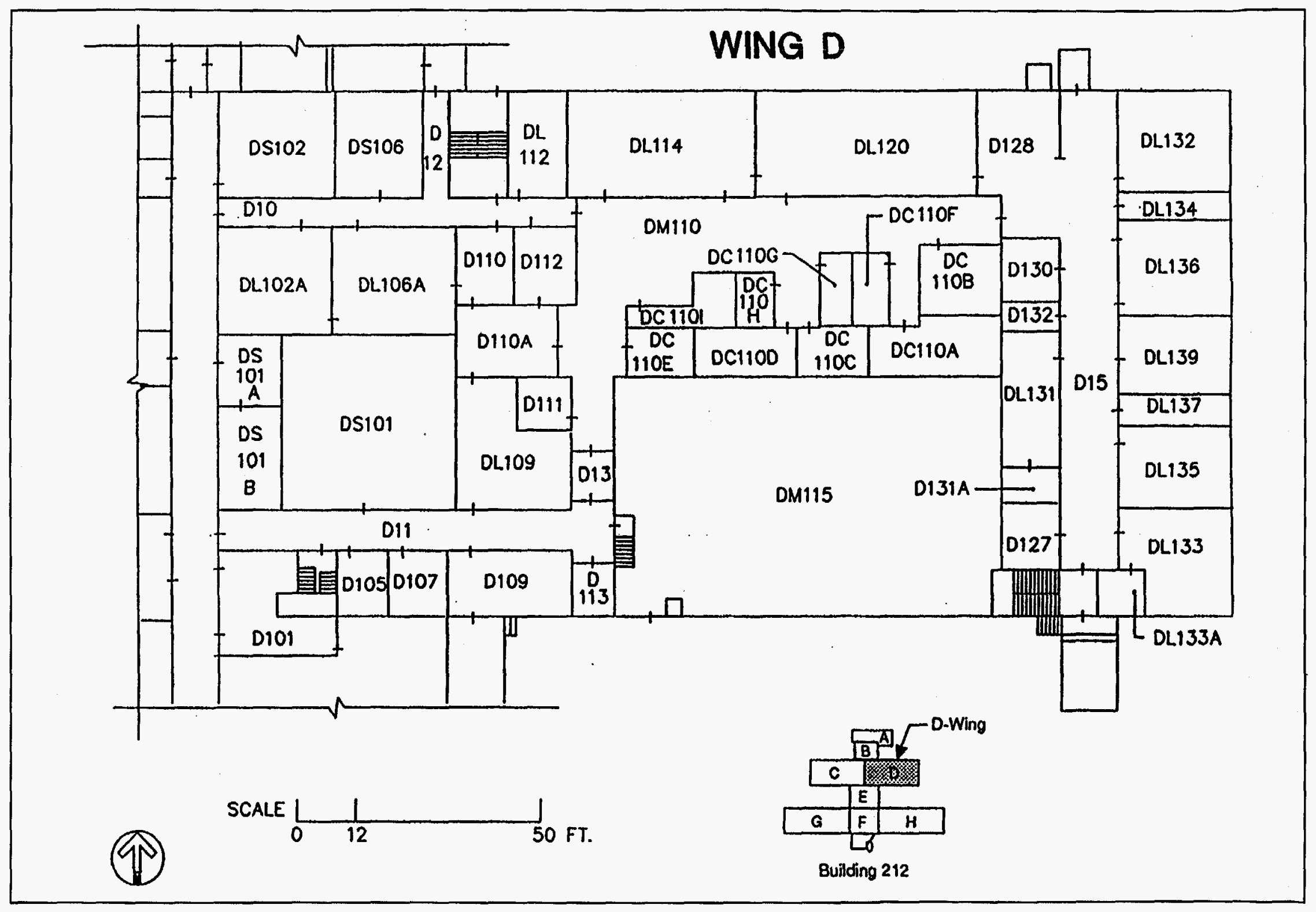

FIGURE 2.3 Plan View of D-Wing 1st floor, Building 212 


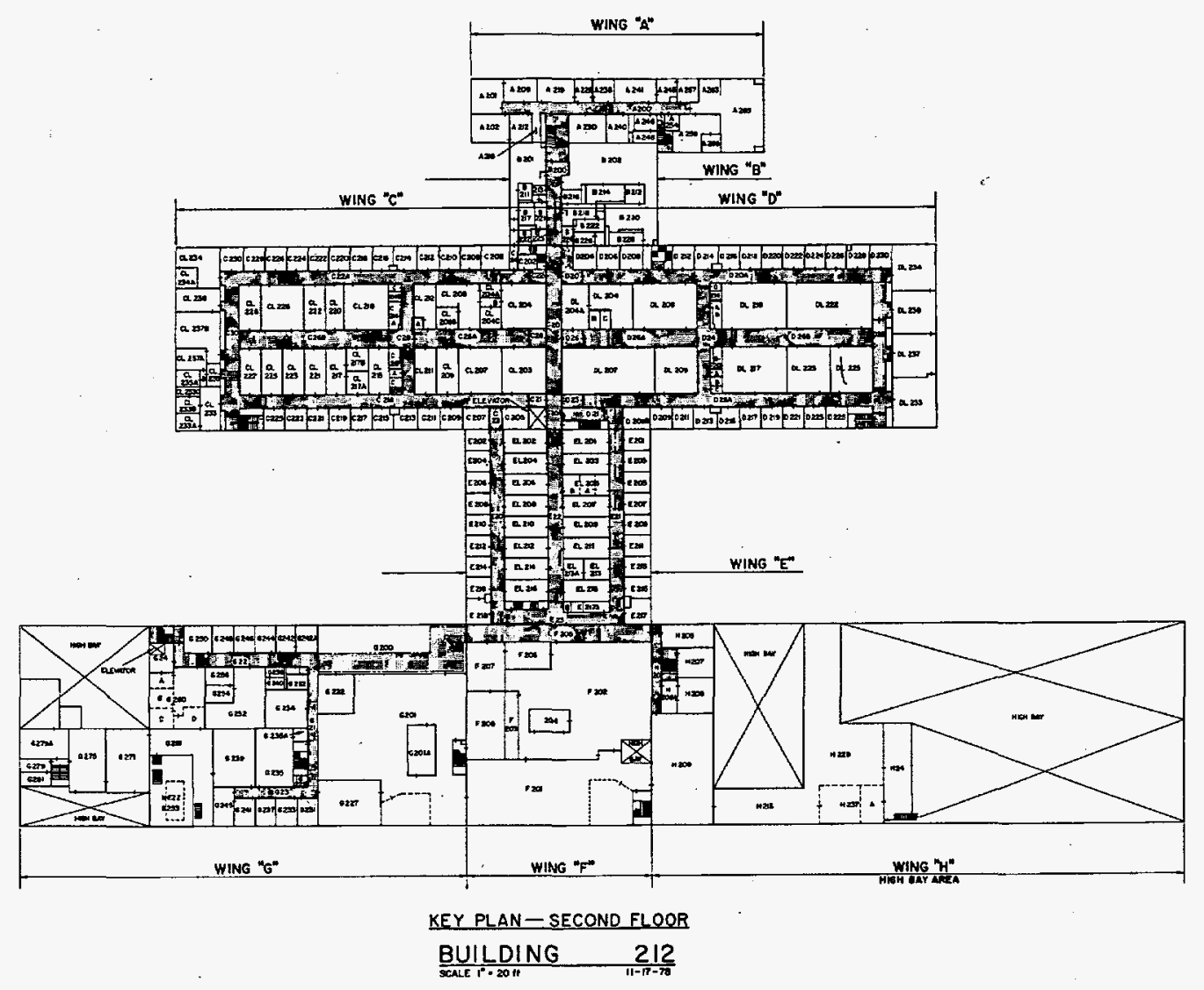

FIGURE 2.4 Building 212 Floorplan (202-251)

appendages, such as bottom and/or top extensions to accommodate internal equipment, side extensions, and utility connections such as vacuum and cooling water connections. Gloveboxes were mounted on unistrut frames to provide a suitable work elevation. The gloveboxes were grouped as follows:

Small: 20 gloveboxes nominally $101.6 \mathrm{~cm}$ (40 in.) long by $81.3 \mathrm{~cm}$ (32 in.) deep by $81.3 \mathrm{~cm}$ (32 in.) high.

Intermediate: $\quad 21$ gloveboxes nominally $101.6 \mathrm{~cm}$ or $195.6 \mathrm{~cm}$ (40 or $77 \mathrm{in}$.) long by 81.3 or $119.4 \mathrm{~cm} \mathrm{(32} \mathrm{or} 47$ in.) deep by 81.3 or $132.1 \mathrm{~cm} \mathrm{(32} \mathrm{or}$ 52 in.) high (none with all three dimensions minimum or maximum).

Large: $\quad 20$ gloveboxes nominally $195.6 \mathrm{~cm}$ (77 in.) long by $119.4 \mathrm{~cm}(47 \mathrm{in}$. deep by $132.1 \mathrm{~cm}$ (52 in.) high. 


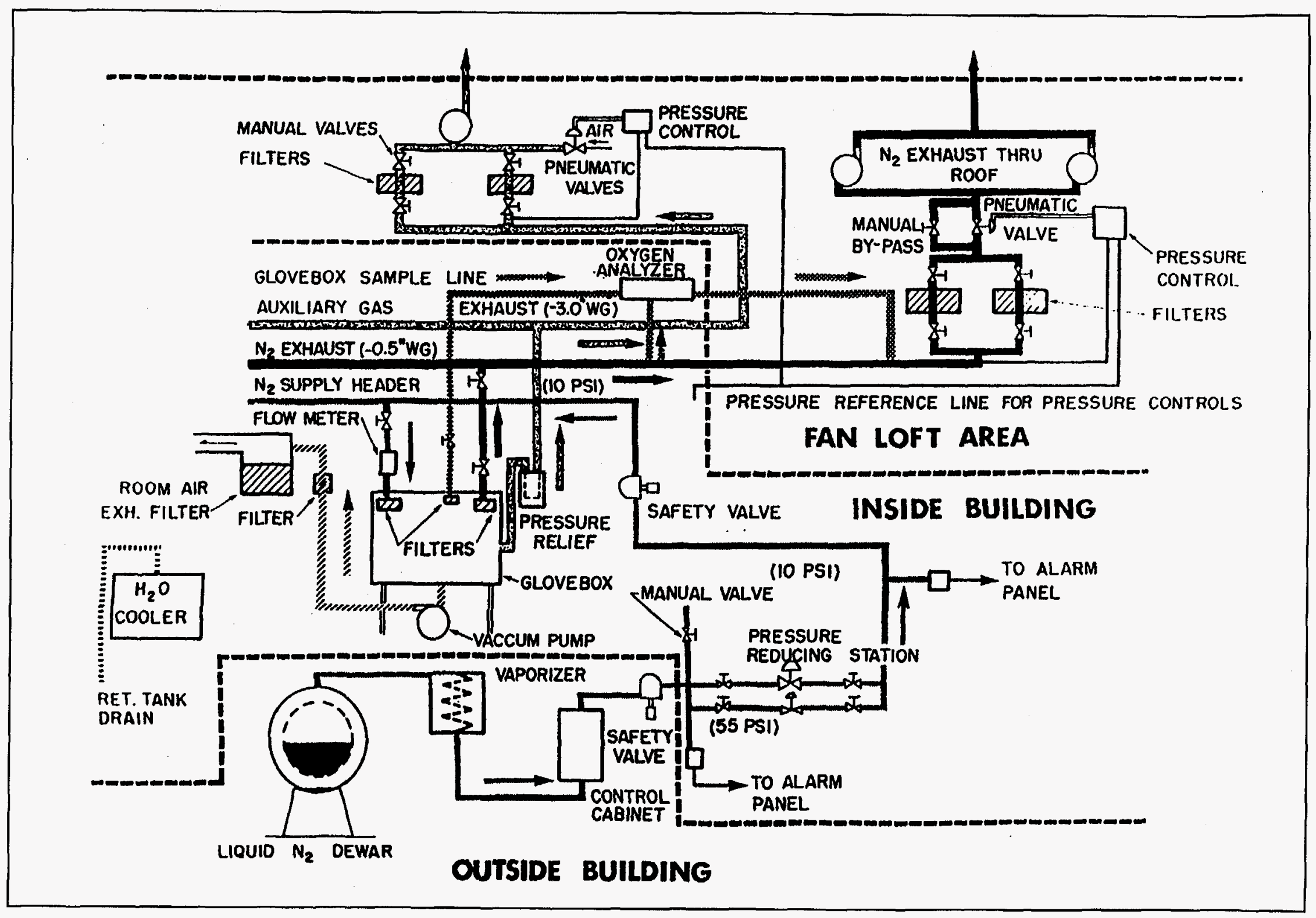

FIGURE 2.5 Once-Through $\mathrm{N}_{2}$ System for Plutonium Gloveboxes 


\section{DECOMMISSIONING OBJECTIVE AND WORK SCOPE (TECHNICAL APPROACH)}

The decommissioning objective was to remove and package the contents of the plutonium gloveboxes, decontaminate and assay the gloveboxes to attain non-TRU contamination levels, sizereduce and package the gloveboxes, survey and decontaminate the laboratories as necessary to release them for unrestricted use, and dispose of the radioactive waste.

The Work Scope (technical approach) to achieve the objective was divided into six major phases.

\subsection{PHASE 1}

In Phase 1, radioactive materials were removed from the gloveboxes, and radioactively contaminated materials that could be removed through glove ports or bag-out ports were removed. This work was accomplished by ANL-E personnel who were familiar with the glovebox systems and materials. The technical approach was to carefully itemize and record all materials bagged out and to package the TRU waste into DOT-17C fifty-five gallon drums. Full facepiece respiratory protection was used during the heat sealing of bags, cutting separation of heat-sealed bags, and loading of bags into the drums. This work was completed in February 1994.

\subsection{PHASE 2}

For Phase 2, it was decided, after an alternatives evaluation, that adequate resources were not available within ANL-E for the size-reduction and removal of large equipment, and the decontamination of the gloveboxes to non-TRU status. (The needed ANL-E resources had been committed to other work projects.) The removal of large equipment and glovebox decontamination work, along with subsequent assaying, glovebox size-reduction, waste packaging, piping removal, and radiological surveying, was contracted out. Contractor personnel provided health physics coverage with oversight by ANL-E Health Physics.

Hand tools, such as screwdrivers, wrenches, and pliers, were used for disassembly of most of the glovebox equipment. A Sawz-All saw and an abrasive wheel saw, both electrically powered, were used for size-reduction of large items, including a glovebox lathe, milling machine, and hydraulic press. Decontamination of emptied gloveboxes was by wet wiping with absorbent paper or rags wetted with nonhazardous aqueous liquid cleaners, such as $2 \%$ sodium carbonate, $4 \%$ sodium metasilicate, or $2 \%$ alkyl phenol ethoxylate. The cleaners were selected to meet the radioactive waste disposal site acceptance criteria. An electrically powered orbital sander with emery cloth was used 
on surfaces that remained above TRU levels after wet wiping. After sanding, the surfaces were again wet wiped. The contractor mobilized and started work on Phase 2, March 14, 1994. This work was completed in July 1994.

\subsection{PHASE 3}

In Phase 3, the emptied and decontaminated plutonium gloveboxes and drums of waste were assayed by contractor personnel using a leased Pajarito active-passive neutron assay system. This technical approach was utilized as it provided the most effective and sensitive methodology for assaying the gloveboxes. Subcontract specialists evaluated and reported the assay results. This work was started in July 1994 and was completed in October 1994.

\subsection{PHASE 4}

In Phase 4 the assayed gloveboxes were disassembled and packaged for disposal. Glovebox size- reduction work was carried out inside a HEPA filtered stainless steel paneled enclosure. The size-reduction enclosure was located in laboratory DL-207, Building 212, was maintained at a slightly negative pressure. Local exhaust ventilation and personal protective equipment was used during the hand-tool and power-saw cutting and disassembly of the gloveboxes inside the HEPAfiltered size- reduction enclosure. The glovebox size reduction work was started in February 1995 and was completed June 2, 1995.

\subsection{PHASE 5}

In Phase 5, the glovebox utility lines and false ceiling tiles were removed and packaged by contractor personnel for low-level radioactive waste (LLW) disposal. Floor tiles and floor tile mastic were removed and packaged for low-level radioactive waste disposal by ANL-E Waste Management Operations personnel. The LLW was shipped to the Hanford Waste Site for storage. A preliminary contamination survey of all laboratory and interior corridor floor areas was performed. The laboratory and interior corridor spaces were then decontaminated to meet the DOE unrestricted release criteria. This work was carried out by contractor personnel from June 5 to August 9, 1995.

\subsection{PHASE 6}

For Phase 6, ANL-E Health Physics conducted direct-surface-contamination measurements and removable-surface-contamination measurements of the laboratories and support area surfaces to determine compliance with DOE unrestricted release criteria. The technical approach was as 
follows: direct survey measurements and smear surveys of gridded room surfaces, radioactive analyses of collected paint and concrete surface material samples, direct survey measurements of exposed wall surfaces where paint had been removed, and direct and smear surveys of exhaust ventilation ductwork and electrical power strips. This work was conducted from October 1995 to January 1996. The summary report of survey results, with information on conformance with unrestricted release criteria, was completed 7 March, 1996. 


\section{WORK PERFORMED (ACCOMPLISHMENTS)}

\subsection{PROJECT MANAGEMENT}

The project organization chart is shown in Figure 4.1. The project manager was an ANL-E Technology Development Division, D\&D department, staff member. There was also a contractor project manager for the contractor personnel for phases 2 through 6 . The project was managed in accord with DOE Orders, with reporting to and oversight by the DOE. Weekly reports on project highlights and activities and monthly status reports were sent to the DOE. Off-normal occurrences were reported in accord with DOE Order 5000.3.

The project management strategy was to conduct the Phase 1 removal of materials from the gloveboxes using ANL-E technical personnel who had knowledge of the systems and the materials. An assessment of alternatives for proceeding with the D\&D work was then contracted out. The recommended preferred option for D\&D was as follows: to contract out for the removal and packaging of large equipment from the gloveboxes; decontamination of gloveboxes; and shipment of gloveboxes to the contractor facility for size-reduction, compaction, packaging, and disposal shipment. The preferred option was accepted as the way to proceed. However, it was subsequently learned that the contractor's license from the Nuclear Regulatory Commission did not include several of the radioisotopes present as contaminants in the gloveboxes. Therefore, size-reduction and packaging of the gloveboxes, was carried out by the contractor at the ANL-E Site. ANL-E had the responsibility for all shipments to approved waste sites. The glovebox D\&D tasks were contracted out by fixed fee competitive bid. Additional tasks were added under a time and materials contract. A glovebox size-reduction enclosure was erected in Building 212 for disassembly and packaging onsite rather than offsite. Onsite size-reduction represented a modification of the recommended preferred option.

ANL-E Waste Management Operations and Health Physics personnel were utilized for oversight and final decontamination of project areas. ANL-E Health Physics personnel conducted the final radiological survey.

\subsection{PROJECT ENGINEERING}

This project required only a small amount of detailed engineering, such as the design of local exhaust ventilation for usage inside the glovebox size-reduction enclosure for use in Phase 4. The enclosure was located in laboratory DL-207, Building 212 . The size-reduction enclosure was a procured item with specified size and features but with vendor-supplied engineering features. A plan view of the size-reduction enclosure is shown in Figure 4.2. The enclosure was $8.53 \mathrm{M}(28 \mathrm{ft})$ long, $3.66 \mathrm{~m}$ ( $12 \mathrm{ft})$ wide, and $2.44 \mathrm{~m}(8 \mathrm{ft})$ high with a 3.66 by $3.66 \mathrm{~m}$ (12 by $12 \mathrm{ft}$ ) entry air lock 


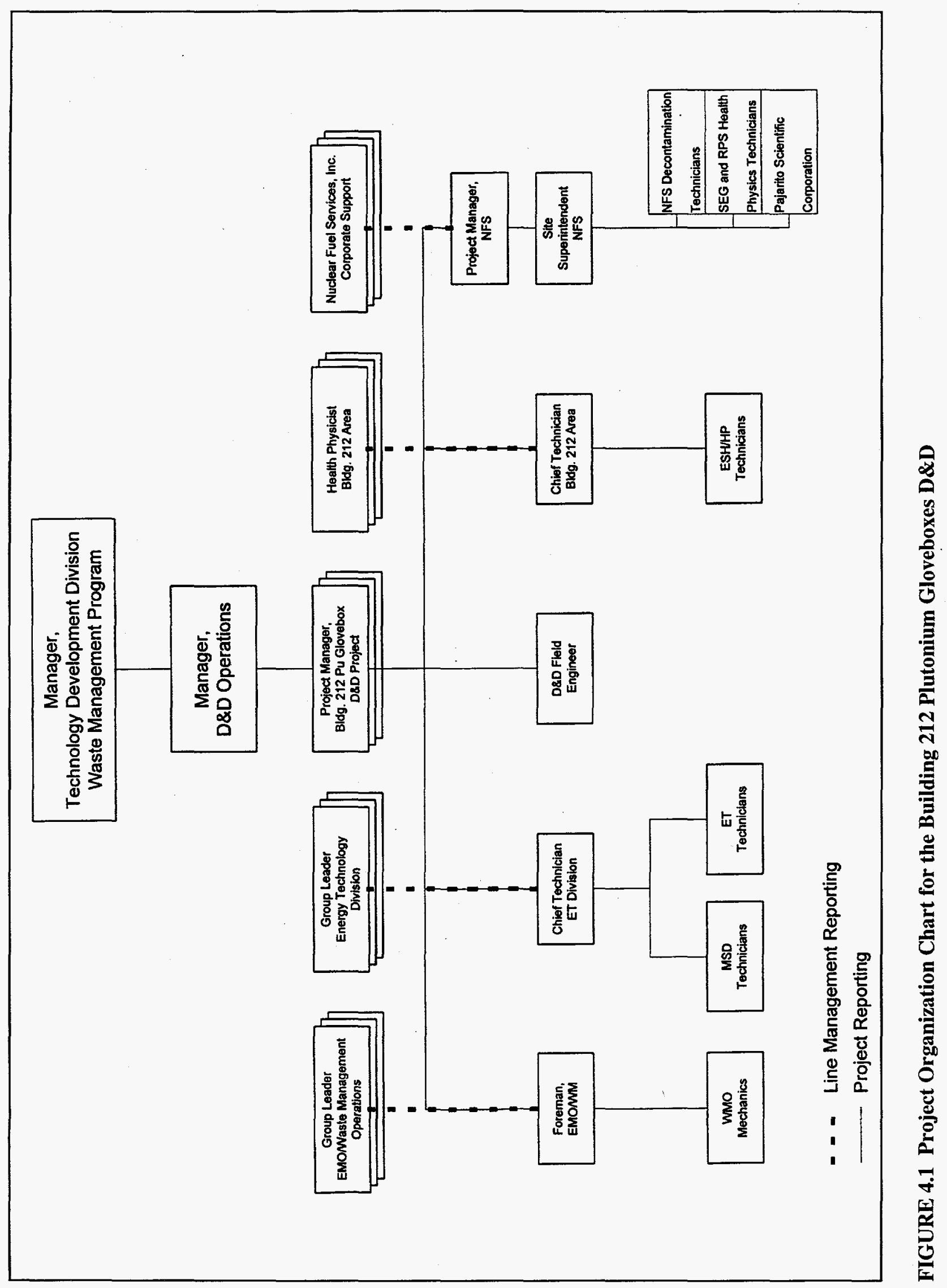




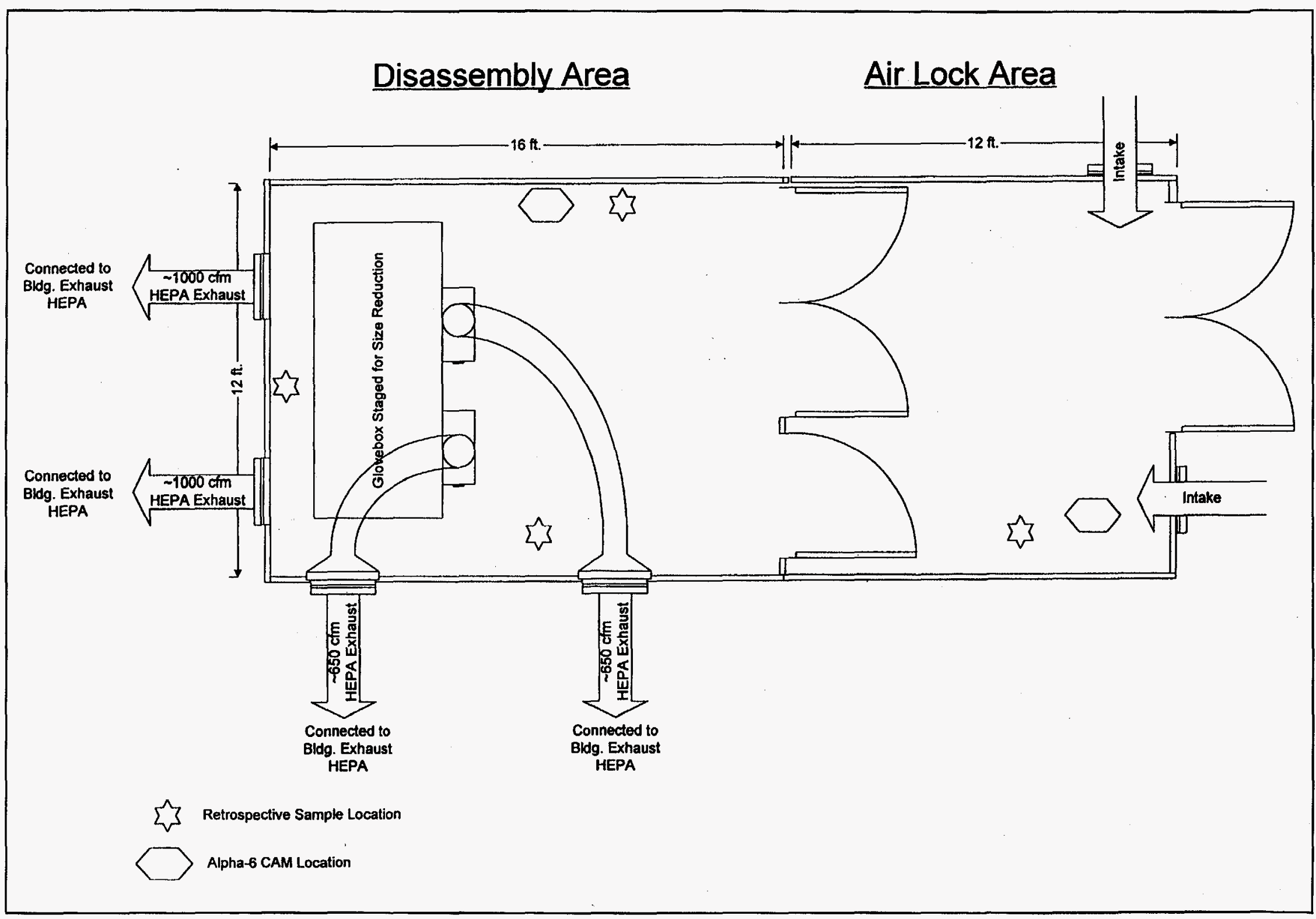


room and a 3.66 by $4.88 \mathrm{~m}$ (12 by $16 \mathrm{ft}$ ) disassembly room. Three 1.22 by $2.44 \mathrm{~m}$ ( 4 by $8 \mathrm{ft}$ ) transparent Lexan panels were available in the enclosure ceiling to allow laboratory ceiling lighting to supply lighting to the interior of the enclosure. No interior lighting in the enclosure was necessary as laboratory emergency lighting was also mounted above the enclosure ceiling level. The laboratory room floor of the enclosure consisted of a coat of strippable decontamination paint and three layers of $0.63 \mathrm{~mm}$ ( $25 \mathrm{mil}$ ) thick polyvinyl plastic sheets, with a polyester base fabric, over the decontamination paint. Five, 0.61 by $0.61 \mathrm{~m}$ ( 2 by $2 \mathrm{ft}$ ), Lexan plastic windows were located in the stainless steel panel walls. The HEPA filtered exhaust ventilation systems available in the laboratory room were connected to primary exhaust HEPA filters at the wall of the enclosure. This provided approximately one air change per minute in the size-reduction enclosure. The local exhaust ventilation within the size-reduction enclosure was custom designed by an ANL-E engineer. It was designed so that it could be positioned for disassembly and cutting operations so as to minimize the release of radioactive air contaminants into the size-reduction enclosure atmosphere. The exhaust was doubly HEPA filtered and discharged through a fan loft-exhaust stack.

A lifting hook was installed in the ceiling of the size-reduction enclosure disassembly room and was load tested with $1,428 \mathrm{~kg}(3,151$ pounds) prior to usage.

A HEPA filtered polyethylene sheet plastic tent was erected in laboratory DL-204, Building 212, for disassembly of glovebox exterior material, such as vacuum pumps and cooling water systems. Construction of the size-reduction sheet plastic tent for disassembly of glovebox cooling water systems and vacuum pump systems was based on field experience gained from previous ANL-E work. Room exhaust HEPA filters were connected to the tent enclosure. This system provided approximately 24.4 meters ( 80 feet) per minute air velocity through the entry door opening with the doors fully open for moving items into or out of the tent.

\subsection{CHARACTERIZATION}

There were several methods employed for characterization of the gloveboxes, glovebox contents, support equipment, and room surfaces, as follows:

- Samples of oil taken from the glovebox systems were analyzed for radioactivity by gross alpha, gross beta-gamma, alpha spectroscopy, and betagamma spectroscopy measurements by the ANL-E Analytical Chemistry Laboratory. Results were used to classify the oil as TRU or non-TRU radioactive waste.

- Dry smear samples were taken with Whatman \#1 (7 cm diameter) filter paper on the glovebox floor area at each workstation. These samples of a 7.6, 15.2, or $30.5 \mathrm{~cm}^{2}\left(0.25,0.50\right.$, or $\left.1.0 \mathrm{ft}^{2}\right)$ smear area, depending on the glovebox 
size, were analyzed using a combination of alpha and gamma spectroscopy techniques for isotopic radioactivity amounts. The isotopes identified were Cm-243, Am-241, Am-243, Pu-238, Pu-239, Pu-240, Pu-241, Np-237, U-235, $\mathrm{Pa}-233$, and Cs-137. These samples provided an indication of the amount and type of loose radioactivity in the gloveboxes.

- Alpha and beta-gamma surface contamination measurements were taken of the gloveboxes using portable radiation detectors. Alpha surface contamination surveys were performed by placing a detector probe inside a glovebox. The detector cord was threaded through a glove-port pouch which was then tape sealed. The contamination levels ranged up to $6.67 \times 10^{4} \mathrm{~Bq}$ $\left(4 \times 10^{6} \mathrm{dpm}\right) / 100 \mathrm{~cm}^{2}$.

- Baseline room surveys were carried out by ANL-E Health Physics personnel and subsequently by contractor personnel at the start of their work. The ANL-E survey was of all horizontal and vertical surfaces below the $2.44 \mathrm{~m}$ (8-ft) level. Both direct reading survey instruments and smear sampling were used. Instrumentation included alpha-beta-gamma scintillation detectors for surface contamination measurements; energy-compensated GM detectors to measure radiation fields, gas-flow and/or sealed gas probes; and scintillation detectors to measure alpha-beta surface contamination. Gross alpha-beta measurements were performed on smear samples using a gas-flow proportional counter. The surveys were conducted in August and September 1993.

Contractor baseline room surveys were carried out in March 1994, using instrumentation and techniques similar to those used by ANL-E. Findings were recorded on plan view sketches of the rooms and equipment.

- After removal of glovebox contents and decontamination, 61 gloveboxes and 165 fifty-five-gallon drums of radioactive waste were assayed using a leased Pajarito Scientific Corporation active/passive neutron assaying system. The results of the assays were evaluated by assay specialists using computer software. The assaying was accomplished during the period July through October 1994.

- Final room surveys for unrestricted release were conducted by ANL-E Health Physics personnel from October 1995 to February 1996. The surveys were of all room surfaces (floor surfaces, after floor tile and mastic had been removed, and of wall and ceiling surfaces). Direct survey measurements and analyses of smear samples and surface material samples were performed to assess levels of surface contamination. 


\subsection{ALTERNATIVES ASSESSMENT}

A formal assessment of project alternatives was contracted out at the end of the Phase 1 pouch-out of radioactive materials and equipment by ANL-E personnel. The contractor prepared a formal report including evaluation of various alternatives and the recommended alternative for proceeding with the work. (This report is listed in the references section as Reference 8.) Table 4.1 shows the glovebox D\&D assessment options and the option selected.

\subsection{PREPARATIONS}

Preparations included the following:

- Planning and assignment of project team members.

- Training of project personnel on glovebox systems, radioactivity control, safety items, and project requirements.

- Writing of project plans.

- Obtaining a required Illinois permit for air emissions.

- Baseline bioassay and whole body radioactivity measurements for project personnel.

- Arrangements for personal external dosimetry (whole body TLD badges and TLD finger rings)

- Scheduling periodic bioassay samples.

- Arrangements for lockers, showers, and personal protective clothing.

- Planning and obtaining required tools, equipment, waste containers, and office space.

- Writing of requests for proposals and contracts.

The Phase 1 work preparations involved assignment of ANL-E personnel with glovebox work experience for the identification and removal of accountable radioactive materials and the bag out of small items and equipment. The standard operating procedures and equipment used for the 
TABLE 4.1 Assessment of Glovebox D\&D Options

\begin{tabular}{cl}
\hline Code & \multicolumn{1}{c}{ Option } \\
\hline A & ANL-E Site Using ANL-E Staff \\
B & ANL-E Site Using Contractor's Staff \\
C & Contractor's Site Using Contractor's Staff \\
D* & ANL-E Site for Clean Up using ANL-E staff; Contractor Site for \\
& Size-Reduction using Contractor's Staff \\
E & Glovebox Disposal - Untreated \\
\hline
\end{tabular}

* Selected Option. This was later changed to the ANL-E site for size-reduction.

glovebox research work were used in the Phase 1 work. Arrangements were made for locker/shower room usage, for protective clothing, orientation training, radiation worker training, health physics coverage, office assignments (as needed), dosimetry and whole body counting, waste containers, and project supervision oversight. During the Phase 1 work it was recognized that having two separate project-controlled work access areas, for the D-Wing, second floor, was inefficient. Arrangements were made to consolidate into a single controlled access work area by partitioning off a transverse corridor and relocating the entry-exit hand and shoe monitoring and protective clothing stations.

Phases 2, 3, 4, 5, and 6 were contractor work phases and required plans and office space assignments for contractor personnel. A staging area was assigned for contractor sea-land containers for storage of equipment, tools, and waste containers. A contractor Health and Safety Plan was reviewed and approved and other contractor plans and procedures were reviewed and commented upon by ANL-E. The orientation, training, dosimetry, and whole body counting (similar to that for ANL-E personnel), were provided for contractor personnel. ANL-E project plans incorporated project management, health physics, and safety oversight of contractor operations.

Known radioactive sources were used for equipment calibration checks for assaying work. This required arrangements for ANL-E to accept contractor owned radioactive sources at the ANL-E entrance post to bring them to the onsite use location.

ANL-E was responsible for disposal of both ANL-E and contractor packaged and documented waste. Preparations for waste handling included NEPA documentation review and assignment of space for staging TRU waste drums. TRU waste is to be staged at ANL-E pending the opening of a DOE offsite TRU waste disposal facility and availability for acceptance of ANL-E TRU waste. 


\subsection{DECOMMISSIONING OPERATIONS}

The bag-out of equipment and materials through $20.3 \mathrm{~cm}$ ( 8 in.) diameter glove ports and $40.6 \mathrm{~cm}$ (16 in.) diameter materials bag out ports was carried out by ANL-E personnel. As this work progressed there was a search of the gloveboxes for accountable radioactive materials. The accountable materials were bagged out and returned to the Special Materials department.

Figures 4.3 and 4.4 show plutonium gloveboxes prior to the start of decommissioning operations.

Preparations for bag out of glovebox materials and equipment are depicted in Figures 4.5 and 4.6. To reduce the risk of punctures or tears due to sharp edges, selected items were taped, or wrapped and then taped, prior to bag out.

The bag out of TRU waste materials and equipment from plutonium gloveboxes is shown in Figures 4.7 and 4.8. The TRU waste was bagged into 20 mil PVC bags which were sealed with a three-twist taped seal and a triple dielectric heat seal beyond the twist/tape seal. The three dielectric heat seals were to prevent bag atmosphere and contamination from being released during handling of the bags. The middle heat seal was cut down the center to free the loaded bag from the glovebox part. This left one-and-a-half heat seals on the bag and one-and-a-half on the bag end covering the glovebox port. The cut ends were then taped.

Bags were loaded into the 110 mil rigid polyethylene drum liners with the seals upward. This was so that the space between the twist seals and the heat seals could be readily punctured subsequent to drum loading. (A punch hole was made between the twist seal and the heat seal to allow possible pressure release.) These operations required the usage of full facepiece HEPA filtered respirators by personnel who had received respirator training.

The materials and equipment were bagged out as TRU waste and loaded into DOT-17C galvanized steel drums, as shown in Figure 4.9. The lids for the 110 mil polyethylene rigid liners had at least a $0.95 \mathrm{~cm}(0.375$ in) diameter vent hole in the lid. All TRU waste drum lids had certified Nucfil vent filters which had passed a 0.3 diatyl phthalate micron (DOP) aerosol efficiency test. Note: the earliest drums used were non-galvanized DOT-17H drums. The bagged TRU waste in these drums were not repackaged into DOT-17C galvanized drums since the DOT-drums met the DOE revision 4 WIPP WAC. However, if a future waste acceptance criteria requires packaging in DOT 17-C galvanized drums, the waste in the DOT-17H drums will be transferred into these containers prior to shipment.

Equipment that was too large for bag-out was size-reduced using hand tools or electric saws. Disassembly of plutonium glovebox equipment is shown in Figures 4.10 and 4.11. All 


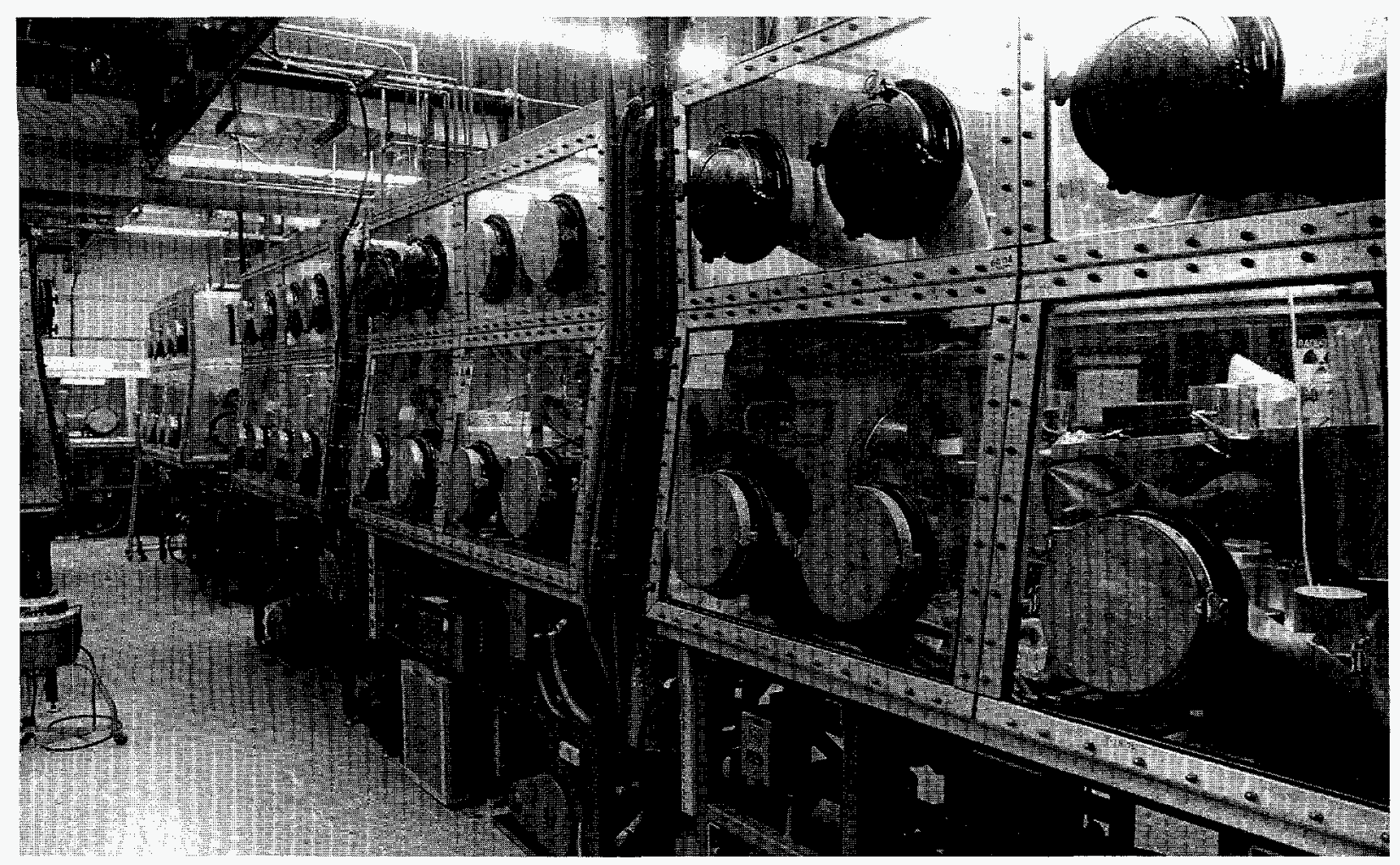

FIGURE 4.3 Plutonium Gloveboxes Prior to Decommissioning (6954K \#27)

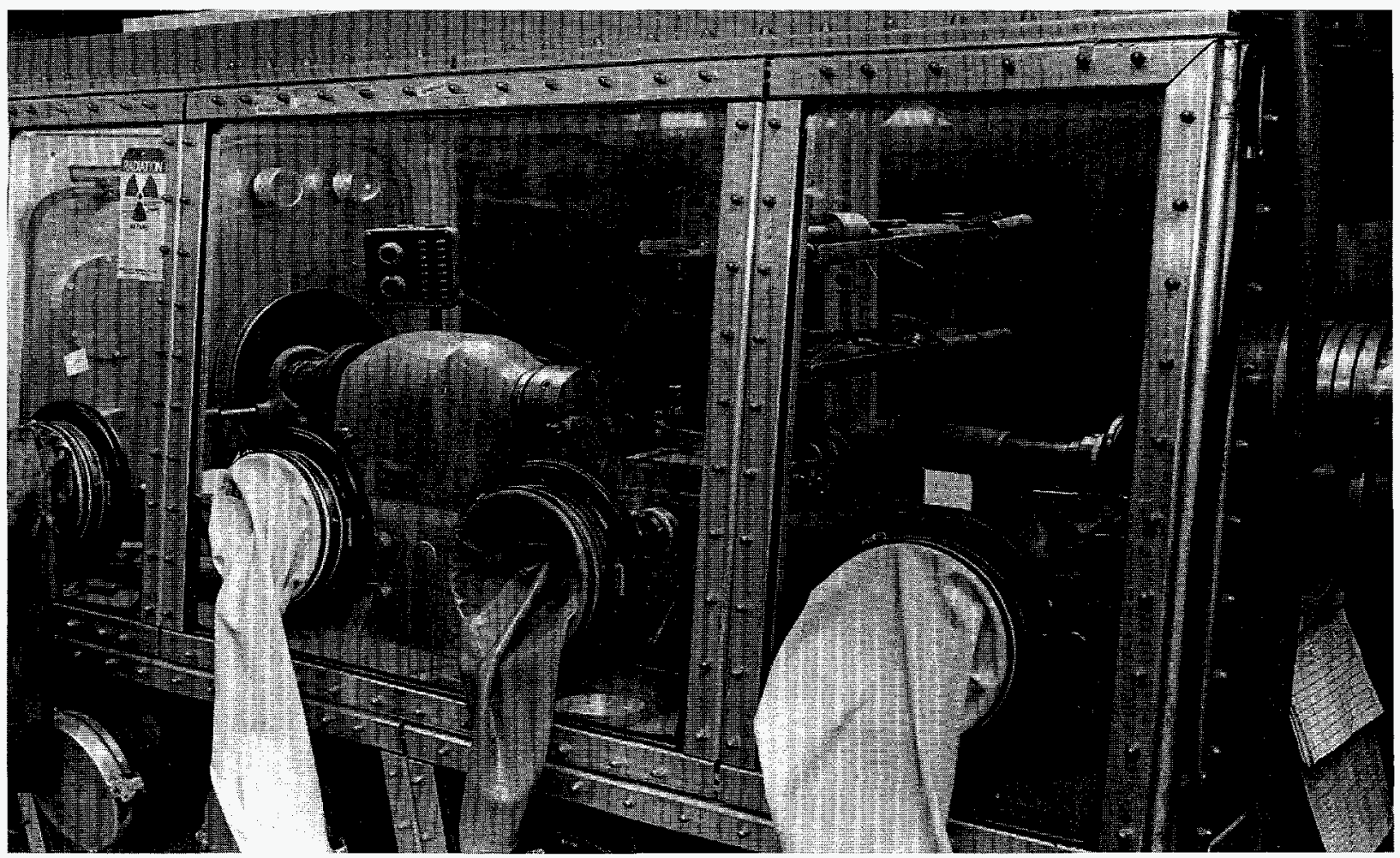

FIGURE 4.4 View Inside Plutonium Glovebox Prior to Decommissioning (6954K \#24) 


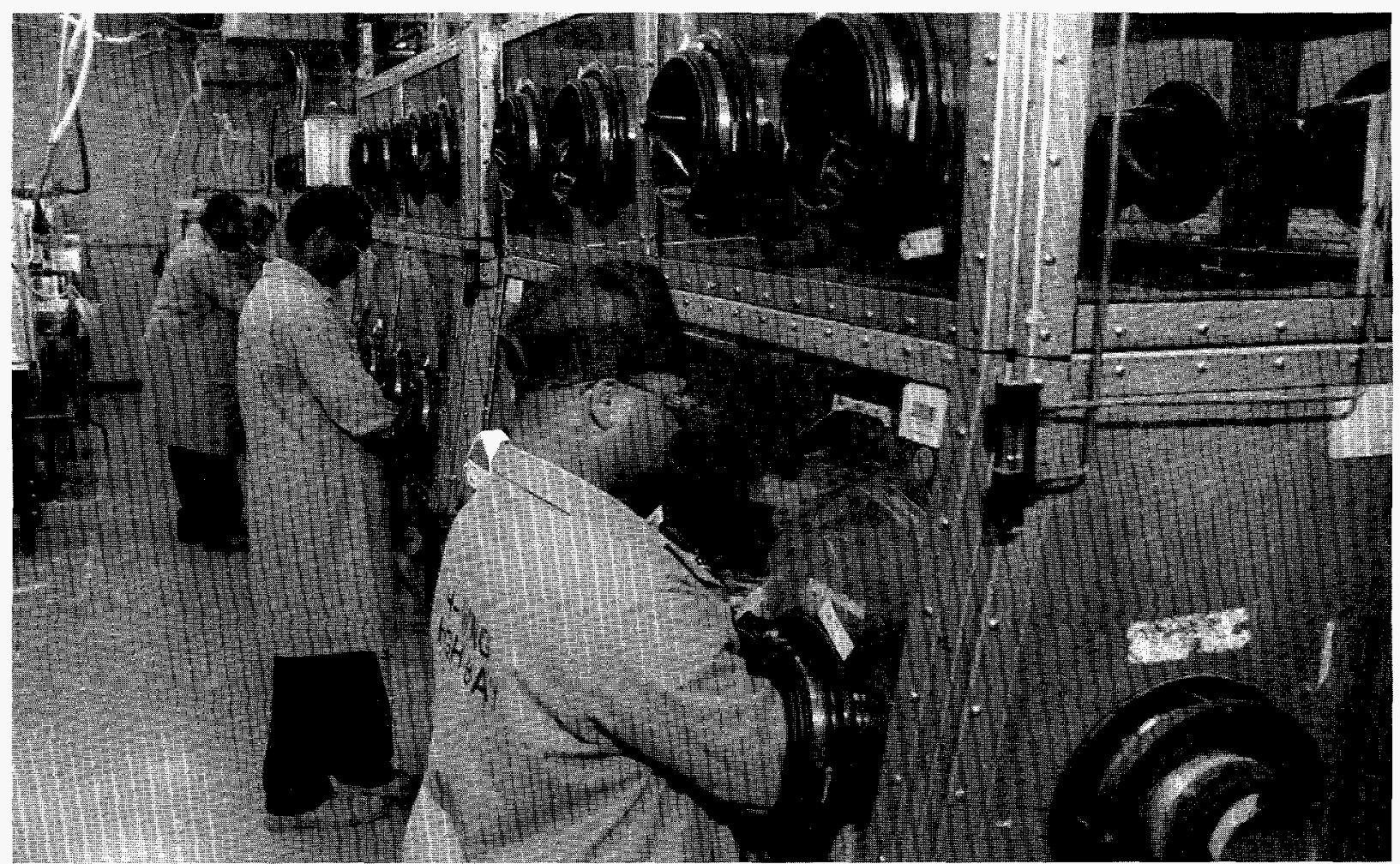

FIGURE 4.5 Preparing Disassembled Plutonium Glovebox Equipment for Bag Out (15494K \#18)

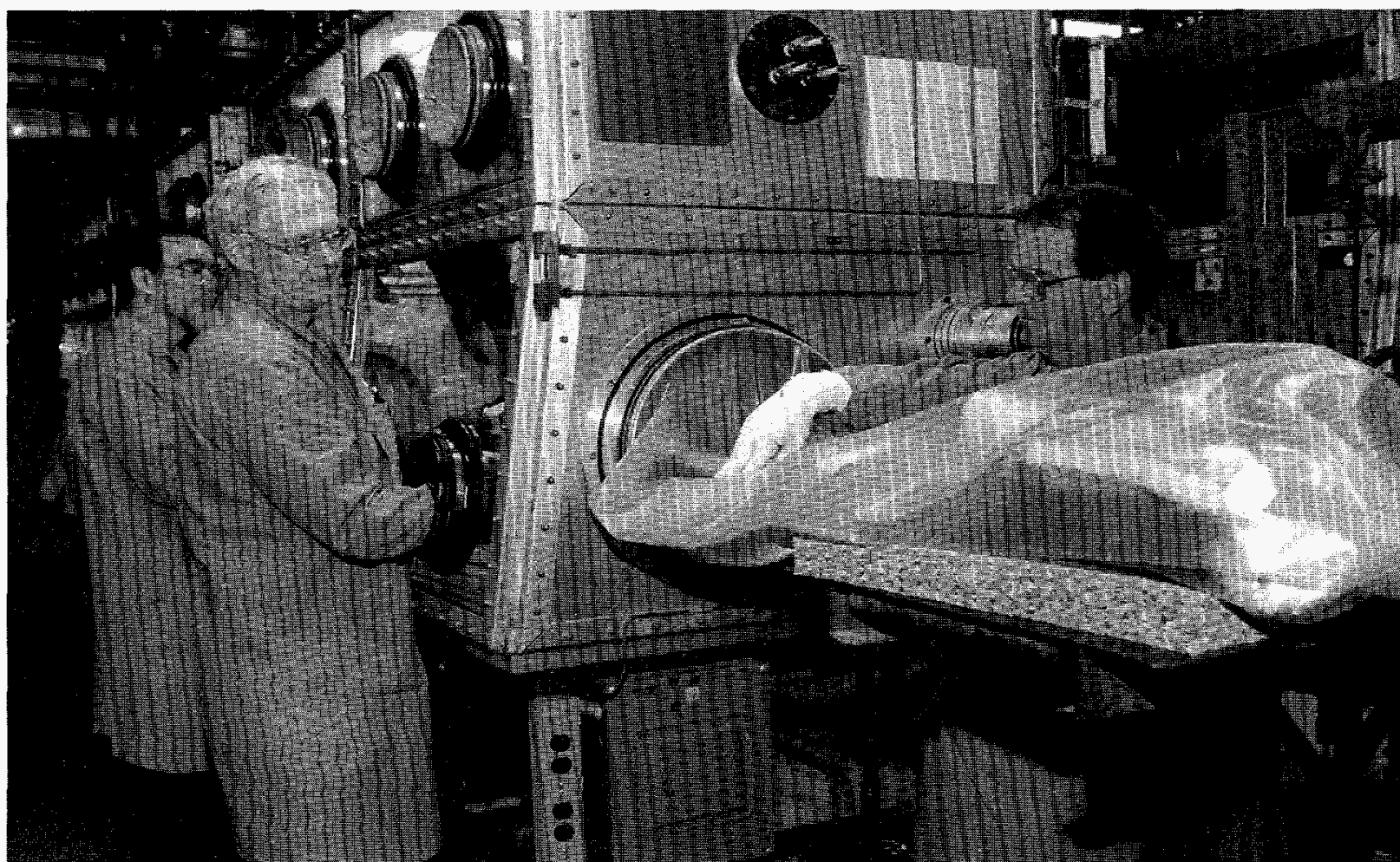

FIGURE 4.6 Preparing for Bag Out of Size-Reduced Equipment in a Plutonium Glovebox (15495K \#4) 


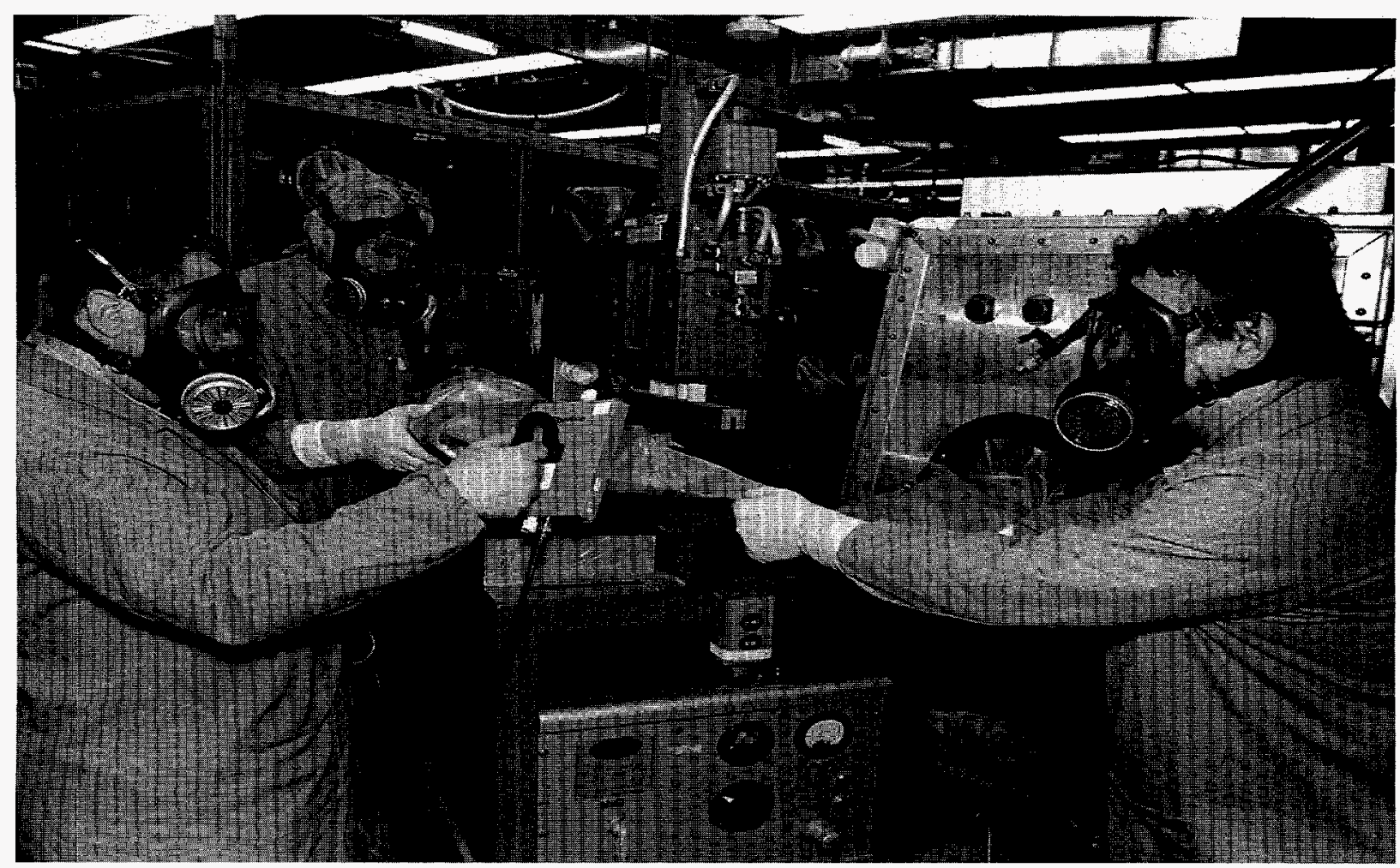

FIGURE 4.7 Bag Out of Size-Reduced Equipment from a Plutonium Glovebox (14478 \#17)

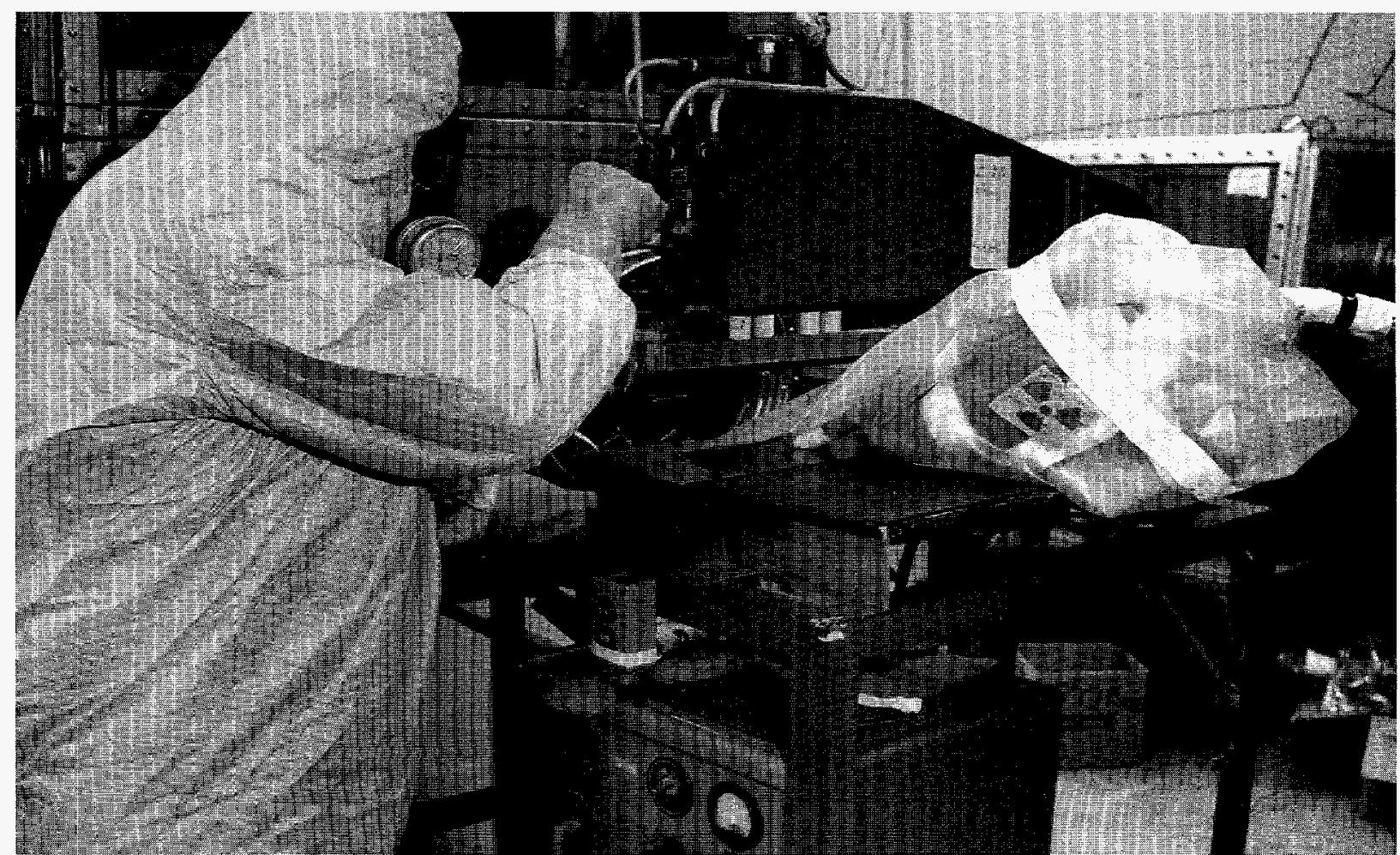

FIGURE 4.8 Heat Sealing of Bag of TRU Radioactive Waste (15494K \#13) 


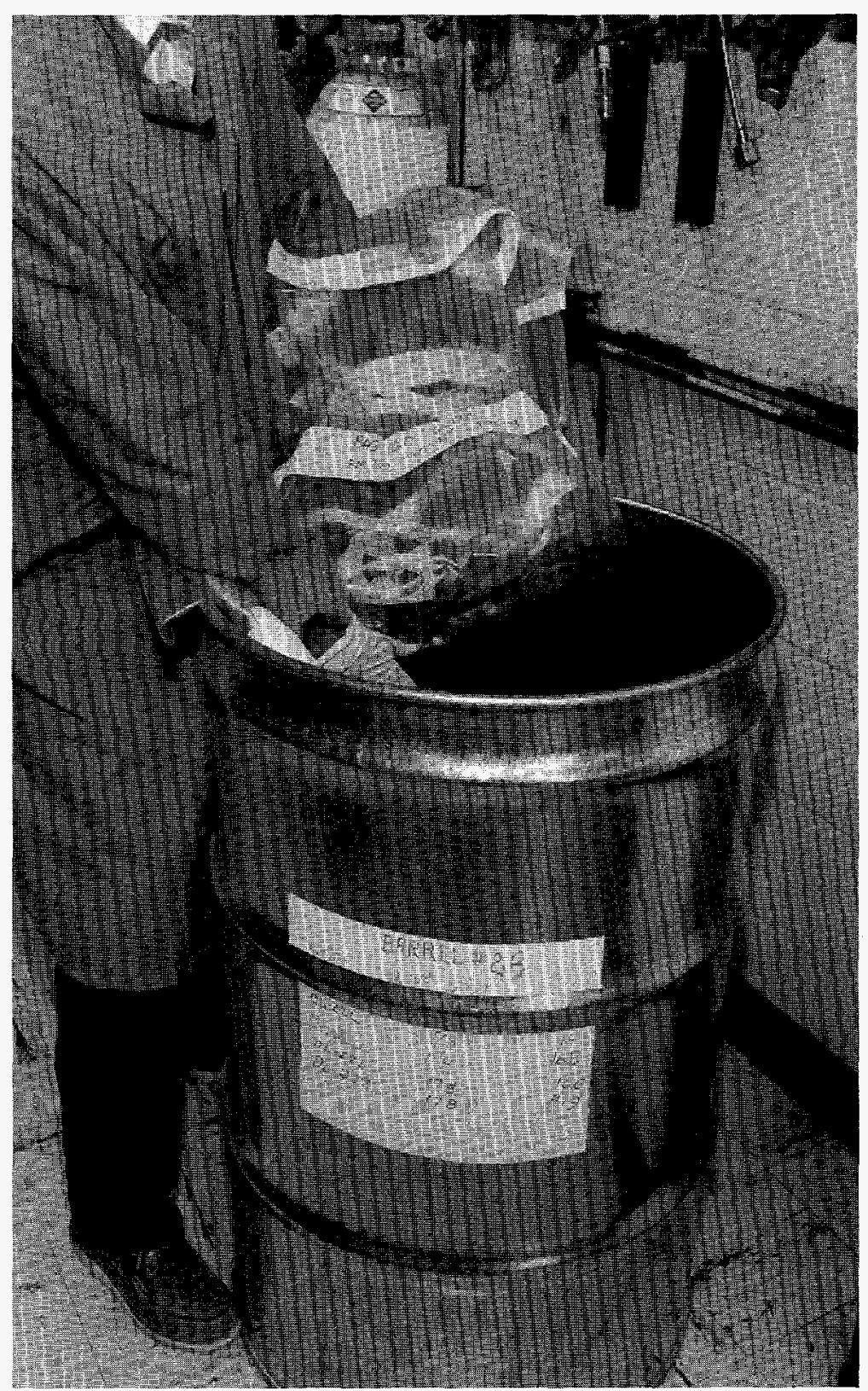

FIGURE 4.9 Loading Bagged Glovebox Materials into a Waste Drum (15495K \#9) 


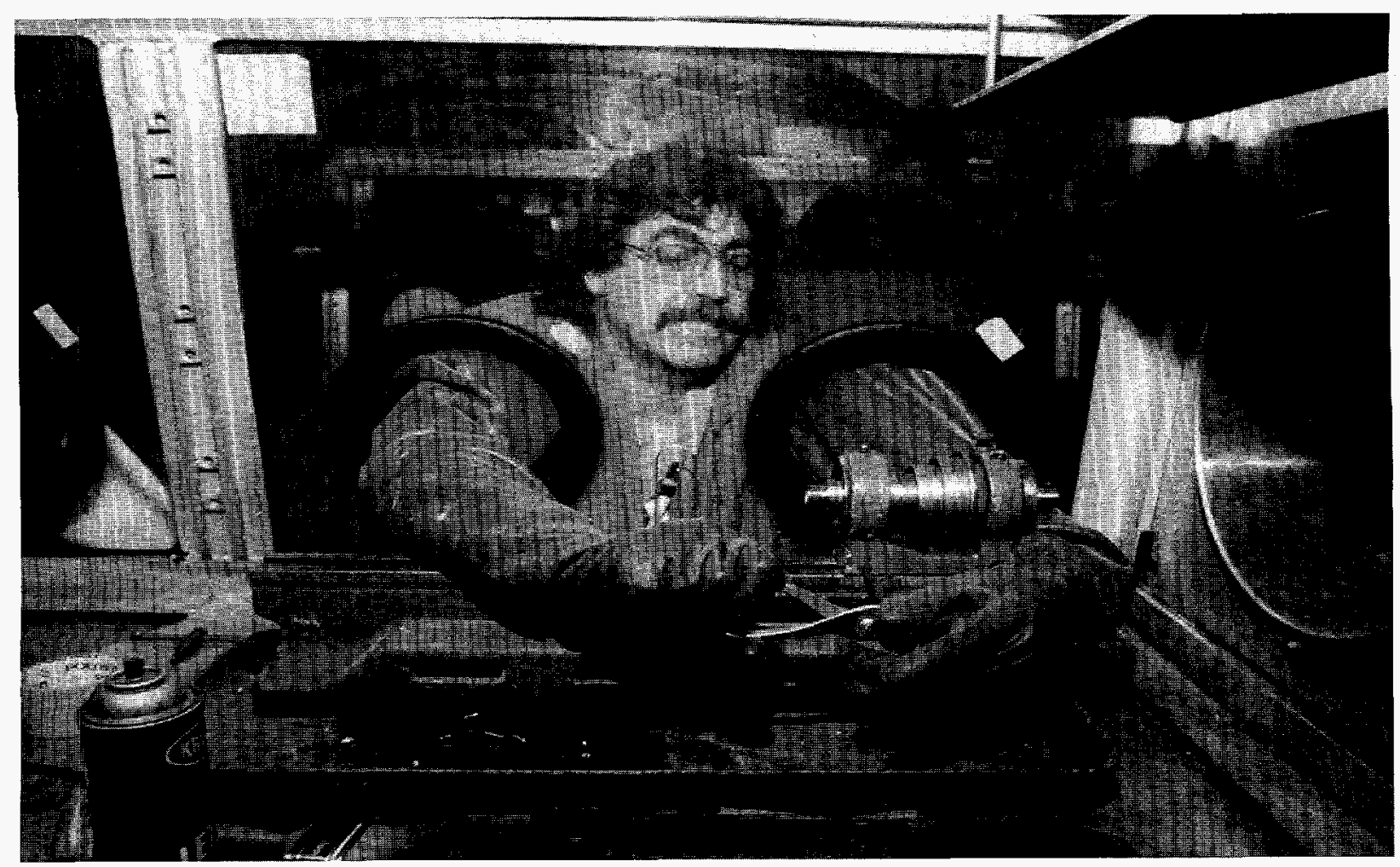

FIGURE 4.10 Disassembly of Plutonium Glovebox Equipment - Close-Up (16811K \#6A)

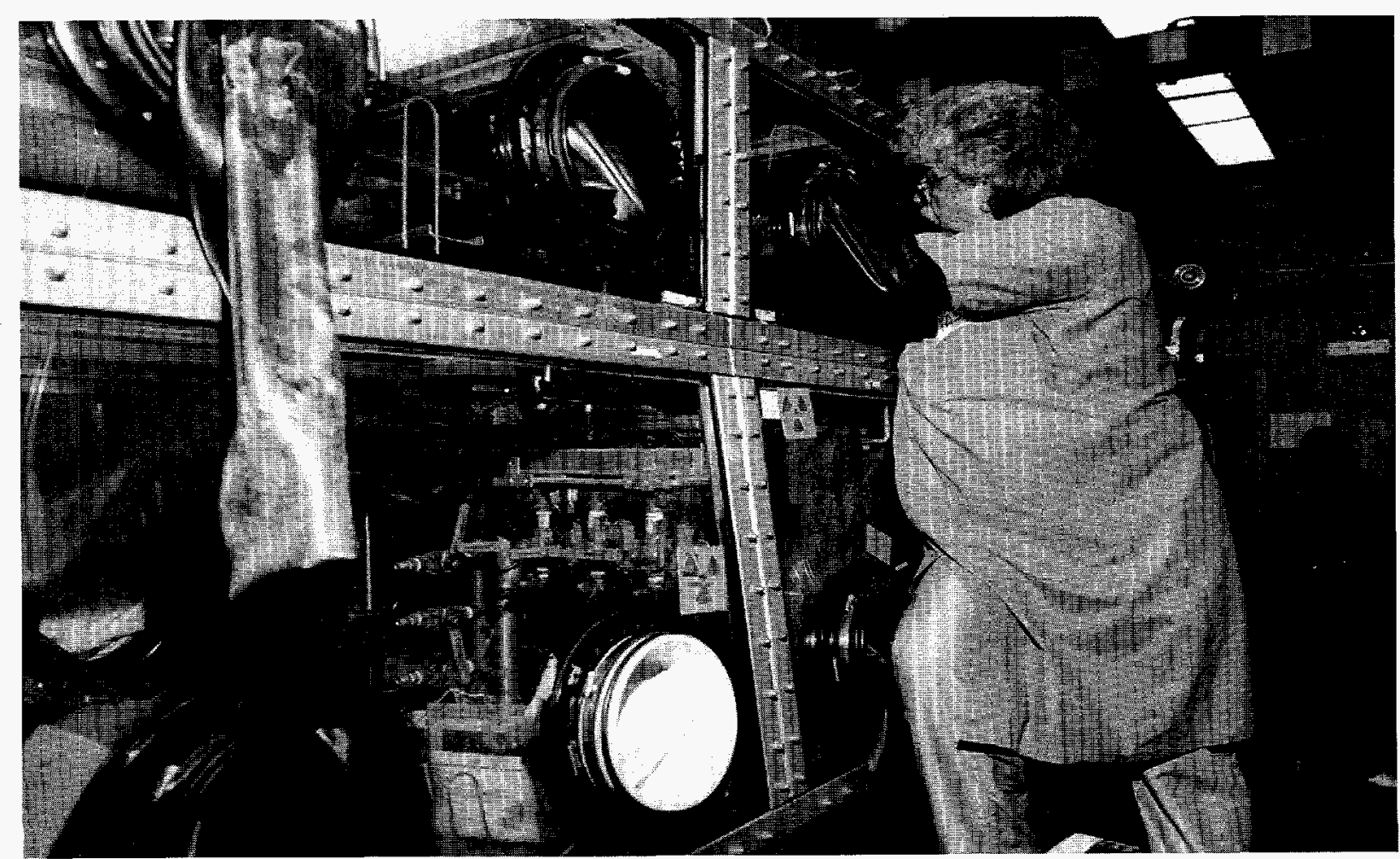

FIGURE 4.11 Disassembly of Plutonium Glovebox Equipment (16810K \#21A) 
glovebox liquids were converted to solid waste by mixing with plaster of paris, zinc powder, or Petrosorb material, as appropriate. Hazardous materials, such as lead, were bagged out separately, packaged, labeled, and documented as mixed waste.

External equipment connected to the gloveboxes was internally contaminated. Therefore, it was disassembled and prepared for waste packaging inside the HEPA exhaust filtered polyethylene sheet plastic tent. Personnel entered the tent wearing full Tyvek protective suit clothing and full facepiece HEPA filtered respirators. Size-reduced external equipment included eight water cooling systems and 34 vacuum pump systems (mechanical and diffusion types). The cooling water tanks were cut open using an electric drill and an electric Sawz-All saw. Surveying of the disassembled external equipment showed that it was LLW. The LLW was placed into a wooden bin liner. Disassembly and surveying of mechanical vacuum pumps from plutonium glovebox systems is shown in Figure 4.12. Figure 4.13 shows surveying of the bagged LLW after placement into a bin liner.

In July 1995 Pajarito active-passive neutron assaying equipment was mobilized in Laboratory DL-222, Building 212, for the assaying of the emptied and initially decontaminated plutonium gloveboxes. The assay work was carried out by contractor personnel and the results were transmitted to subcontractor specialists for computerized determination of the TRU content of the gloveboxes. The Pajarito assay enclosure, with a glovebox being positioned, is shown in Figure 4.14. Assaying of gloveboxes was completed in August 1995 and a decision was made to extend the use of the assay equipment in order to assay waste drums. Assaying of 165 waste drums was completed in October 1994 and the Pajarito equipment was demobilized the week of November 7, 1994. Operating personnel wore monthly film badges during assaying of gloveboxes and radioactive waste drums and, in all cases, the measured thermal, epithermal, and fast neutron doses were less than the $100 \mathrm{uSv}$ (10 mrem). Therefore, no positive exposures were reported.

In October and November 1994 a stainless steel paneled enclosure was assembled and tested in laboratory DL-207 for size reduction of decontaminated and assayed plutonium gloveboxes. Glovebox size-reduction procedures were written; an in-depth safety review was conducted; radioactive waste packages were transferred to storage areas; and local exhaust ventilation for glovebox size-reduction work was designed, fabricated, and installed during November 1994 to March 1995. The glovebox size-reduction work was planned to be carried out in four steps starting with the least contaminated gloveboxes and ending with the most contaminated gloveboxes. Lapel air filter samples, fixed location air filter samplers, and a portable alpha continuous air monitor (CAM) were provided for usage inside the glovebox size-reduction enclosure. It was planned to survey and decontaminate the glovebox size-reduction work area whenever contamination levels exceeded $33.3 \mathrm{~Bq}(2,000 \mathrm{dpm}) / 100 \mathrm{~cm}^{2}$. The contamination level was to be maintained below $3.33 \mathrm{~Bq}(200 \mathrm{dpm}) / 100 \mathrm{~cm}^{2}$ in the enclosure entry air lock area. 


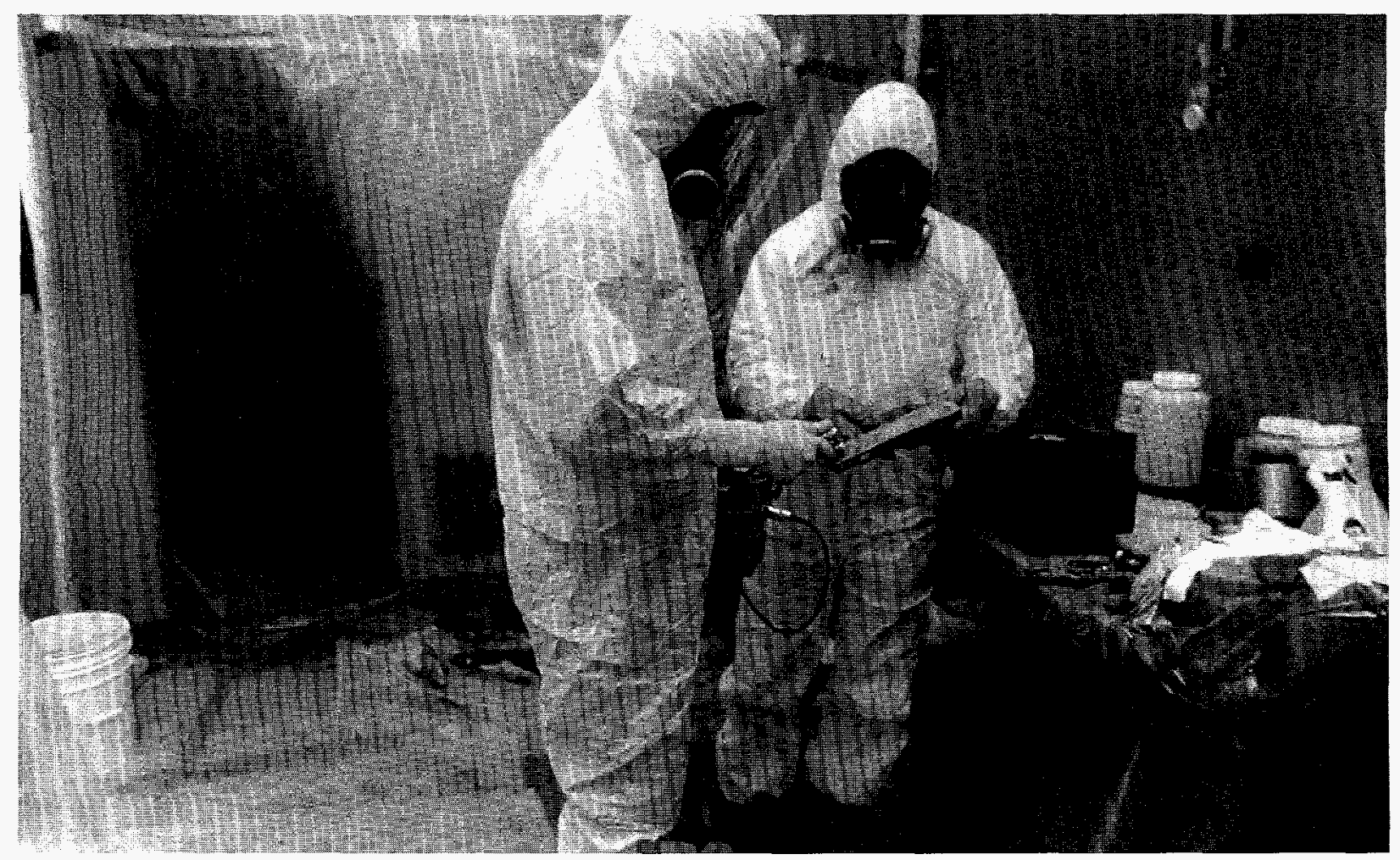

FIGURE 4.12 Disassembly and Surveying of Mechanical Vacuum Pumps from Plutonium Glovebox Systems (16379 \#10)

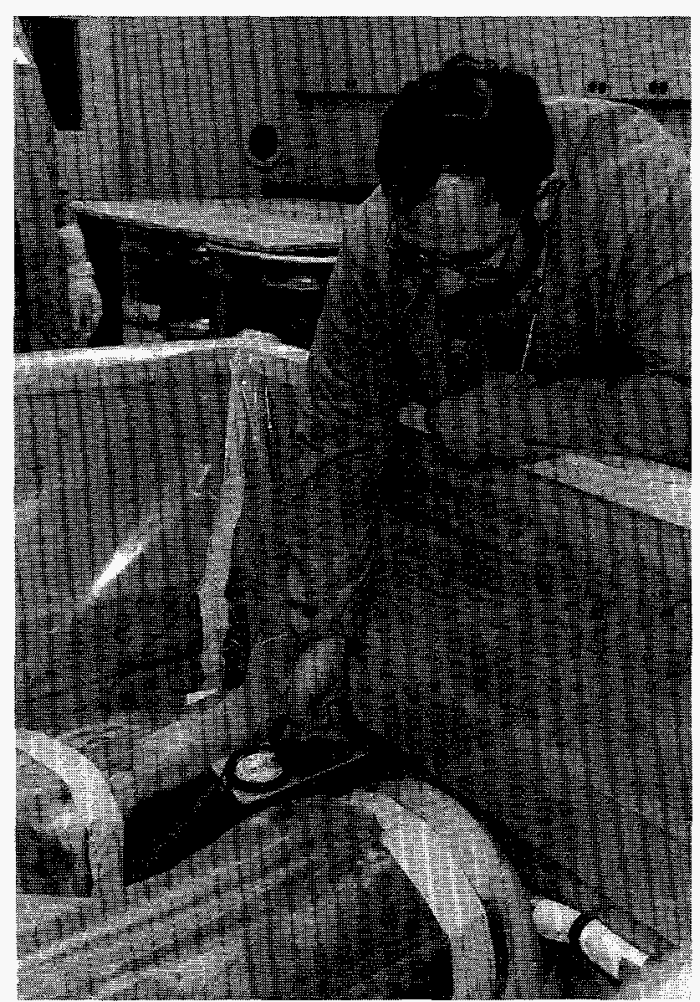

FIGURE 4.13 Surveying Bagged LowLevel Radioactive Waste Loaded into a Bin Liner (15494K \#29) 


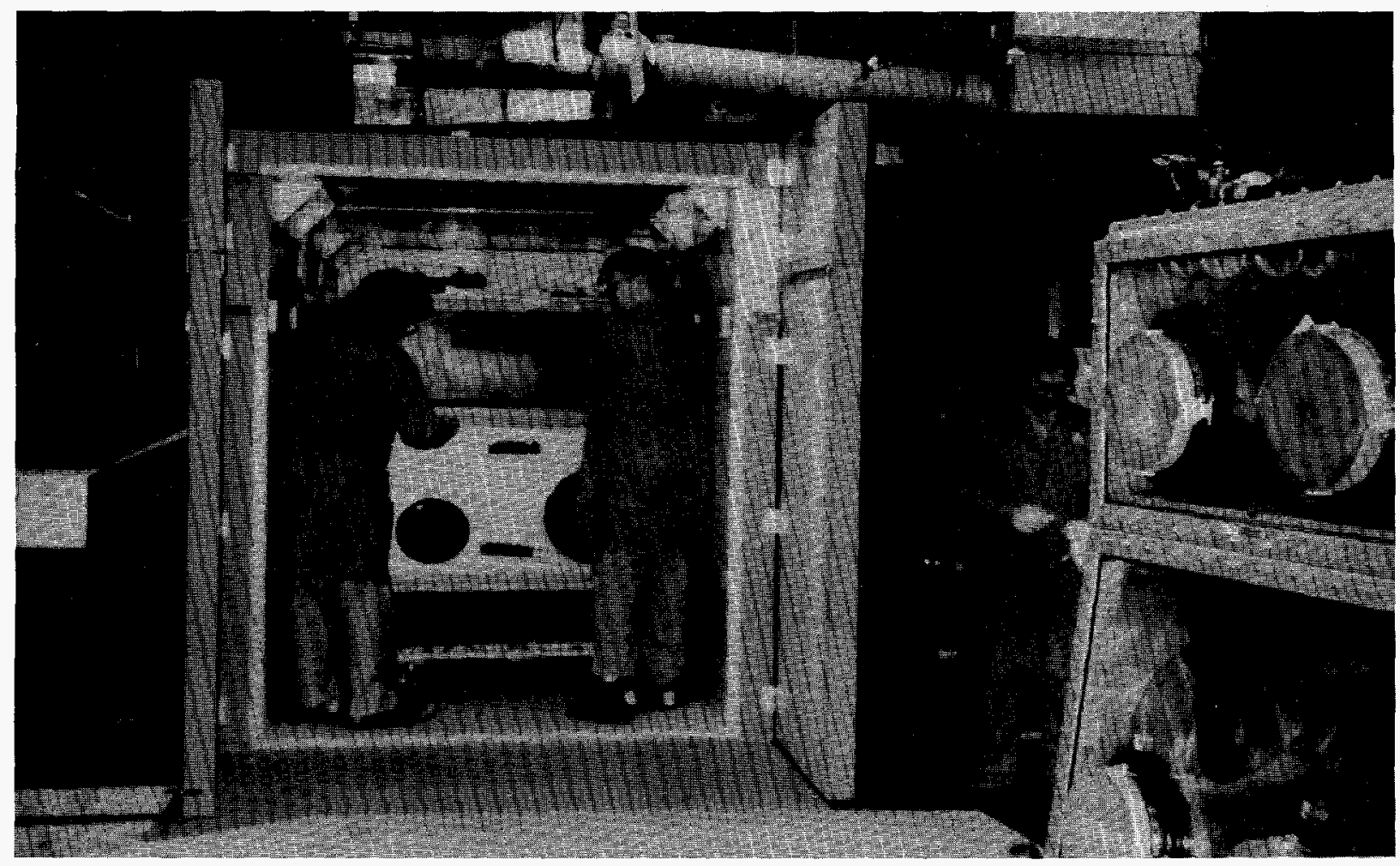

FIGURE 4.14 Pajarito Assaying of Decontaminated Gloveboxes (18778K \#1)

The phased glovebox disassembly and packaging work was planned to have budgeted collective radiation dose and Derived Air Concentration-Hour (DAC-hr) air contamination limits. Exceedance of specified limits were to be reported to the ALARA Coordinator and even higher level excessed were to be reported to the ALARA Committee. At still higher levels a Hold Point was triggered requiring an investigation. The person dose and DAC-hr levels requiring these actions are given in Table 4.2.

Work was to be safely stopped and a review of procedures and controls conducted whenever established limits were exceeded on air filter samples. Improvements in procedures and/or controls were made as required. Cumulative estimated vs measured DAC-hrs are graphed in Figure 4.15 .

The size-reduction of gloveboxes was started March 6, 1995 and completed June 2, 1995. The glovebox size-reduction enclosure is shown in Figure 4.16. Personnel entered the enclosure wearing double Tyvek protective suits and full facepiece pressurized-air-purifying respirator (PAPR). Table 4.3 lists the protective clothing and equipment worn for the gloveboxes disassembly/size-reduction work. 
TABLE 4.2 Phased Operation Glovebox Identification and Action Levels

\begin{tabular}{|c|c|c|c|c|c|c|}
\hline \multirow[b]{2}{*}{ Phase } & \multirow[b]{2}{*}{$\begin{array}{c}\begin{array}{c}\text { Number } \\
\text { of } \\
\text { Gloveboxes }\end{array} \\
\end{array}$} & \multirow[b]{2}{*}{$\begin{array}{l}\text { Budgeted } \\
\text { (person- } \\
\text { mrem) } \\
\end{array}$} & \multirow[b]{2}{*}{$\begin{array}{l}\text { Budgeted } \\
\text { (DAC-hrs) }\end{array}$} & \multicolumn{3}{|c|}{ Action Level } \\
\hline & & & & $\begin{array}{c}\text { Notify ALARA } \\
\text { Coordinator } \\
\text { (DAC Level) }\end{array}$ & $\begin{array}{c}\text { Notify ALARA } \\
\text { Committee } \\
\text { (DAC Level) }\end{array}$ & $\begin{array}{c}\text { Hold } \\
\text { Point } \\
\text { (DAC Level) } \\
\end{array}$ \\
\hline 1 & 10 & 8.0 & 3.2 & $2 x^{*}$ & $5 x^{*}$ & $40 x^{*}$ \\
\hline 2 & 29 & 78.4 & 31.4 & $2 x$ & $5 x$ & $40 x$ \\
\hline 3 & 10 & 57.0 & 22.8 & $4 x$ & $10 x$ & $40 x$ \\
\hline 4 & 12 & 171.6 & 68.6 & $6 x$ & $20 x$ & $40 x$ \\
\hline
\end{tabular}

*Action levels are shown as a multiple of the DAC level.

Note: Action levels are based on lapel filter samples, retrospective air filter samples, Alpha- 6 air monitor, or other instrumentation indications averaged over no less than a two-hour period or more than an eight-hour period.

It was determined that personnel could exit the enclosure in case the battery power to their PAPR failed, causing a decrease in respiratory protection rating from 1,000 to 100 . The decrease would be due to the change from positive pressure to negative pressure. However, a loss of positive pressure in a respirator facepiece never occurred.

Glovebox size-reduction work is shown in Figure 4.17. Figure 4.18 shows a stretch-wrap covering on a glovebox frame and a wet cheesecloth covering of a baseplate prior to saw cutting. Saber saw cutting of a glovebox frame and high volume filter sampling are depicted in Figure 4.19. Circular saw cutting of a $2.54 \mathrm{~cm}$ ( $1 \mathrm{in}$.) thick aluminum baseplate is shown in Figure 4.20 . Note in Figure 4.20 the portable cardboard disposable HEPA filtered local exhaust enclosure used for capture of radioactive dust generated by the circular saw blade. The circular saw had a carbide tipped blade with 15.75 teeth per $\mathrm{cm}$ (40 teeth per in.). Figure 4.21 shows the wrapping of a size-reduced glovebox baseplate with stretch-wrap plastic sheeting. Figure 4.22 shows wet wiping of decontamination from the size-reduction enclosure floor covering following disassembly and packaging of a glovebox. In Figure 4.23 a Health Physics technician is shown frisking a rigger employee using a scintillation type radiation detector. This was a precautionary procedure performed after moving wrapped plutonium gloveboxes. After decontamination and assaying of gloveboxes, and prior to size-reduction, it was learned that an ANL-E Reactor Engineering program had a need for three small gloveboxes. The gloveboxes scheduled for phase 1 size-reduction were evaluated and three of them were selected. They were transferred to Building 308 for the Reactor Engineering program work. 


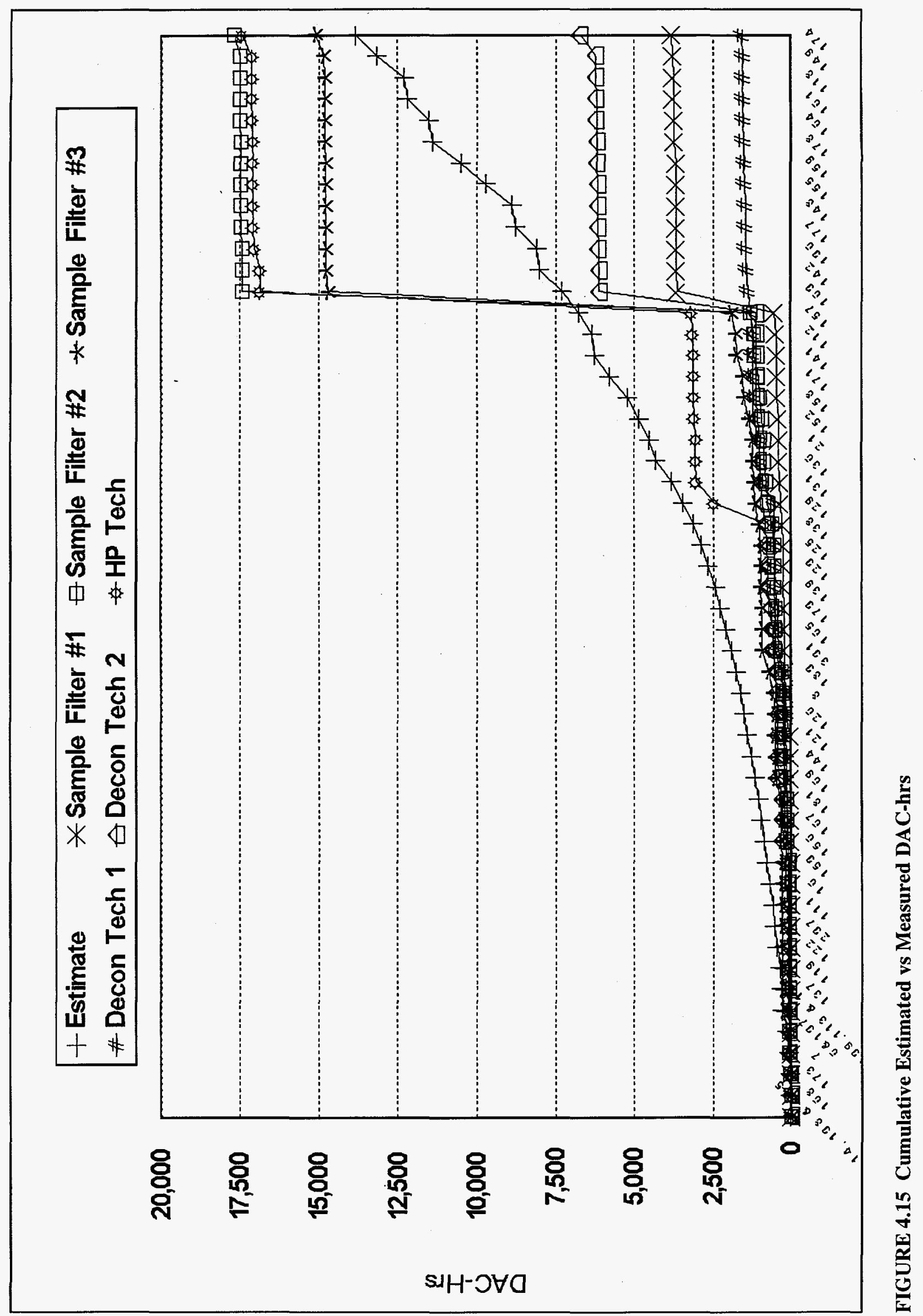




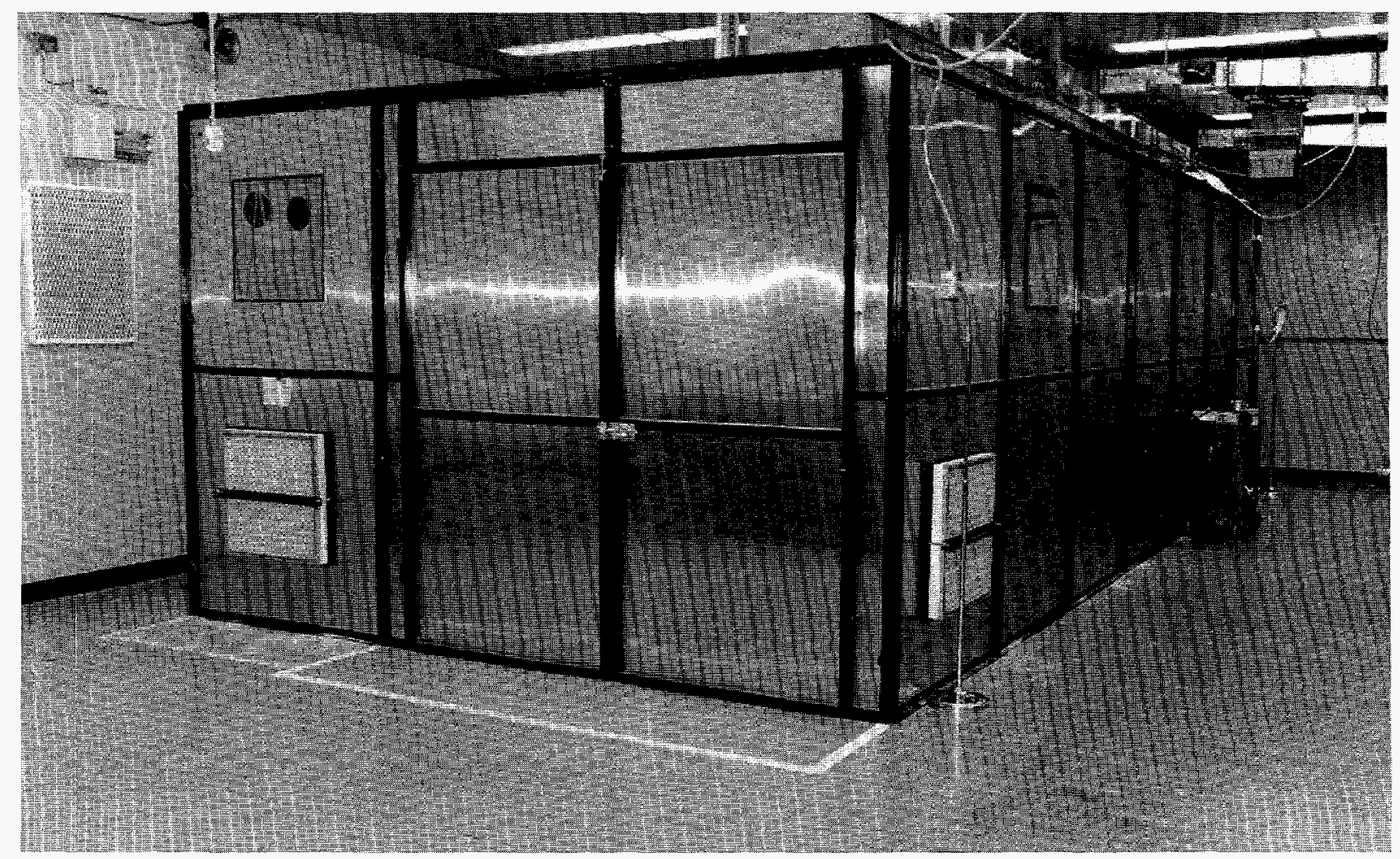

FIGURE 4.16 Gloveboxes Size-Reduction Enclosure (18877K \#4)

TABLE 4.3 Personal Protective Clothing and Equipment for Glovebox Disassembly

Undergarments were hospital-type cotton scrub suits.

(It was planned to disrobe to this point, if necessary, before an emergency shower).

Two one-piece Tyvek suits with integral booties and hood.

Full facepiece powered-air-purifying respirator (PAPR).

Two pair of latex (Surgeon's) gloves.

One pair leather outer gloves.

Pair of toe rubbers (worn over the Tyvek booties).

Note: All protective clothing seams were taped with masking tape. Communication between workers inside the enclosure and observers outside was by an intercom system using a microphone located inside near the work stations and a microphone located outside at the observation window. However, workers inside could be heard without using the microphone. 


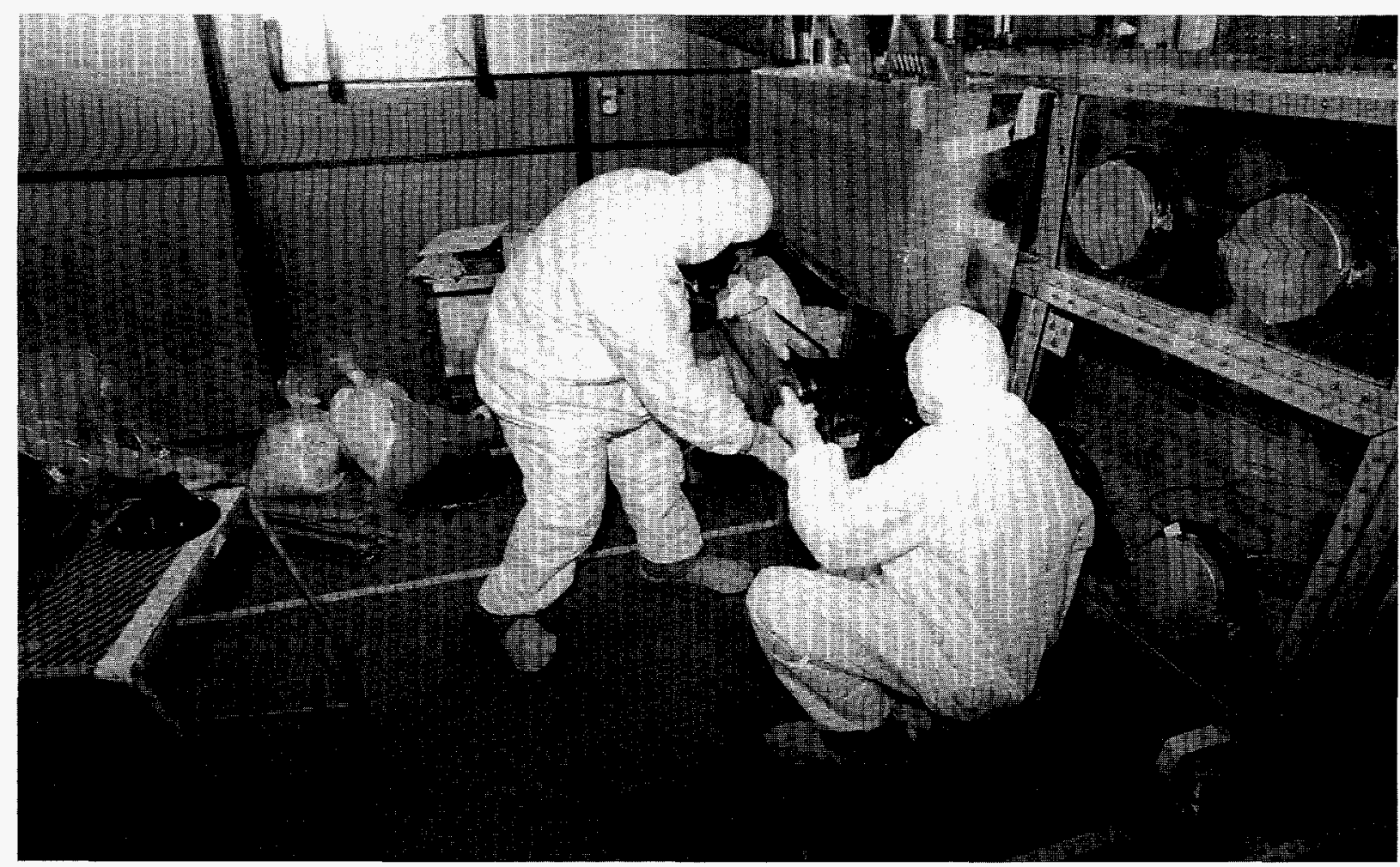

FIGURE 4.17 Size-Reduction of Plutonium Gloveboxes (19243K \#16A)

After completion of glovebox size-reduction and packaging work, the interior of the sizereduction enclosure was roller painted with strippable decontamination paint. The initial coating of decontamination paint and the final coat provided a sandwich effect for residual radioactive contamination. The two layers of decontamination paint were stripped off simultaneously and placed low-level radioactive waste drums. The size-reduction enclosure filters were removed and packaged for assay, and all interior surfaces were surveyed and decontaminated. The enclosure was disassembled August 7 to 28, 1995. It was then resurveyed and, as a precaution, all surfaces were wiped with a wetted rag. It was finally found to be acceptable for general future use by ANL-E Waste Management.

After disassembly and removal of the size-reduction enclosure, the contractor removed the glovebox utilities, including copper tubing supply-and-exhaust ventilation piping. All material was surveyed and packaged as low-level radioactive waste. This work ran from June 5, 1995 to August 4, 1995. The contractor demobilized and left the ANL-E site August 9, 1995.

ANL-E Environmental Waste Management personnel removed $722 \mathrm{~m}^{2}\left(7,764 \mathrm{ft}^{2}\right)$ of vinylasbestos floor tile and floor tile mastic from project radiological control areas, including nine laboratories and associated work corridors. This work was started August 21, 1995 and was completed January 12, 1996. 


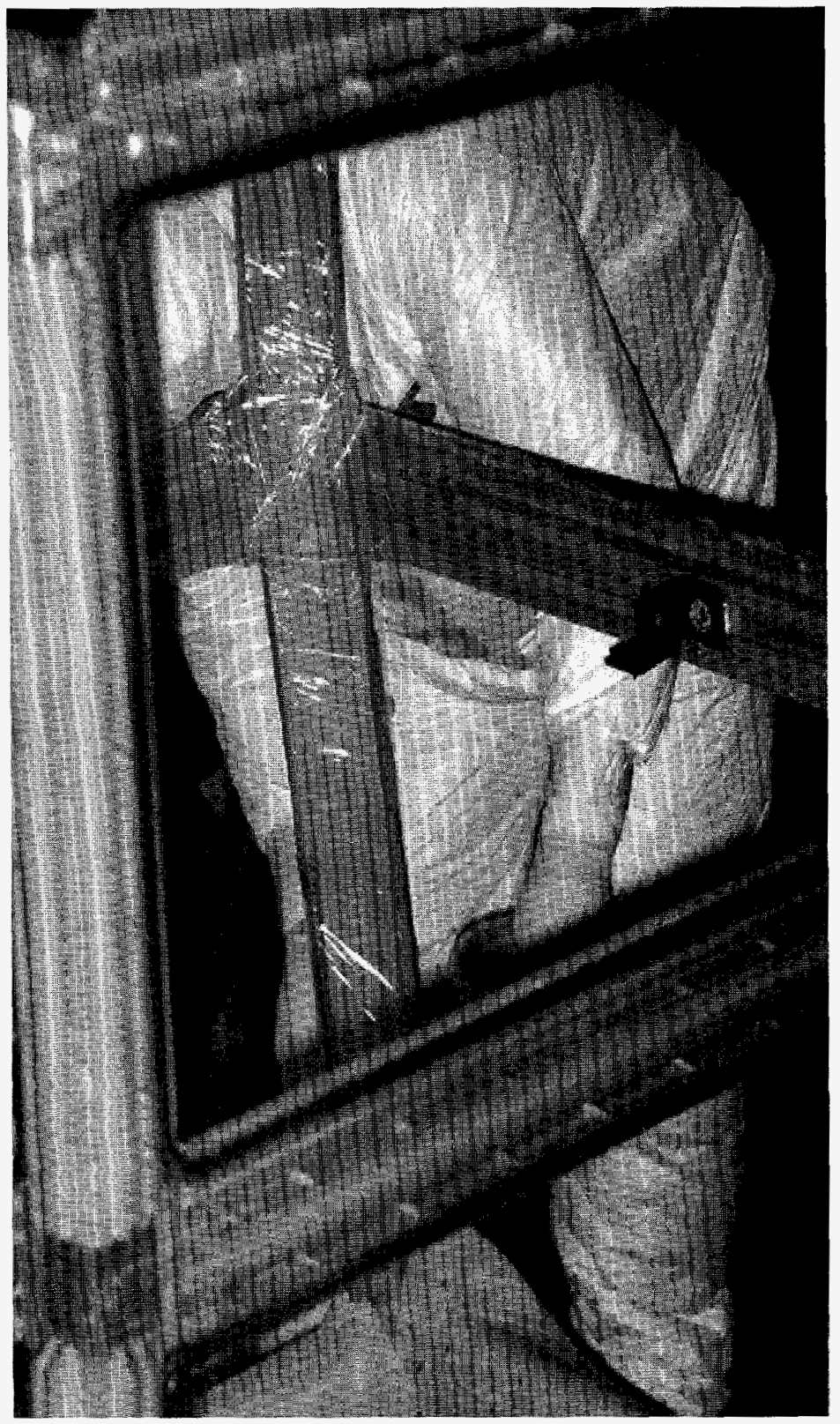

FIGURE 4.18 Stretch-Wrap on Glovebox Frame and Wet Cheesecloth Covering of the Baseplate Prior to SizeReduction 


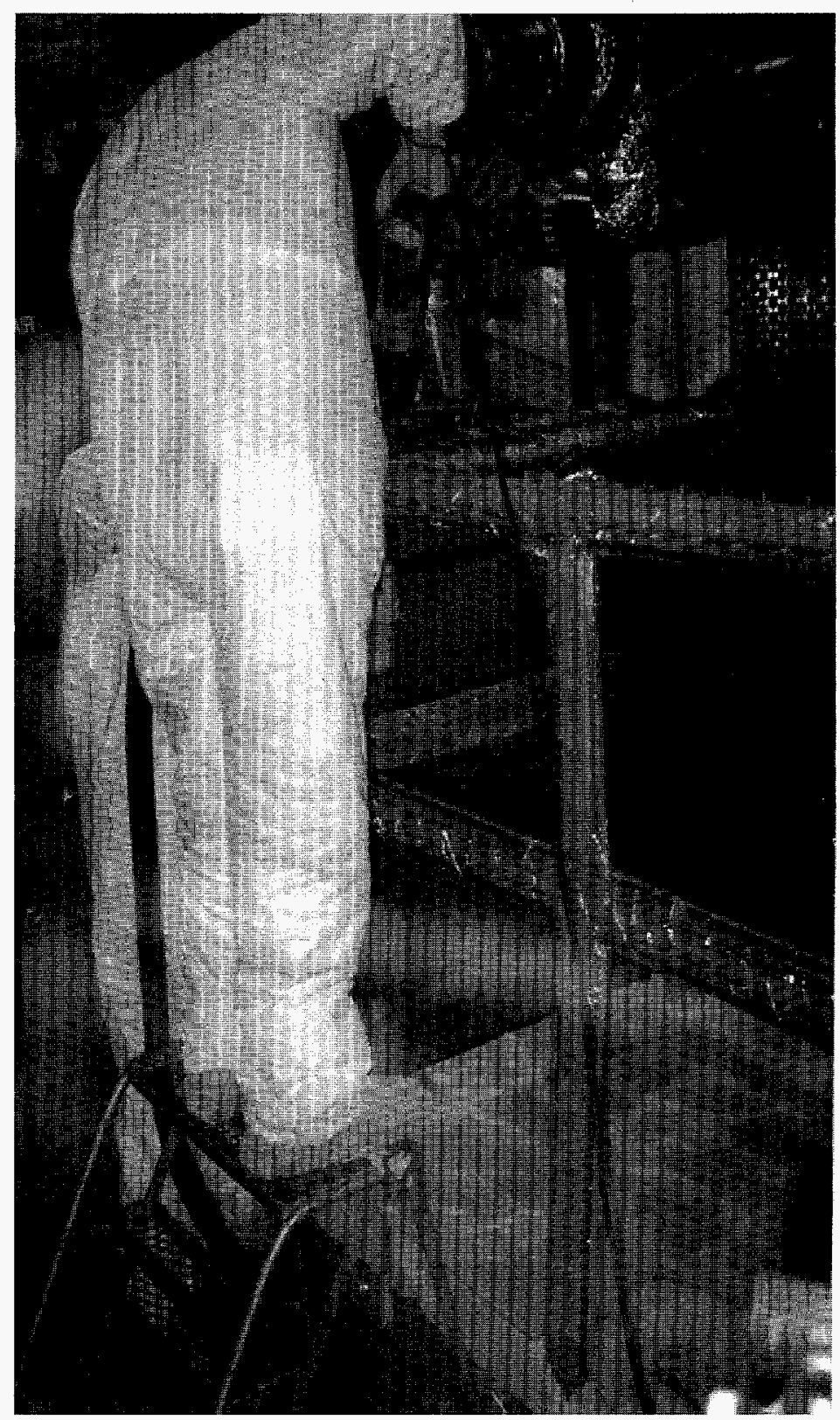

FIGURE 4.19 Saber Saw Cutting of a Stretch-Wrapped Glovebox Frame and High Volume Air Filter Sampling 


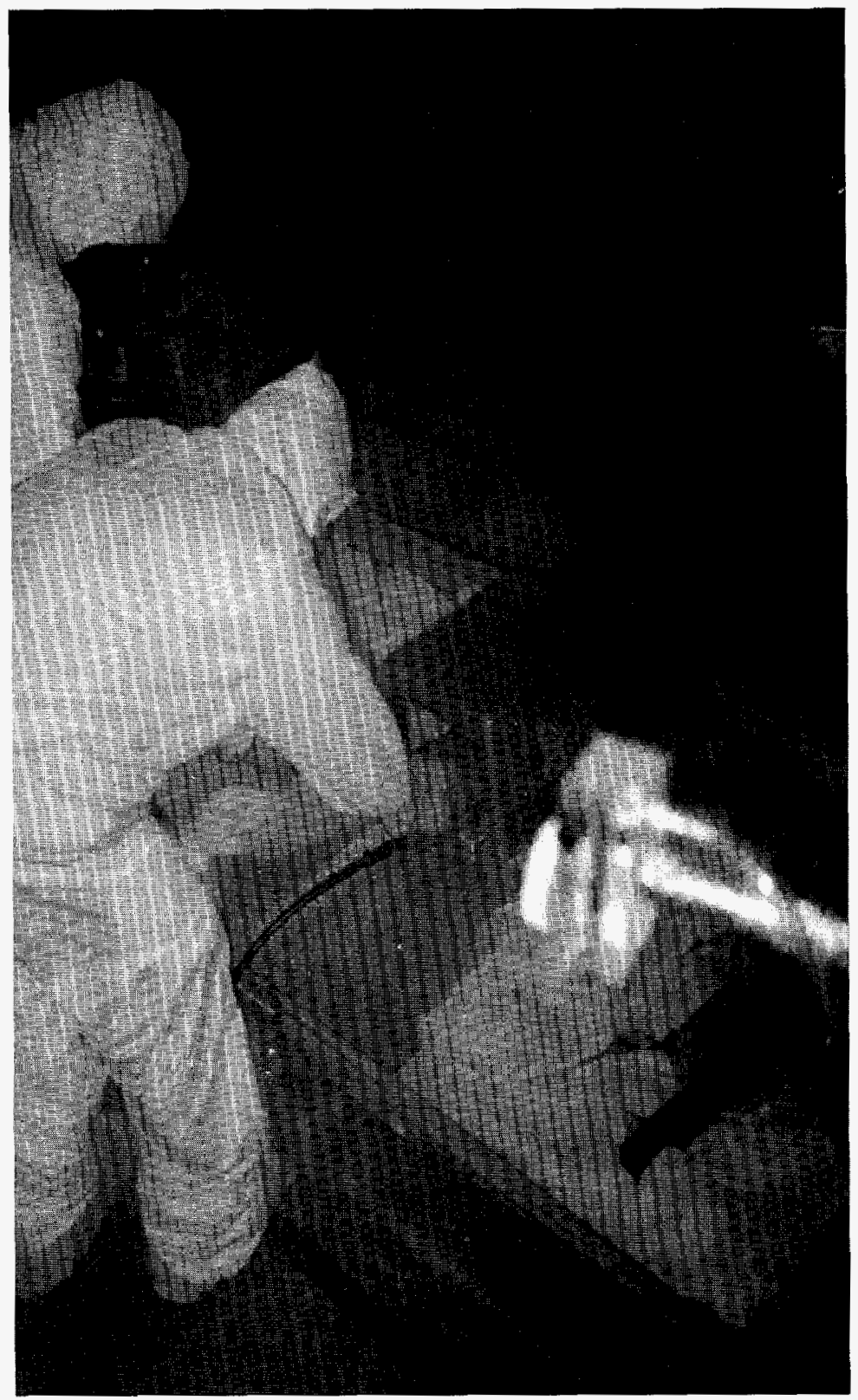

FIGURE 4.20 Circular Saw Cutting of a Glovebox Baseplate Using a Portable HEPA Filtered Local Exhaust Enclosure 


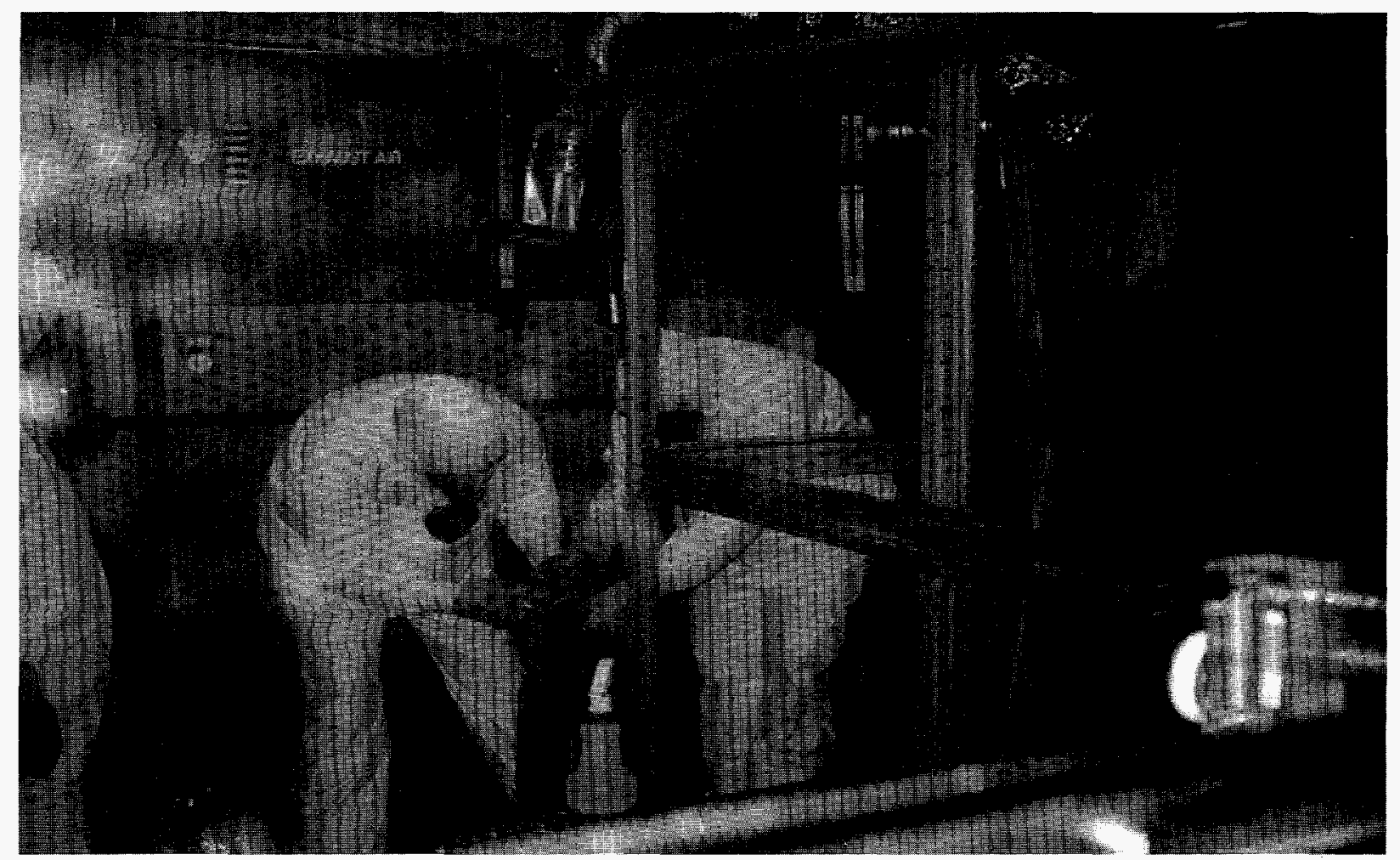

FIGURE 4.21 Wrapping Size-Reduced Glovebox Baseplate with a Stretch-Wrap

Surveillance and Maintenance actions included:

- Daily Health Physics surveys in work areas.

- Daily Health Physics surveys in the central corridor of the radiation control area.

- Daily monitoring of used magenta lab coats and toe rubbers.

- Daily source check at hand-and-shoe monitors.

- Daily change-out of the filters in the Alpha-6 air monitors. These monitors had audible and flashing light alarm signals.

- Weekly Health Physics surveys in radiation control areas where work was not being conducted. 


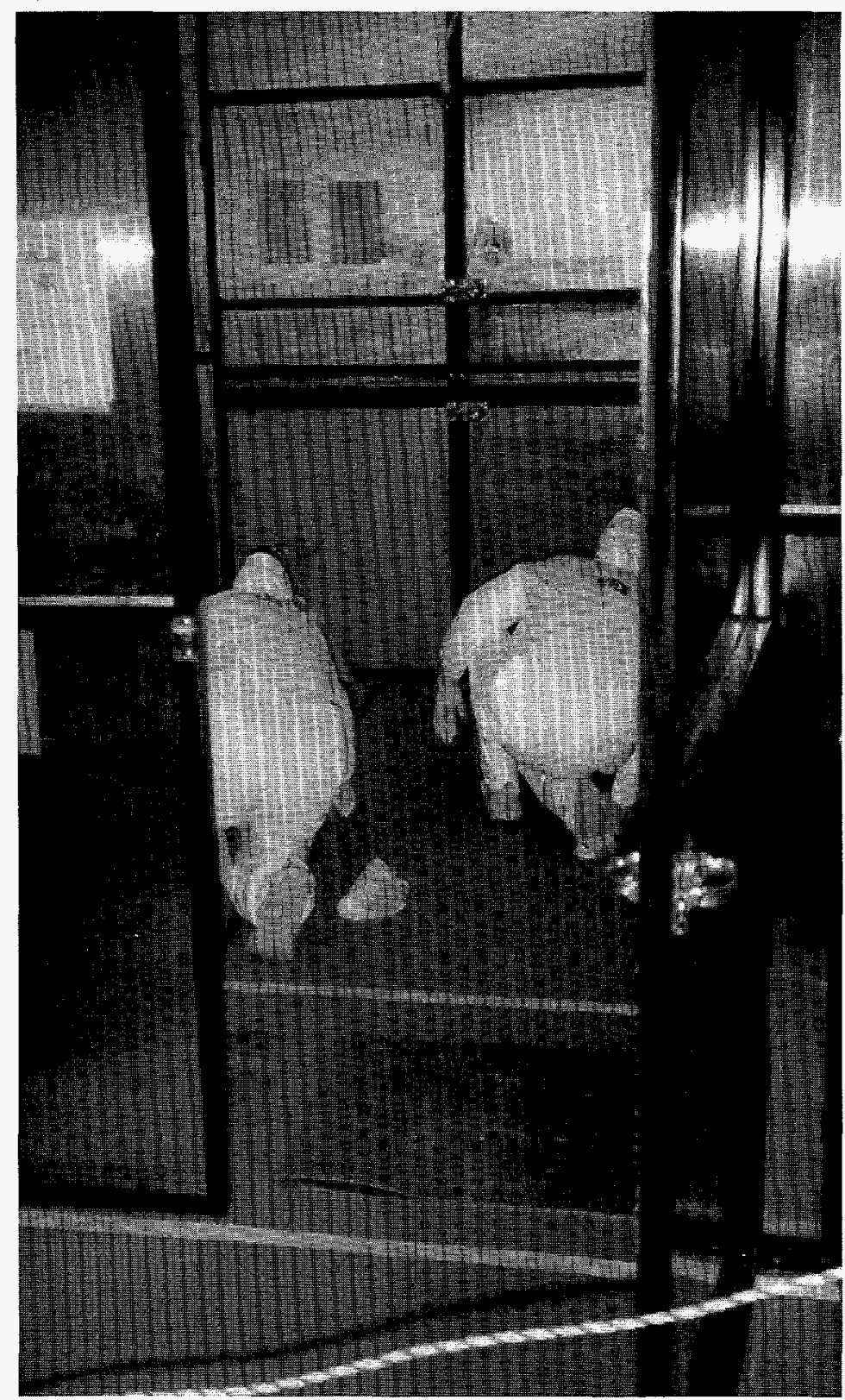

FIGURE 4.22 Wet Wiping for Decontamination of a SizeReduction Enclosure Floor Covering Following Disassembly and Packaging of a Glovebox 


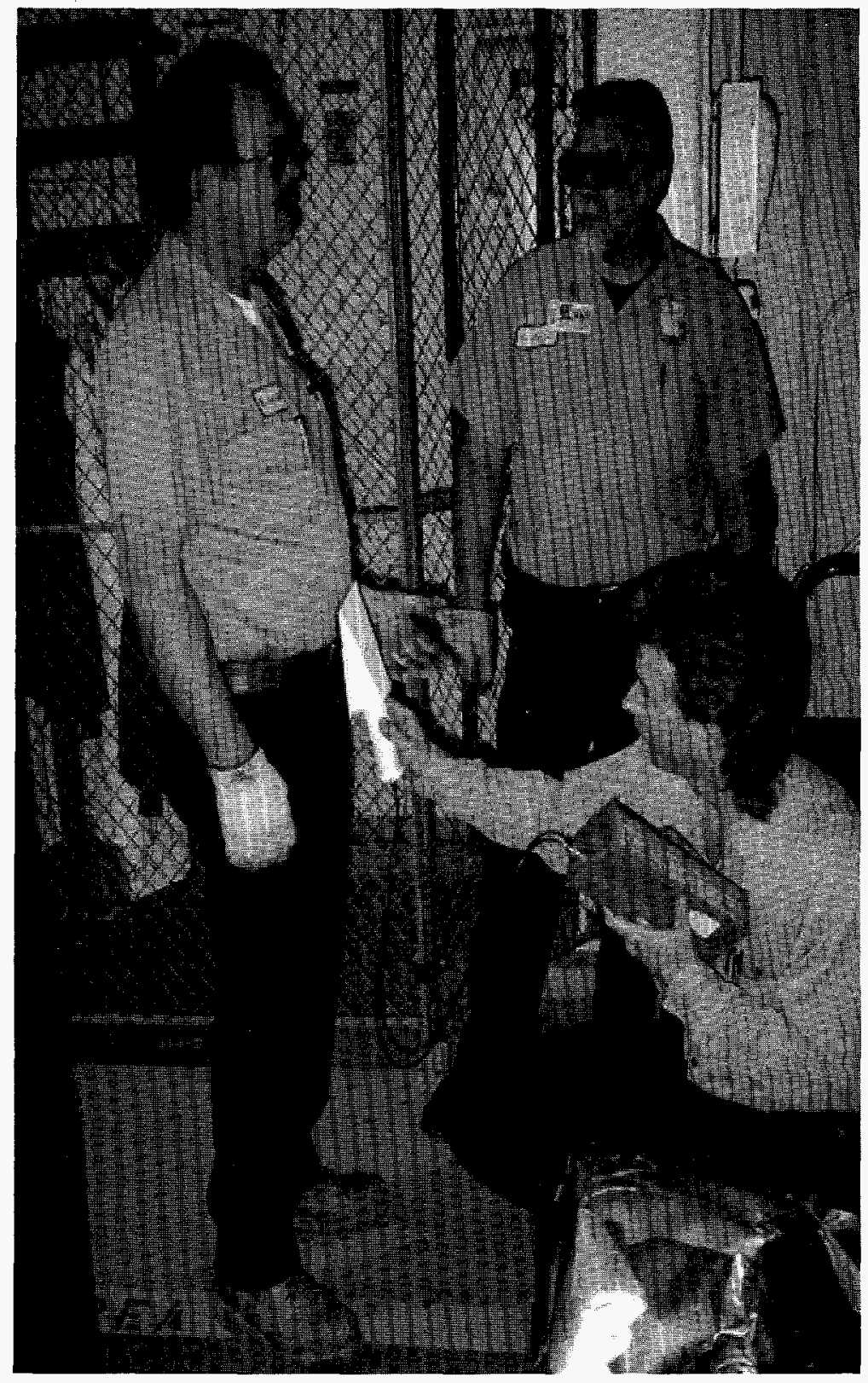

FIGURE 4.23 Health Physics Technician Frisking a Rigger Employee 
- Weekly Health Physics surveys in selected areas outside the radiation control area.

- Weekly change-out of the gloveboxes exhaust stack sampling filters.

- Weekly review of the contractor's log.

\subsection{WASTE DISPOSAL}

Low-Level waste disposal was by shipment of bins and drums to the DOE-Hanford Site in accord with their radioactive waste acceptance criteria. Low-level radioactive waste was shipped in steel bins secured by chains on flatbed trucks. There were 43 half bins, 1 full size bin, and 10 drums shipped in Super Tiger type B containers because they exceeded type A quantities. Transuranic and mixed waste was placed into ANL-E interim storage pending availability of a DOE disposal site. There was a protracted time period for development and reviews of procedures for unloading the type B shipping containers at the radioactive waste disposal site. After revision of procedures, authorization for type B waste shipments was obtained. The loaded truck shipment of low level radioactive waste, category $\mathrm{B}$, is shown in Figure 4.24.

\subsection{POST-DECOMMISSIONING RADIOLOGICAL SURVEY}

The post decommissioning radiological survey of the nine laboratories and interior corridors was conducted by ANL-E Health Physics personnel. A total of about $735 \mathrm{~m}^{2}\left(7,900 \mathrm{ft}^{2}\right)$ of surface area was surveyed directly and by smear sampling. After spot areas found to be contaminated were effectively decontaminated, the nine laboratories and the interior corridors met the DOE unrestricted release criteria per DOE Order 5400.5, as detailed in Table 4.4.

The plan objectives of decontaminating to non-detectable or background radioactivity levels was the desired final condition. The conditions in the fan loft were surveyed and documented but the fan loft area was not intended for free-release because there were other connected radioactive exhaust systems located in this area.

The laboratory and corridor surfaces were marked with a one square meter grid system. Each grid was uniquely identified with an alpha-numeric coordinate. Figure 4.25 shows Health Physics technicians marking a vertical grid line on a laboratory wall. A self-controlled motorized scissors lift platform was utilized for surveying, smear sampling, and paint removal sampling of upper wall surfaces and ceilings. Figure 4.26 shows a Health Physics Technician surveying a wall grid. The survey scanning technique was designed to provide a three-second probe residence time over all surface points surveyed. Where radioactive contamination was detected, the grid was marked 


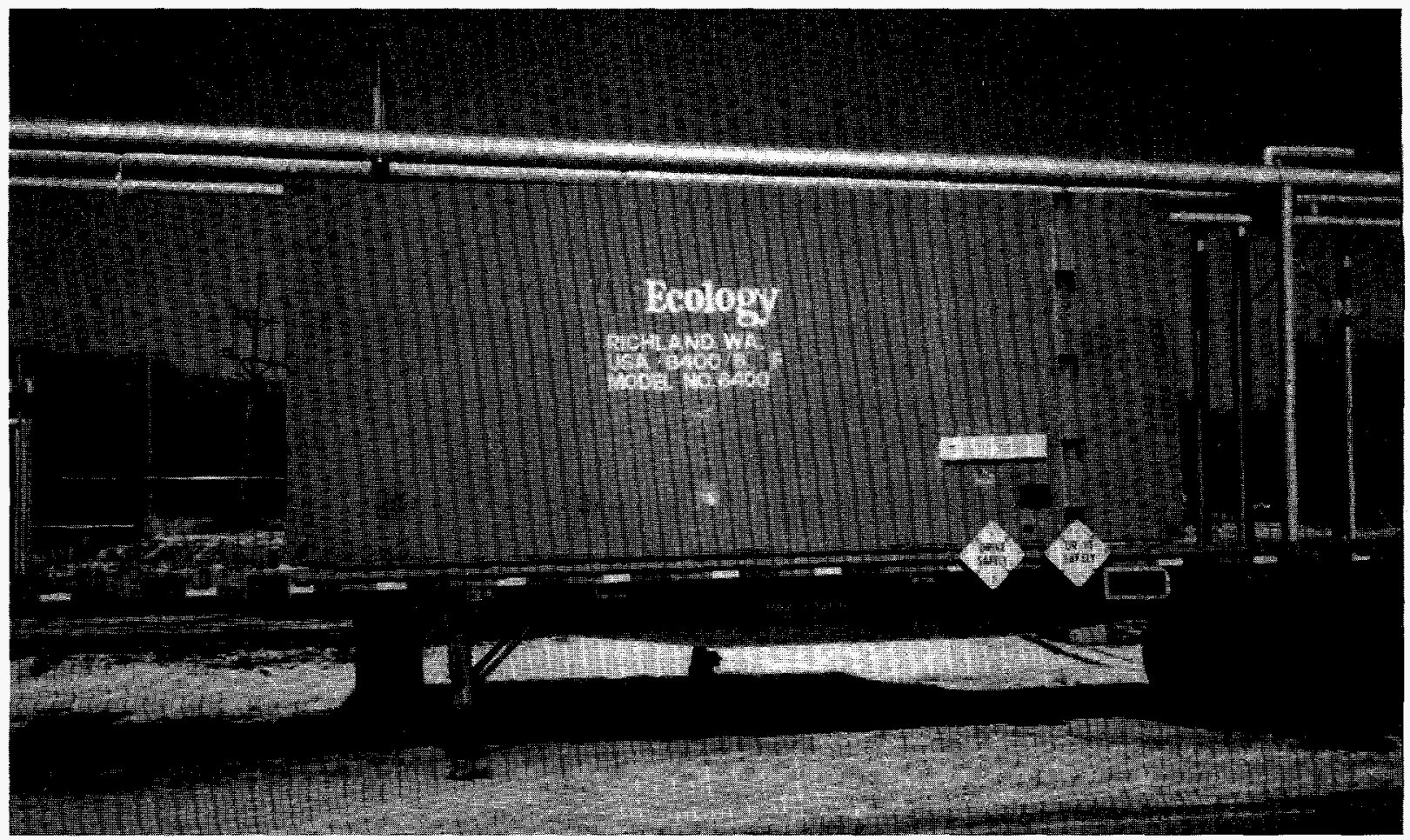

FIGURE 4.24 Loaded Super Tiger Truck Shipment of Type B Radioactive Waste

TABLE 4.4 DOE Unrestricted Release Criteria (DOE Order 5400.5)

$<0.33 \mathrm{~Bq}$ (20 dpm) alpha/ $100 \mathrm{~cm}^{2}$ removable.

$<1.67 \mathrm{~Bq}(100 \mathrm{dpm})$ alpha/ $100 \mathrm{~cm}^{2}$ average over $1 \mathrm{~m}^{2}$ fixed and removable.

$<5 \mathrm{~Bq}(300 \mathrm{dpm})$ alpha/ $100 \mathrm{~cm}^{2}$ fixed and removable maximum.

$<167 \mathrm{~Bq}(1,000 \mathrm{dpm})$ beta-gamma/ $100 \mathrm{~cm}^{2}$ removable.

$<83.3 \mathrm{~Bq}(5,000 \mathrm{dpm})$ beta-gamma/ $100 \mathrm{~cm}^{2}$ average over $1 \mathrm{~m}^{2}$ fixed and removable.

$<250 \mathrm{~Bq}(15,000 \mathrm{dpm})$ beta-gamma/ $100 \mathrm{~cm}^{2}$ fixed and removable maximum.

Note: The release criteria were taken from DOE Order 5400.5, Radiation Protection of the Public and the Environment, Change 2, dated 1/7/93, and summarized in a memo to distribution from Raymond F Pelletier, DOE, "Application of DOE 5400.5 requirements for release and control of property containing residual radioactive material", dated 11/17/95. 


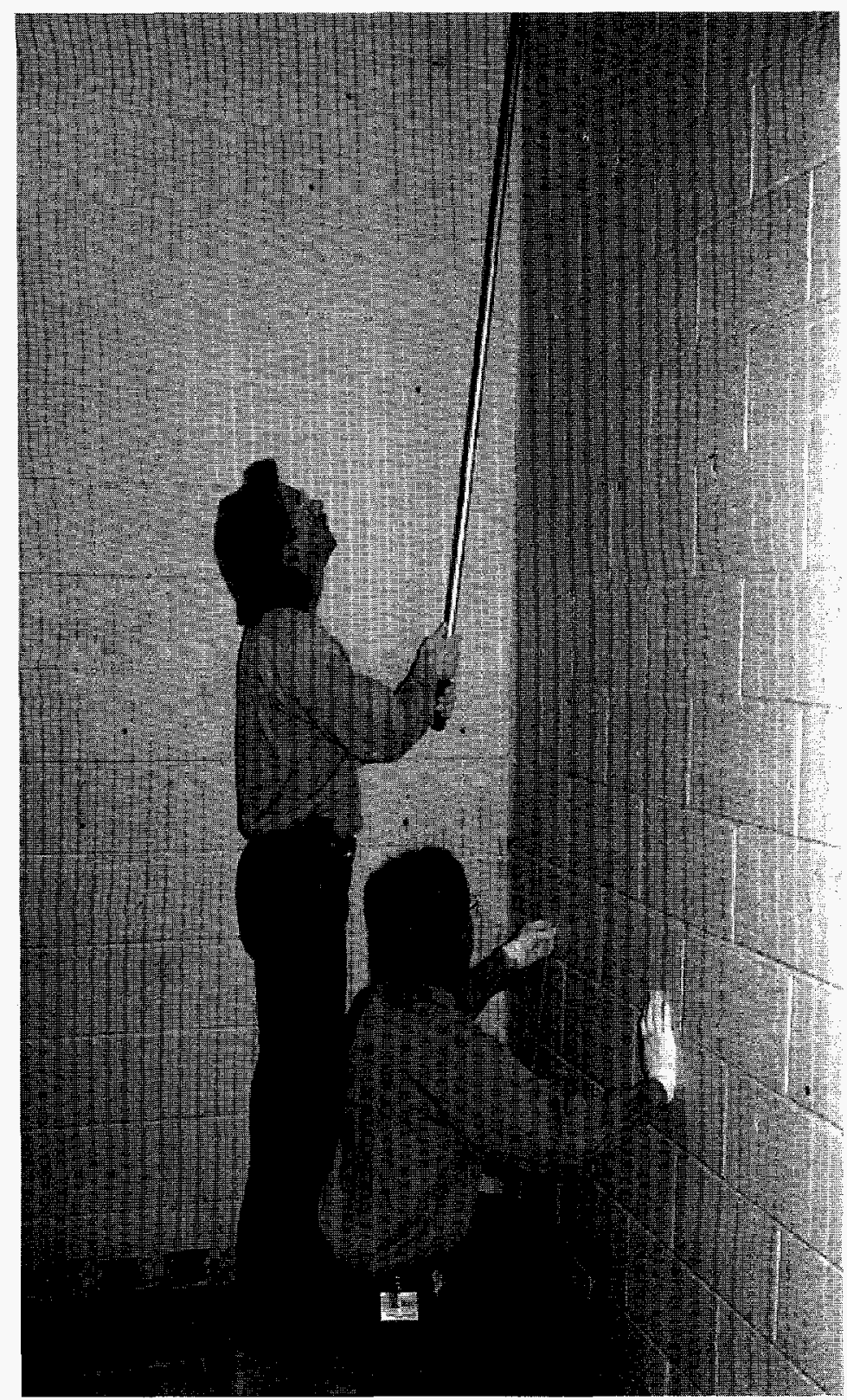

FIGURE 4.25 Health Physics Technicians Marking $1 \mathbf{m}^{2}$ Grids on Laboratory Wall, Ceiling, and Floor Surfaces (20759K \#9A) 


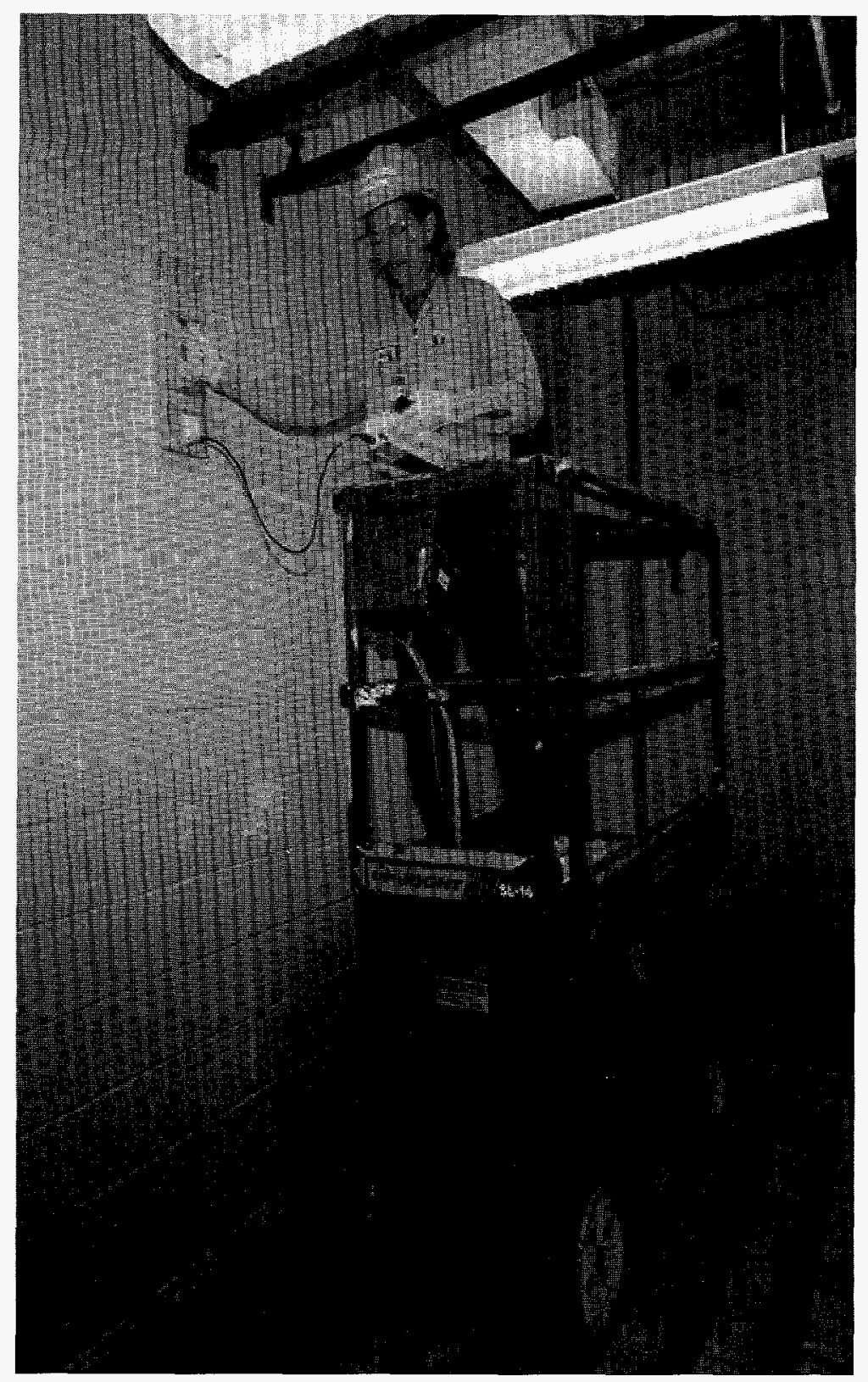

FIGURE 4.26 Health Physics Technician Surveying a Wall Surface from a Motorized Scissors-Lift Platform Using a $435 \mathrm{~cm}^{2}$ Probe Gas-Proportional Counter 
and resurveyed with a $100 \mathrm{~cm}^{2}$ probe to further define contamination. Static measurements of 60 -second duration were made to assess the amount of contamination. A Health Physics technician is shown in Figure 4.27 surveying an electrical power strip after it was deenergized and the cover was removed. Figure 4.28 shows a Health Physics technician surveying a laboratory floor.

In addition to direct surveys of surfaces, smear samples and paint removal samples were taken. Figure 4.29 depicts a Health Physics technician taking a dry smear sample of a laboratory wall location. A $47 \mathrm{~mm}$ (1.73 in.) diameter glass fiber filter was used for one-pass smear sampling of a $100 \mathrm{~cm}^{2}$ area at each sampling location. Paint was removed from selected sample areas on laboratory walls and ceilings using an electric drill and special fitting created for this project. An electric drill with $2.54 \mathrm{~cm}$ ( 1 in.) diameter medium wire cone brush was adapted for paint removal. A $6.35 \mathrm{~cm}$ ( 2.5 in.) diameter PVC tee fitting with a $47 \mathrm{~mm}$ (1.73 in.) diameter glass fiber filter attached to the tee and a $28 \mathrm{lpm}(1 \mathrm{cfm})$ vane-type vacuum pump provided collection of the removed paint. A hole was cut in the top of the PVC tee to provide access for the drill chuck key and this was covered with tape during use. A Health Physics technician is shown in Figure 4.30 commencing removal of paint from a $100 \mathrm{~cm}^{2}$ wall sample location using the electric drill and special fitting. Following removal of paint the exposed concrete block wall surface was then directly surveyed with a $100 \mathrm{~cm}^{2}$ scintillation meter probe. Both the dry smear samples and the paint samples were counted using an automated gas-flow proportional counting system.

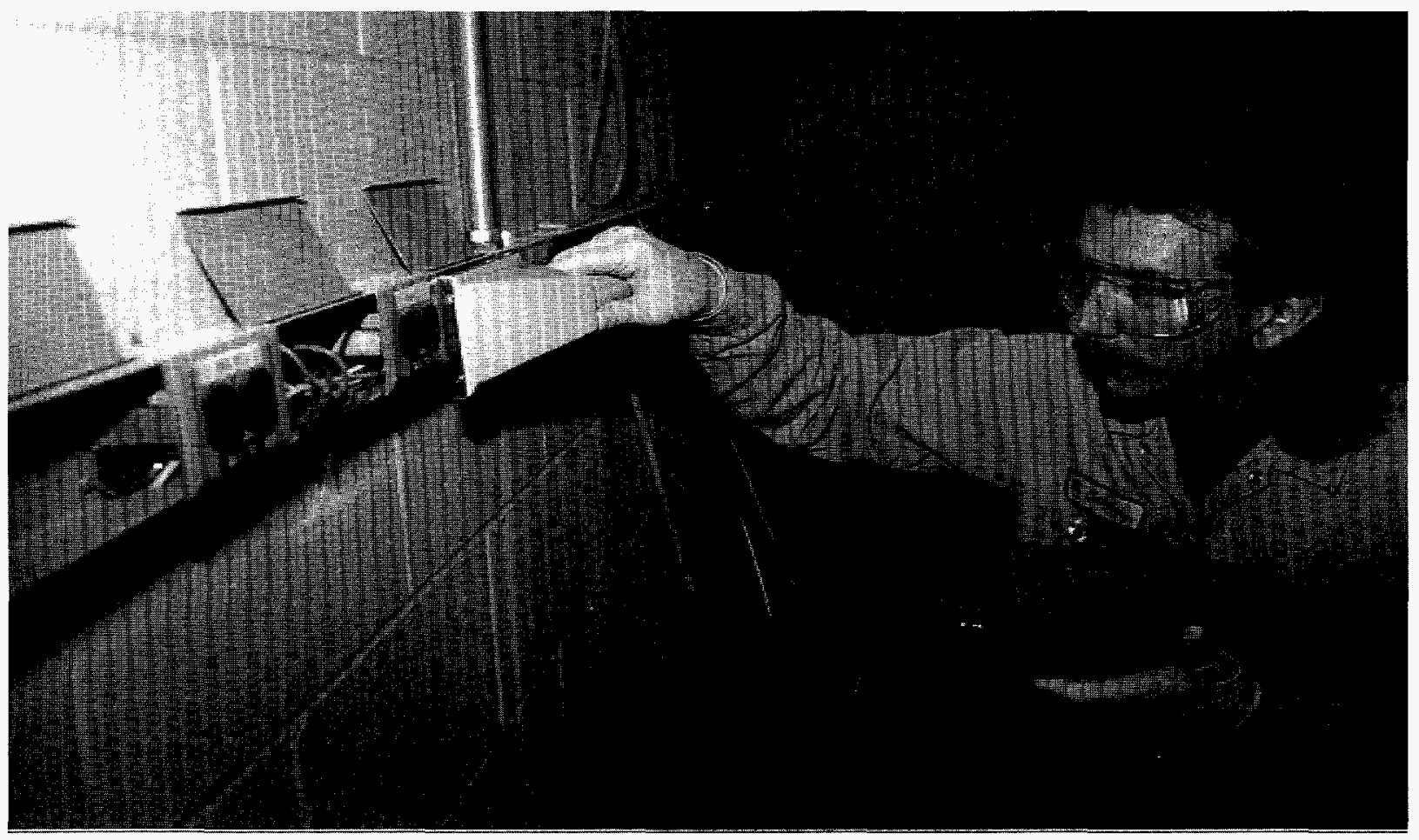

FIGURE 4.27 Health Physics Technician Surveying an Electrical Strip Using a $100 \mathrm{~cm}^{2}$ Probe Scintillation-Type Instrument (20759K \#18A) 


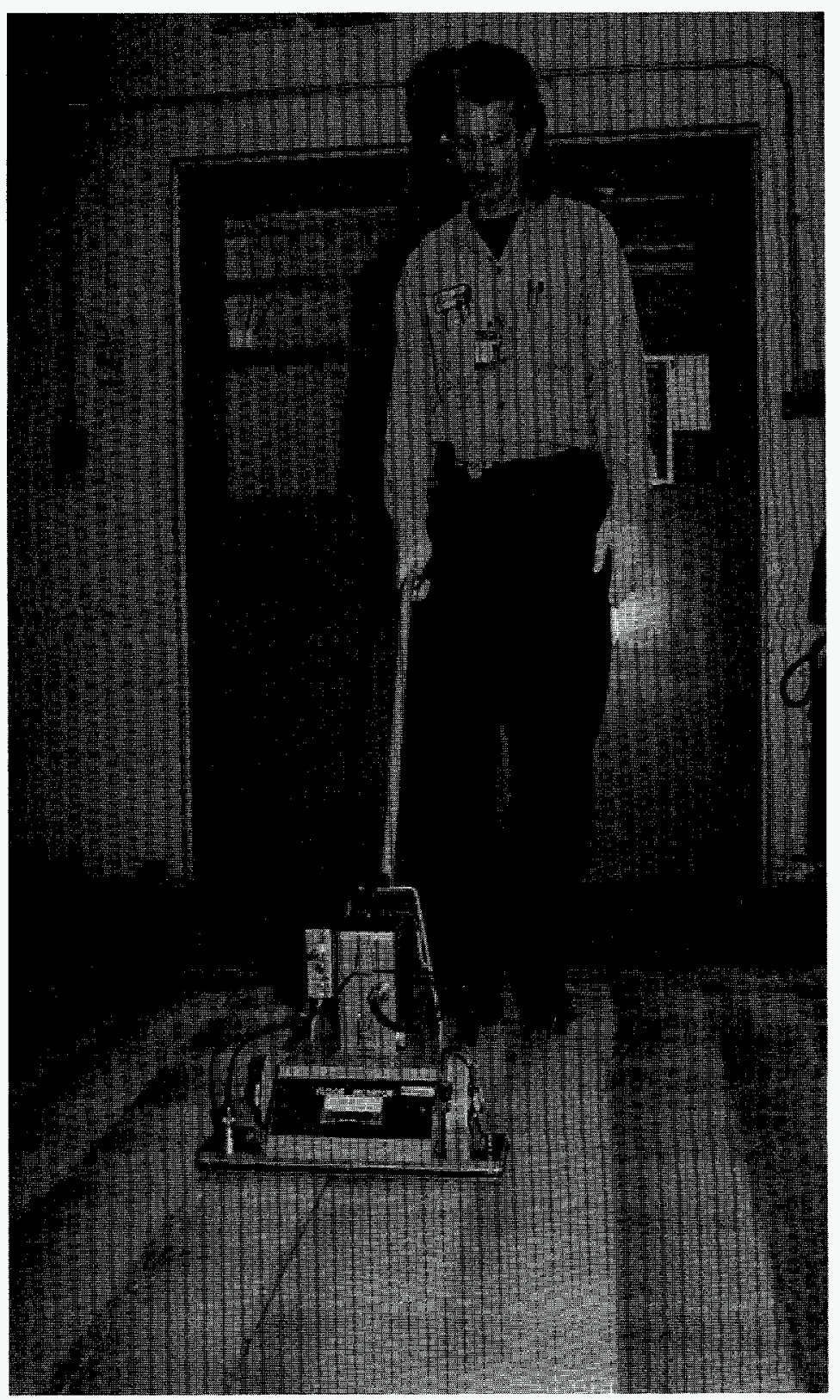

FIGURE 4.28 Health Physics Technician Surveying a Laboratory Floor with a $330 \mathrm{~cm}^{2}$ Probe Gas-Proportional Counter (20759K \#25A) 


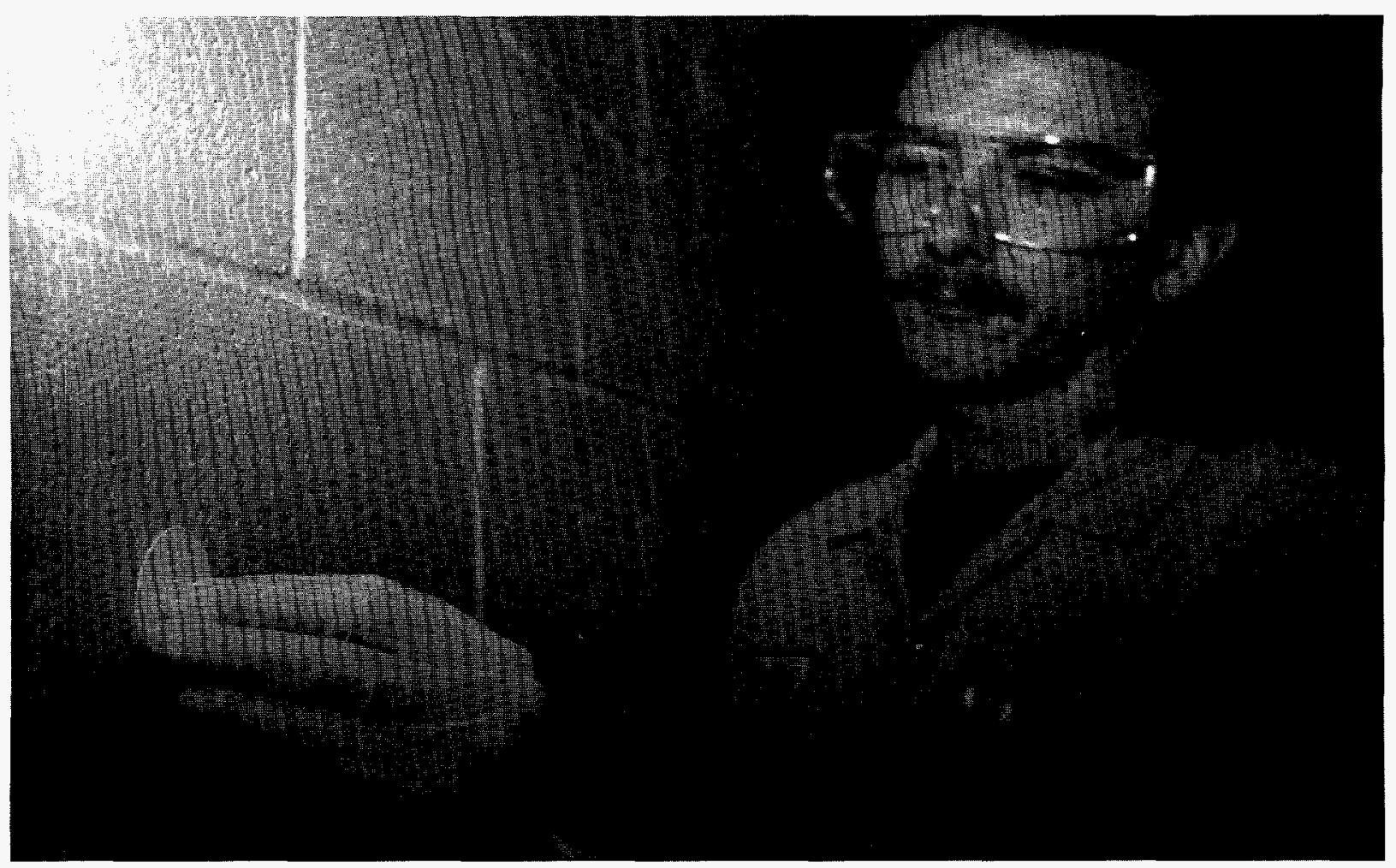

FIGURE 4.29 Health Physics Technician Taking a Dry Smear Sample of a $100 \mathrm{~cm}^{2}$ Wall Area (20759K \#29A)

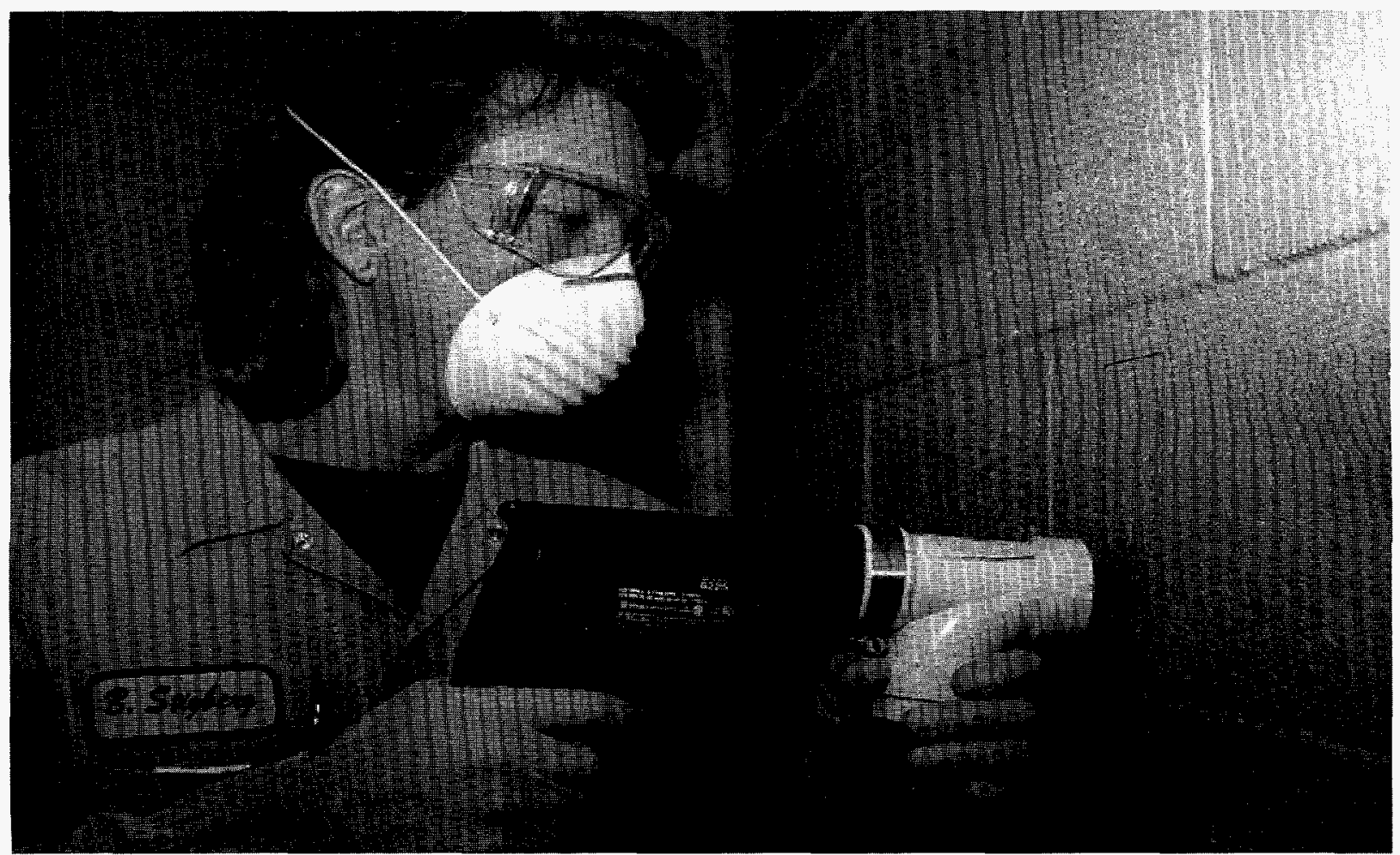

FIGURE 4.30 Health Physics Technician Collecting a Paint Sample Using a Power-Operated Wire Cone Brush with Exhaust Filter Attachment (20759K \#33A) 
Following the completion of the ANL-E Health Physics Summary report of the post D\&D final radiological survey, there was an independent verification survey (Reference 17) for the DOE conducted by the Oak Ridge Institute for Science and Education (ORISE). The final report for the verification survey described the project scope, methods, and findings. The report summary, stated that "All final verification surface activity levels and exposure rates were within the DOE guidelines for release to unrestricted use."

\subsection{POST-DECOMMISSIONING HAZARDOUS CHEMICAL CONDITION}

The hazardous materials involved in this project were lead, depleted uranium, mercury, acids, caustics, and asbestos. The lead was packaged as TRU mixed waste. The uranium was packaged as radioactive waste. The acids and caustics were neutralized, solidified, and packaged as TRU waste. The mercury was solidified and packaged as TRU mixed waste. Vinyl-asbestos floor tiles and mastic were packaged as radioactive mixed waste. No hazardous materials remained in the project areas at the completion of the project. 


\section{COSTS AND SCHEDULES}

The project was completed February 29,1996 at a cost of $\$ 6.9$ million. The total cost and estimated breakdown of costs by functional activities are shown in Table 5.1

TABLE 5.1 Project Costs

\begin{tabular}{lc}
\hline \multicolumn{1}{c}{ Activity } & $\begin{array}{c}\text { Cost } \\
\text { (in thousands) }\end{array}$ \\
\hline Project total & $\$ 6,900$ \\
Project Management/Support & 1,177 \\
Surveillance and Maintenance & 975 \\
Plans/Procedures & 455 \\
Remove and Package Gloveboxes Contents & 1,396 \\
Decontaminate and Assay Gloveboxes & 500 \\
Disassemble and Package Gloveboxes & 895 \\
Decontaminate Facilities & 526 \\
Waste Disposal & 926 \\
Project Closeout & 77 \\
\hline
\end{tabular}




\section{WASTE GENERATED}

The amounts of radioactive wastes generated by this project is shown in Table 6.1.

Weight of radioactive waste:

TRU:

$8,874 \mathrm{~kg}$ ( 9.8 tons)

LLW:

$45,316 \mathrm{~kg}$ (50.0 tons)

Total:

$54,190 \mathrm{~kg}$ (59.8 tons)

The estimated vs actual amount of radioactive waste generated is depicted in Figure 6.1. Radionuclides in the radioactive waste stream is shown in Table 6.2 and their distribution is shown in Figure 6.2.

TABLE 6.1 Radioactive Waste Generated

\begin{tabular}{lrl}
\hline \multicolumn{1}{c}{ Radioactive Waste Types } & Waste Amount Generated \\
\hline TRU waste: & $27.9 \mathrm{~m}^{3}$ & $(997.5 \mathrm{cf})$ \\
133 drums (55 gal or 7.5 cf each) & & \\
Low-level waste (LLW): & & \\
49 steel bins (67 cf each) & $91.9 \mathrm{~m}^{3}$ & $(3,283 \mathrm{cf})$ \\
3 steel bins (135 cf each) & $11.3 \mathrm{~m}^{3}$ & $(405 \mathrm{cf})$ \\
20 drums & & \\
(55 gal or 7.5 cf each) & $4.2 \mathrm{~m}^{3}$ & $(150 \mathrm{cf})$ \\
4 round fiber (4 cf each) & $0.45 \mathrm{~m}^{3}$ & $(16 \mathrm{cf} *)$ \\
21 round fiber (1 cf each) & $0.59 \mathrm{~m}^{3}$ & $(21 \mathrm{cf} *)$ \\
71 TV cartons (4 cf each) & $7.95 \mathrm{~m}^{3}$ & $(284 \mathrm{cf} *)$ \\
Subtotal LLW & $116.5 \mathrm{~m}^{3}$ & $(4,159 \mathrm{cf})$ \\
Total radioactive waste & $144.4 \mathrm{~m}^{3}$ & $(5,156.5 \mathrm{cf})$ \\
\hline
\end{tabular}

* Round fiber and TV cartons were subsequently used as fill for low-level waste bins or compacted to $25 \%$ of original volume prior to disposal. 
TABLE 6.2 Radionuclides in Waste Stream

\begin{tabular}{lcrr}
\hline TRU: & Pu-238 & $5.2 \mathrm{GBq}$ & $(1.4 \mathrm{Ci})$ \\
& Pu-239 & $44.4 \mathrm{GBq}$ & $(12.0 \mathrm{Ci})$ \\
Pu-240 & $81.4 \mathrm{GBq}$ & $(22.0 \mathrm{Ci})$ \\
Pu-241 & $74.0 \mathrm{GBq}$ & $(20.0 \mathrm{Ci})$ \\
Am-241 & $12.6 \mathrm{Gbq}$ & $(3.4 \mathrm{Ci})$ \\
Other & $4.4 \mathrm{GBq}$ & $(1.2 \mathrm{Ci})$ \\
Subtotal TRU & $222.0 \mathrm{GBq}$ & $(60.0 \mathrm{Ci})$ \\
LLW: & Pu-239 & $0.7 \mathrm{GBq}$ & $(0.2 \mathrm{Ci})$ \\
& $1.9 \mathrm{GBq}$ & $(0.5 \mathrm{Ci})$ \\
& Pu-240 & $2.9 \mathrm{GBq}$ & $(0.8 \mathrm{Ci})$ \\
& $1.5 \mathrm{GBq}$ & $(0.4 \mathrm{Ci})$ \\
Other & $7.0 \mathrm{GBq}$ & $(1.9 \mathrm{Ci})$ \\
Subtotal LLW & $229.0 \mathrm{GBq}$ & $(61.9 \mathrm{Ci})$ \\
\hline
\end{tabular}


Baseline Estimate

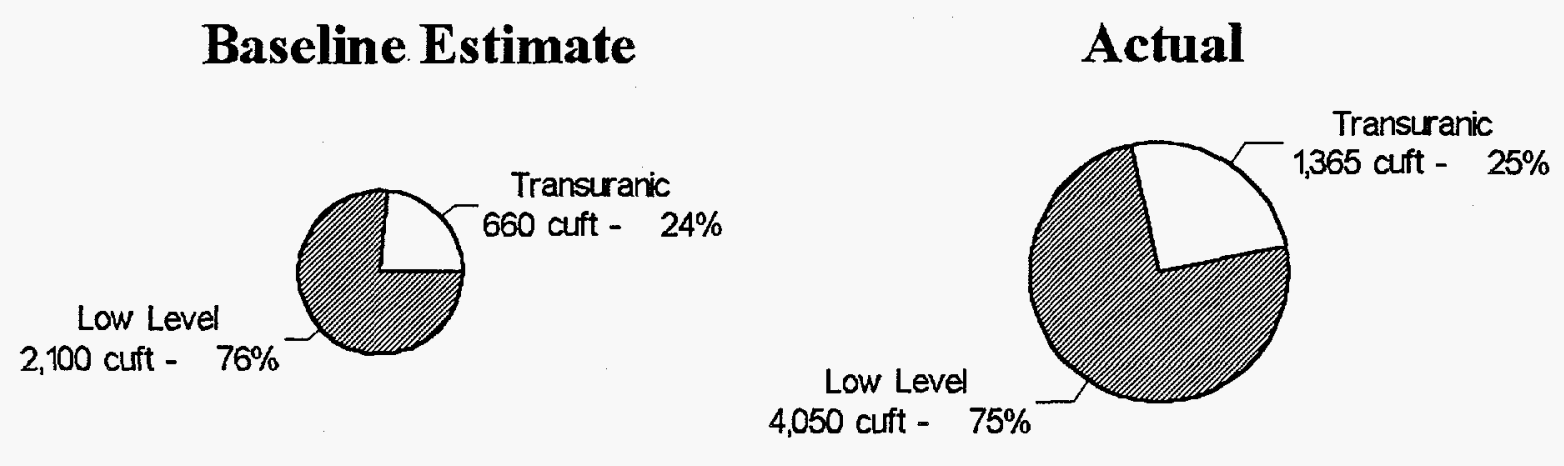

Actual

4,050 cuft - $75 \%$

FIGURE 6.1 Estimated vs Actual Amount of Radioactive Waste Generated

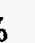

\section{(1)}

Put240

$2.2 \mathrm{E}+01-35.4 \%$
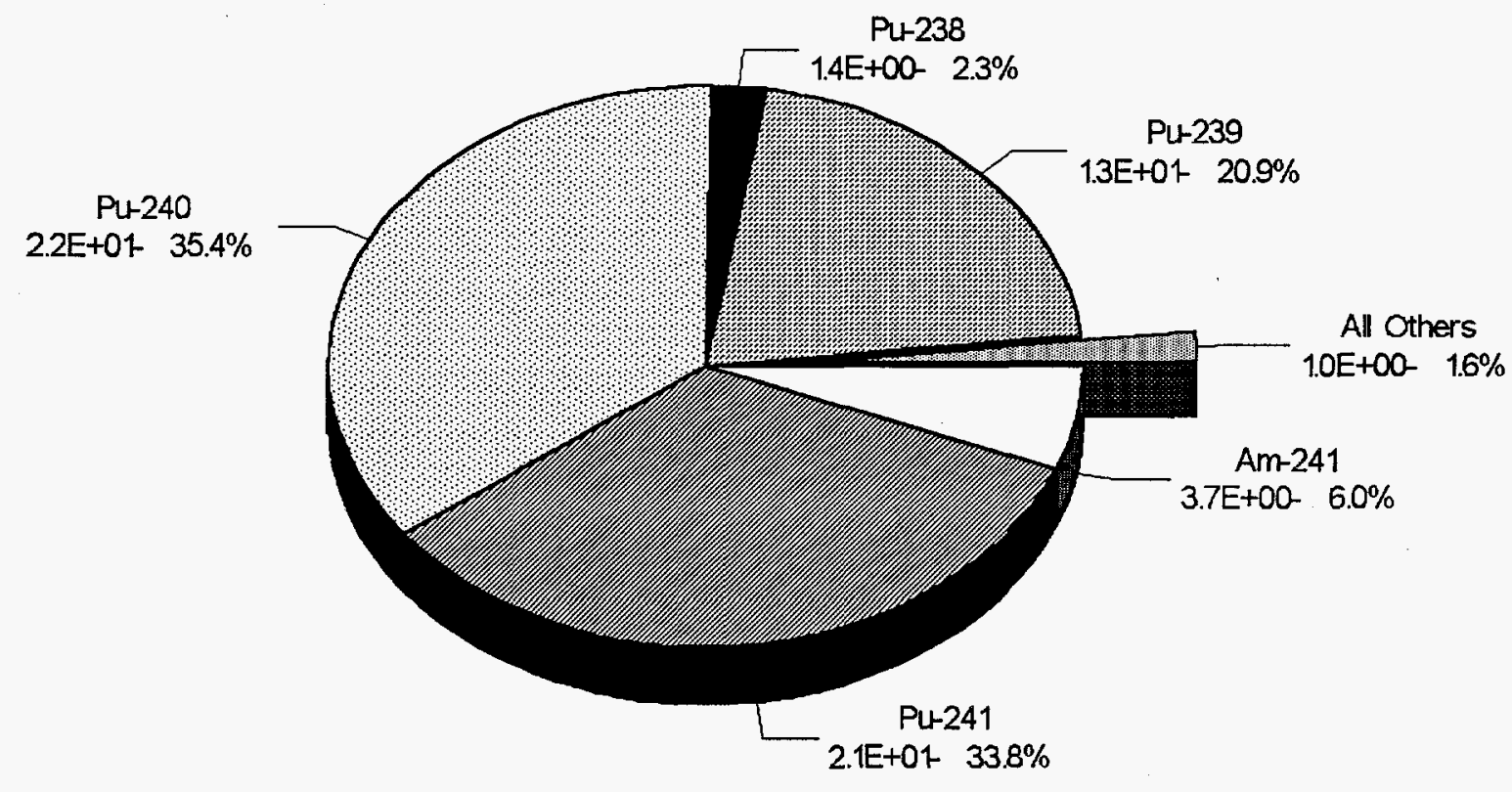

FIGURE 6.2 Radionuclides Distribution 


\section{OCCUPATIONAL EXPOSURE TO PERSONNEL}

All exposures associated with the proposed action were forecasted to be within applicable guidelines and regulatory limits. The collective effective dose for this project was forecasted to be 43 person-mSv (4.3 person-rem) in the Action Description Memorandum (Reference 3).

The actual collective effective doses received, as determined by personal dosimetry, bioassay, and whole body counting for the project, are given in Table 7.1

The collective dose to project workers was $29.3 \%$ of the forecasted dose in the project Action Description Memorandum. Attention to ALARA principles was effective in minimizing radiation doses to personnel. The internal and external collective dose components, of the collective Total Effective Dose Equivalent (TEDE), were as follows:

Collective internal effective dose $=37.3 \%$ of collective TEDE equivalent $(50$ year committed)

Collective external effective dose $=62.7 \%$ of collective TEDE (penetrating, whole body)

A comparison of budgeted, estimated, and actual internal exposure received during glovebox size reduction and packaging work is shown in Figure 7.1. Note that the actual internal exposures, as measured by bioassay, were less than the budgeted doses. They were also less than the estimated doses which were based on air sampling results and an assigned respiratory protection factor. 
TABLE 7.1 Radiation Doses Received by Workers

Collective effective dose equivalent (internal plus external) Collective effective dose equivalent (internal only, 50 year commitment)

Collective effective dose (external only, whole body penetrating)

Collective equivalent dose (bone surfaces)

Collective extremity dose (hand)

Maximum individual effective dose equivalent (external plus internal)

Maximum individual effective dose (penetrating, whole body external)

Maximum individual effective dose equivalent (internal only, 50 year commitment)

Maximum individual single occurrence effective dose equivalent (external plus internal)
12.6 person-mSv (1.26 person-rem)

4.7 person-mSv ( 0.47 person-rem)

7.9 person-mSv (0.79 person-rem)

67.8 person-mSv (6.78 person-rem)

26.8 person-mSv (2.68 person-rem)

1.55 person-mSv (0.155 person-rem)

1.05 person-mSv (0.105 person-rem)

0.9 person-mSv (0.09 person-rem)

0.9 person-mSv (0.09 person-rem) 


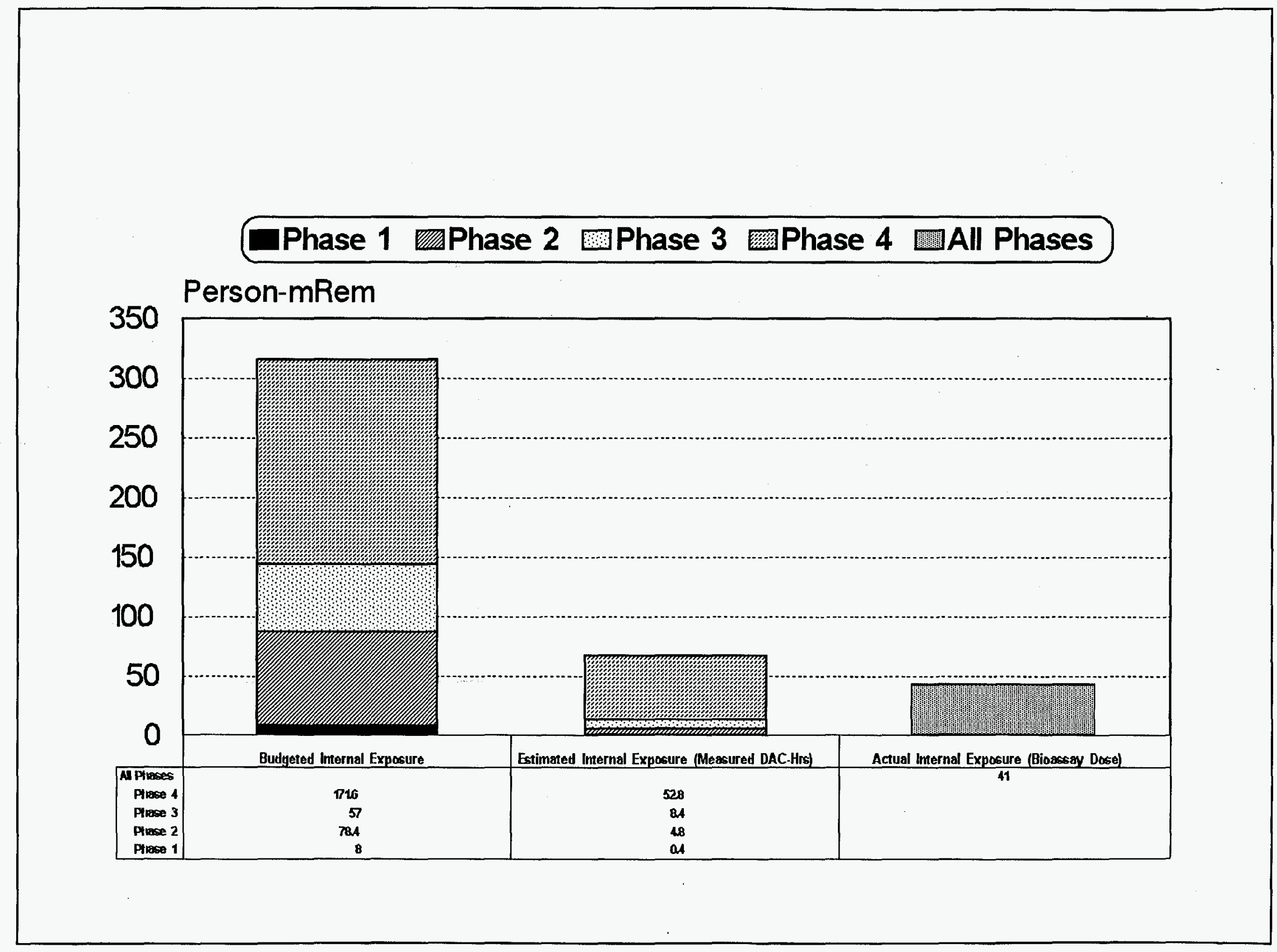




\section{FINAL FACILITY STATUS}

The final radiological survey was carried out by ANL-E Health Physics personnel. The final survey report, dated 7 March 1996, concluded that the project laboratories, corridors, and offices met the DOE unrestricted use criteria. The laboratories were left with false ceiling tile, floor tile, and all glovebox systems removed. The Independent Verification Survey conducted for the DOE also concluded that DOE unrestricted release criteria were met.

The final status of laboratories DL-216 and DL-222 are shown in Figures 8.1 and 8.2 respectively. The final status of interior corridor 26B is shown in Figure 8.3. These conditions were representative of the final status of the laboratories and interior corridors.

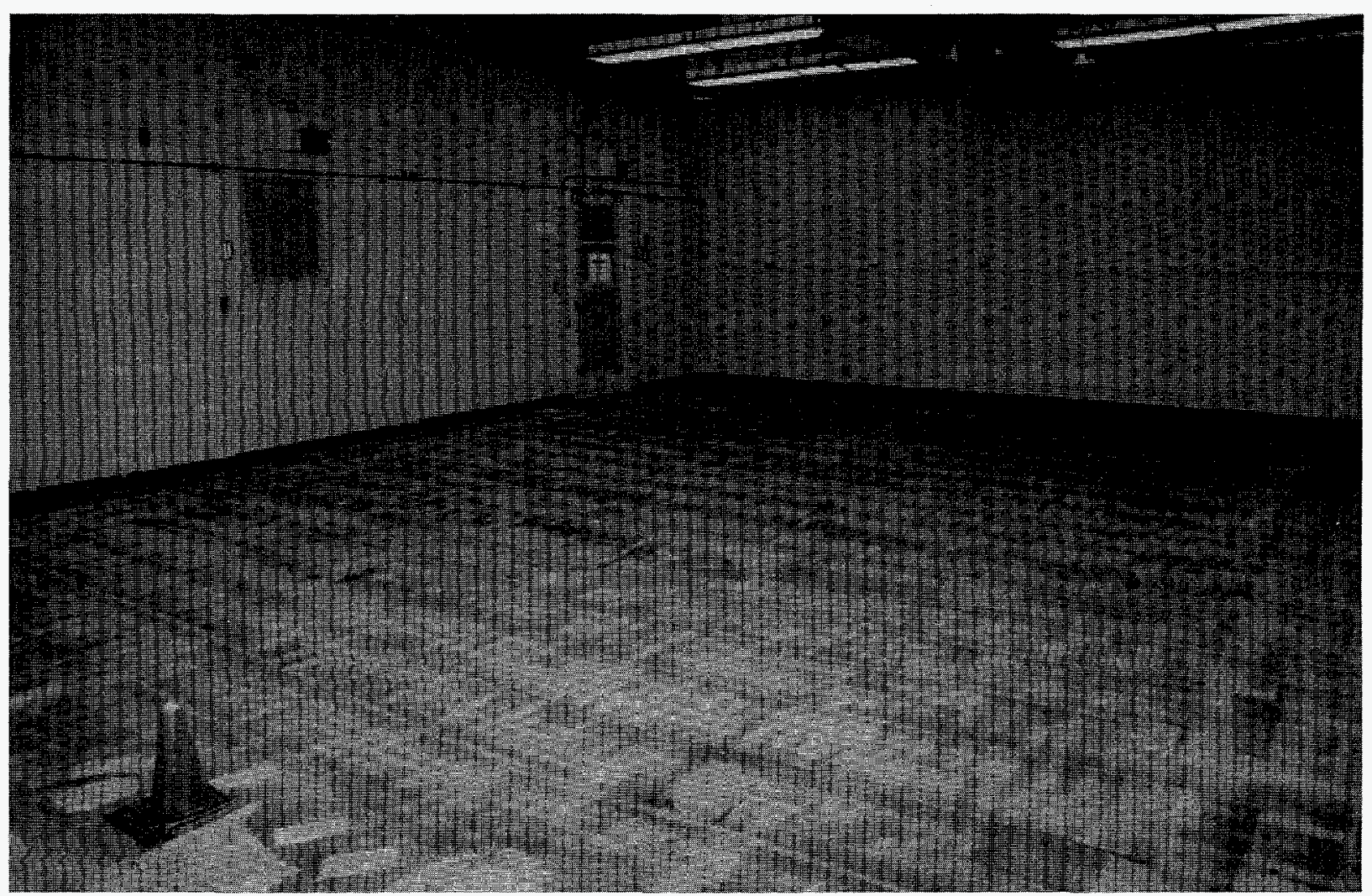

FIGURE 8.1 Final Status of Laboratory DL-216 (20930K \#17) 


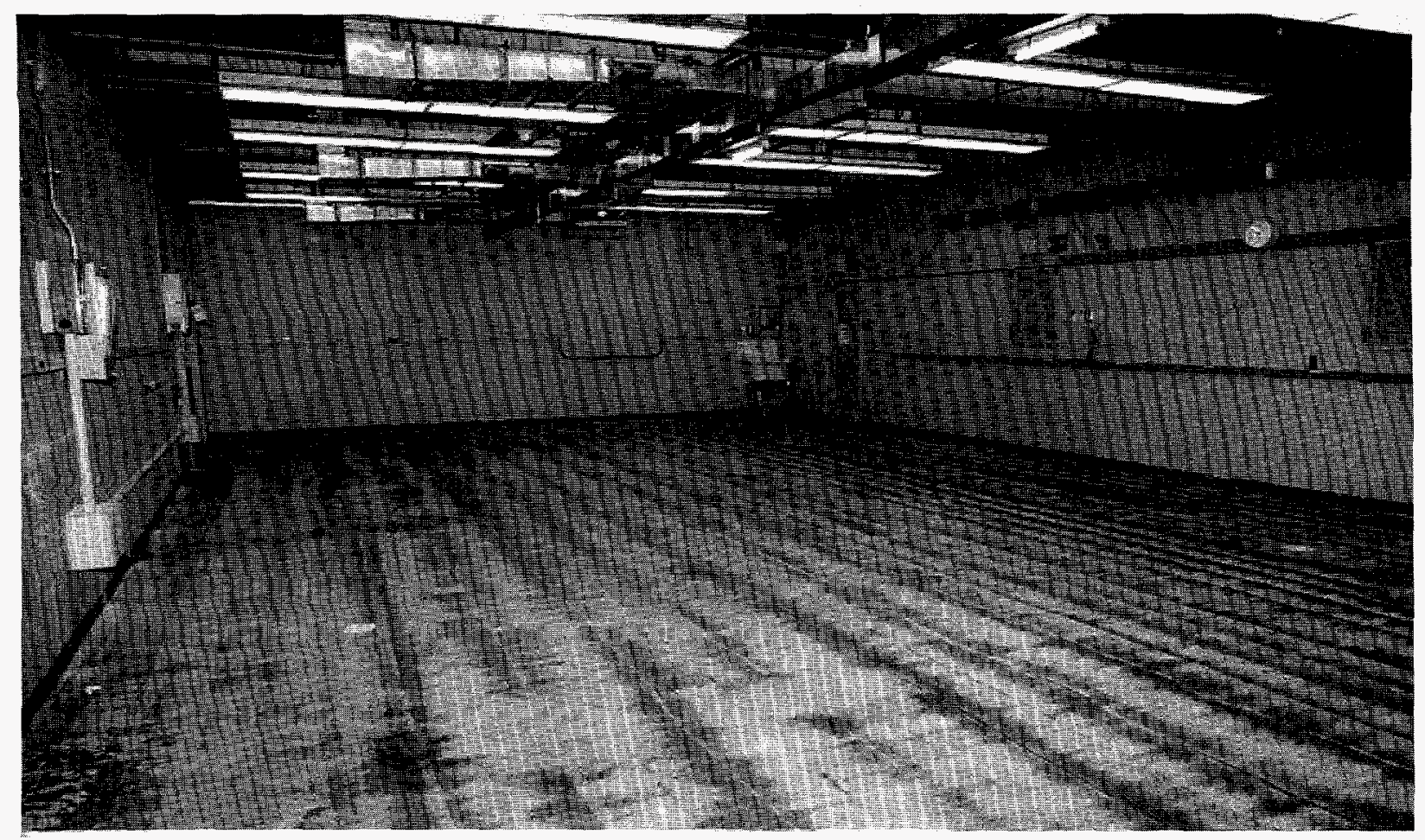

FIGURE 8.2 Final Status of Laboratory DL-222 (20830K \#19)

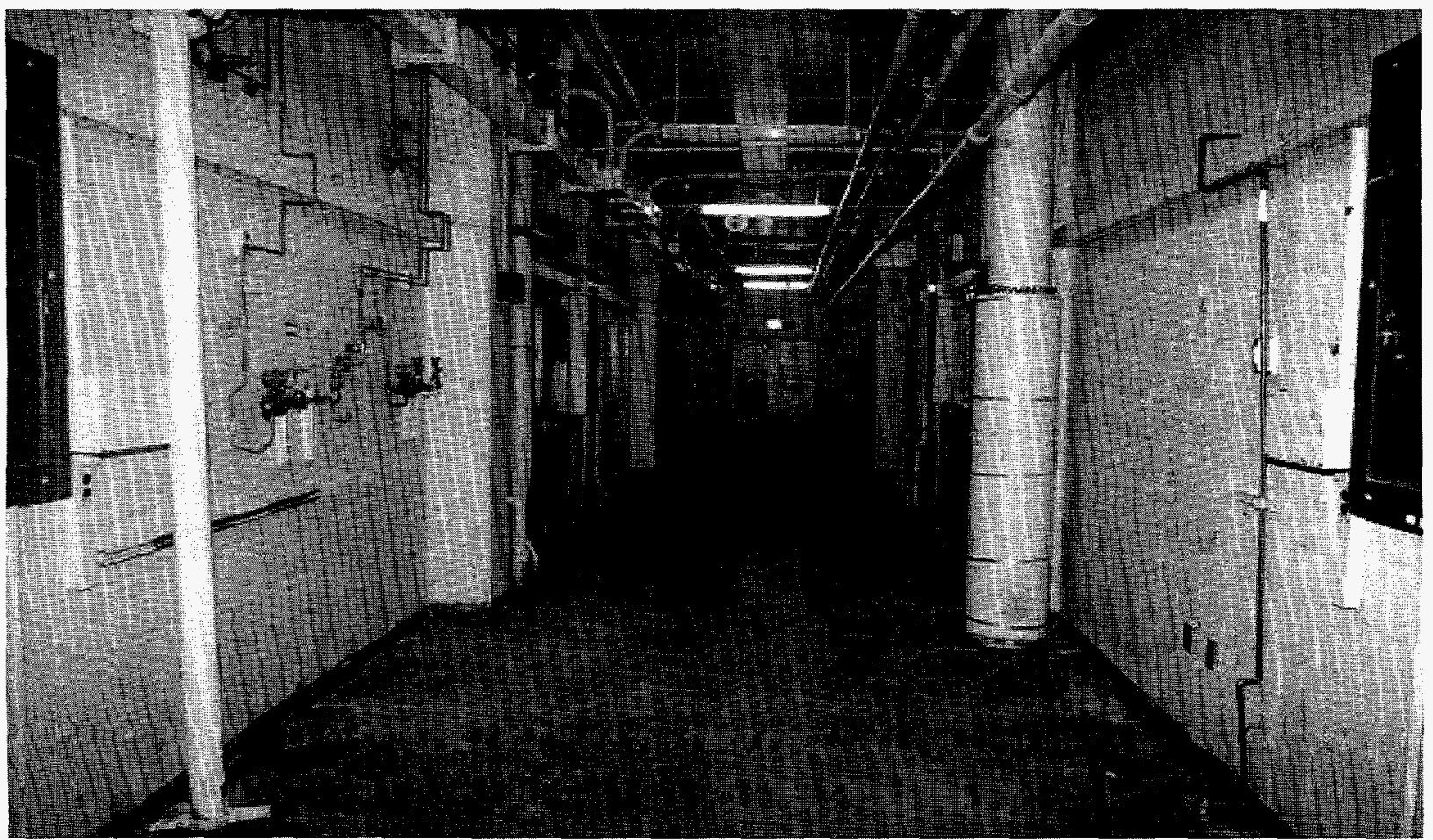

FIGURE 8.3 Final Status of Interior Corridor 26B (20830K \#23) 


\section{LESSONS LEARNED AND DOE REPORTABLE OCCURRENCES}

A number of lessons were learned during the D\&D work that resulted in safe and/or more effective work procedures. All DOE reportable off-normal occurrences for this project were detailed and each occurrence was reviewed for lessons learned and for indicated changes to avoid a recurrence.

\subsection{LESSONS LEARNED}

- Use of mockup training with plutonium glovebox size-reduction tools and control equipment was important for working safely and minimizing radiation exposures.

- Include work hold points in Radiation Work Permits to trigger review of conditions and controls needed for safe conduct of work. This led to timely improvements in procedures and controls. Typical hold points included designated air and surface contamination levels.

- Conduct work following requirements of Radiation Work Permits containing planned safety precautions. One of the occurrences in this decommissioning project was personal contamination resulting from workers handling a pouch containing bagged-out TRU materials in order to weigh it for packaging. The Radiation Work Permit for the glovebox bag-outs did not include this followon work so protective clothing and respiratory protection requirements were not defined. Task oriented Radiation Work Permits with worker input and/or review concurrence are important for minimizing risks.

- Remove all items from gloveboxes prior to final decontamination and painting to fix residual contamination. The highest airborne contamination inside the glovebox size-reduction enclosure resulted from the removal of a bolted-down unistrut during the glovebox size-reduction operations. This exposed a surface that did not have a fixative paint coating and led to the release of high-level airborne contamination in subsequent size-reduction work. The unistrut could have been unbolted and removed from the glovebox prior to the fixative painting step. 
- Aggressive techniques for removal of surface material are sometimes needed for effective decontamination. Use of an electrical orbital sander with coarse and/or medium/fine grit emery cloth was needed to remove radioactive contamination from some of the glovebox aluminum baseplates. The loosened radioactive contaminants were then removed with detergent wetted rags in order to reach non-TRU levels. This was especially important in gloveboxes where oil had been on the glovebox floor, such as in the lathe, milling machine, and Elox (electron beam cutting) gloveboxes.

- Both real time and retrospective air monitoring devices were useful for assessing air contamination. Personal lapel air filter samplers, fixed location air filter samplers, and a Continuous Air Monitor with an audible and a red light alarm were used to indicate air contamination conditions inside the glovebox size-reduction enclosure. The lapel air filter samplers and the fixed location air filter samplers were used for retrospective air contamination information and for exposure estimates pending analysis results of bioassay samples. The Continuous Air Monitor provided a signal to evacuate the glovebox size-reduction enclosure when air contamination levels exceeded 500 times the DAC guideline. This alarm point and evacuation action occurred only once during the glovebox size-reduction work.

- Local exhaust ventilation was effective for minimizing air contamination inside the glovebox size-reduction enclosure. Two movable flanged local exhaust hoods were used for contaminant capture during removal of glovebox windows and for power saw cutting of frames. A disposable cardboard box local exhaust enclosure was used for capture of radioactive dust generated during carbide tipped circular saw cutting of glovebox floor plates. All local exhaust ventilation was doubly HEPA filtered.

- Notches were cut into the end of the HEPA filtered vacuum cleaner pickup nozzle to reduce spread of contamination inside the glovebox size-reduction enclosure. The problem was that the nozzle would grip sheet plastic material which would be physically moved by efforts to move the nozzle and this produced air contamination.

- An intercom system was added to improve communications between personnel working inside and outside the plutonium gloveboxes size-reduction enclosure. This allowed personnel inside to easily request materials or communicate problems to those outside. It was also easy for those outside to direct the workers inside to change their actions when they observed that improvements could be made. 
- It was found that wrapping the glovebox frames in stretch-wrap plastic sheeting after removal of the glovebox windows was useful for confining contamination. This step was taken prior to saw cutting of the frames inside the glovebox size-reduction enclosure.

- Use of stretch-wrap plastic sheeting to cover the exterior of wooden bin liners before they were moved into the airlock area of the glovebox size-reduction enclosure helped to minimize the spread of radioactive contaminants. The stretch-wrap plastic sheeting was removed after a bin liner was loaded and the liner cover was nailed in place. The bin liner was removed from the airlock enclosure and surveyed for contamination immediately after removal of the stretch wrap plastic.

- Procedures were changed to require immediate removal of the O-ring window gasket following removal of a glovebox window. This was to avoid spread of contamination inside the glovebox size-reduction enclosure. Prior to this change, an O-ring gasket peeled out of its channel by gravity force and spread contamination.

- Procedures were changed to minimize radioactive dust generation during circular saw cutting of the glovebox base plates. The base plates were covered with a fiber paper pad, and sprayed with an aqueous clear paint coating. The power saw cut was then made through this covering and the base plate.

- Procedures were changed to provide for use of a clear plastic shield between the Sawz-All saw and the operator for cutting the glovebox frames. This was to minimize contamination of personal protective clothing.

- Procedures were changed to require HEPA vacuum cleaning of the circular saw after size-reduction of each glovebox. This minimized radioactive dust generation in subsequent use of the circular saw.

- It was found to be important, for safety and minimization of radiation exposures, to test the effectiveness of tools under mock up conditions. A Hurst-Jaws-of-Life cutting tool was tried for cutting mock-up glovebox aluminum frame pieces. The test cutting demonstrated that the tool did not have the capability of cutting through with a single cut and that on multiple cuts it did not save time as compared to the saw cutting. Also, on the final cut the cut piece was propelled up into the air. This was considered to be a safety risk. It was therefore decided to continue to use the circular saw cutting. 
- Personnel need to be thoroughly instructed and checked on the frisking technique for detection of alpha contamination. Good technique is required to avoid bringing contamination out of controlled areas. The frisker probe should be held about $0.63 \mathrm{~cm}(0.25 \mathrm{in}$.) away from the skin or clothing surface and moved at a rate of $2 \mathrm{~cm} / \mathrm{s}(0.8 \mathrm{in} . / \mathrm{s})$. Frisking in this manner takes about three minutes. The potential consequences of inadequate checking for alpha contamination need to be made clear to project personnel. When workers follow the recommended check-out procedure, the potential for contaminant transfer outside the controlled areas is minimized.

- Project team members need to check each other and remind all personnel to follow proper personal contamination check-out procedures in leaving the radioactive control area. Attention to detail is essential to prevent spread of radioactive contamination to uncontrolled areas.

\subsection{DOE REPORTABLE OCCURRENCES}

There were six DOE reportable off-normal occurrences for the plutonium glovebox D\&D project, as follows:

- CH-AA-ANLE-ANLEEWM-1993-0007 Final Report dated 12/06/1993. This off-normal occurrence was the discovery, by using a hand and shoe monitor, of $16.7 \mathrm{~Bq}(1,000 \mathrm{dpm}) \mathrm{alpha} / 100 \mathrm{~cm}^{2}$ on the shoe of a contractor employee as he checked out of laboratory DL-208 in Building 212. The occurrence was at 0900 central time zone, (CTZ) on 07/19/1993. The contamination was immediately removed with tape and a resurvey showed no contamination. Health Physics surveys of the laboratory and of adjacent areas did not detect contamination or the source of the shoe contamination. A complete survey of the floor in laboratory DL-208 and a review of contamination control procedures were carried out.

- CH-AA-ANLE-ANLEEWM-1993-0008 Final Report dated 12/06/1993. This off-normal occurrence was the contamination of the shoe soles of two ANL-E workers and of a section above the knee on the ANL-E work trousers of a third worker. The occurrence was at $1415 \mathrm{CTZ}$ on 07/24/1993. The workers were retaping a leaking vacuum pump line of a plutonium glovebox in laboratory DL-216, Building 212. Full facepiece respirators, magenta lab coats, and gloves were worn for this work. The highest contamination level was $26.7 \mathrm{~Bq}(1600 \mathrm{dpm})$ alpha/100 $\mathrm{cm}^{2}$ on the work trousers. The contamination was removed with tape to non-detectable levels. 
Corrective actions were:

- A survey of the work area was made, showing $16.7 \mathrm{~Bq}(1,000 \mathrm{dpm})$ / $100 \mathrm{~cm}^{2}$ on the floor near the vacuum pump and this was decontaminated to a non-detectable level.

- Work procedures were reviewed and revised to have hold points for evaluation and sign-off by Health Physics. A walk-through review of procedures was to be carried out prior to the start of work.

- Bioassay samples were analyzed and results were negative.

- CH-AA-ANLE-ANLEEWM-1993-0011 Final Report dated 04/06/1994. This off-normal occurrence was contamination of a worker's hand in laboratory DL-204, Building 212, during handling and weighting of a heat-sealed plastic bag of waste. The occurrence was at $1100 \mathrm{CTZ}$ on 09/22/1993. The heatsealed bag of TRU waste contained metal shelving that had been removed from a glovebox in laboratory DL-131, Building 212, the previous day. The hand contamination of $33.3 \mathrm{~Bq}(2,000 \mathrm{dpm})$ alpha/ $100 \mathrm{~cm}^{2}$ was discovered by a routine hand and shoe monitor check following the weighing of the bag. It was later observed that there was a $0.3 \mathrm{~cm}(0.125 \mathrm{in}$.) tear in the bottom of the bag that had not been noticed prior to weighing the bag. A magenta lab coat was worn by the worker but no respirator and no gloves were worn. The contamination was immediately washed off with soap and water to a none detectable condition. The tear in the waste bag was taped shut and no contamination was then found on the bag, on the weighing scale, or on the floor.

Corrective actions included:

- The procedure for taping sharp edges and bundling of materials in a glovebox prior to bag out was emphasized.

- A radiological survey was made of all work areas, and, where indicated, areas were decontaminated. Remaining fixed contamination areas were taped and posted.

- Radiological Work Permit procedures were emphasized as necessary for all radioactive work tasks. 
- Worker training was expanded to include a walk-through preview and signoff of all step-by-step procedures.

- The radiation control monitoring stations were enlarged and improved.

- CH-AA-ANLE-ANLEER-1994-0001 Final Report dated 07/20/1994. This off-normal occurrence was contamination of the protective clothing and skin of a contractor technician who was working through glovebox gloves to disassemble glovebox equipment. The occurrence was at $1400 \mathrm{CTZ}$ on 03/30/1994. The technician was wearing toe rubbers, a magenta labcoat, and two pair of latex rubber gloves with scrub greens under the lab coat. He was working at a glovebox in laboratory DL-216, Building 212, and on surveying his gloves with the laboratory survey instrument he found the left glove was contaminated. He removed his gloves and placed them in a radioactive waste container. He exited the lab and, after removal of his magenta lab coat, the corridor hand and shoe monitoring showed that his left hand was contaminated. The technician asked for assistance and the Health Physics technician who assisted found $46.7 \mathrm{~Bq}(2,800 \mathrm{dpm})$ alpha contamination of the little finger of the right hand and of the left wrist. The contamination was readily washed off at a decontamination sink and the protective clothing was placed in a radioactive waste container. The magenta labcoat, which had been removed, had $83.3 \mathrm{~Bq}(5,000 \mathrm{dpm})$ alpha contamination on each lower sleeve.

Investigation determined the source of the contamination was two tears, $7.6 \mathrm{~cm}$ ( 3 in.) and $2.5 \mathrm{~cm}$ ( 1 in.) long, in a glovebox glove that the technician had used. The glove had been stretched in reaching across the box while using pliers and this was thought to be the cause of the tears. Follow-up bioassay results indicated that the 50 year committed dose to the technician from this occurrence would be less than $0.5 \mathrm{mSv}$ ( $50 \mathrm{mrem}$ ).

Corrective actions were:

- The glovebox gloves were changed prior to further work in the glovebox. Procedures were revised to stress careful inspection of glovebox gloves and replacement as needed prior to usage. A revised procedure warned not to stretch glovebox gloves and to obtain immediate assistance to confine contamination when it was detected. 
- CH-AA-ANLE-ANLEER-1994-0010 Final Report dated 02/01/1995. This off-normal occurrence report was for intake of radioactivity detected in bioassay program fecal samples for the Building 212 plutonium gloveboxes decommissioning project. The occurrence was over a period of several months and was dated 09/19/1994 when analyses were completed of fecal samples from seven contractor personnel whom had completed their work and demobilized. The fecal samples indicated $\mathrm{Pu}-239, \mathrm{Pu}-240$, and Am-241 radioisotopes were present at low but detectable levels. Analyses of urine samples produced negative results. It is believed the internal exposures of less than $1 \mathrm{mSv}$ (100 mrem) 50 year committed dose were due to low-level intermittent ingestion and/or inhalation of radioactive materials.

Corrective actions included:

- Place greater emphasis on work place "good house keeping" including frequent wipe downs and mopping of work and boundary areas.

- Place increased emphasis on evaluating workplace contamination surveys and workplace air samples to identify trends. 


\section{CONCLUSIONS AND RECOMMENDATIONS}

\subsection{CONCLUSIONS}

Nine plutonium glove-box laboratories containing 61 glove-boxes were successfully decommissioned and released for unrestricted use. The coordinated use of ANL-E and contractor personnel was effective in accomplishing the objectives. The use of active-passive neutron assay instrumentation large enough to accommodate the plutonium gloveboxes was a noteworthy tool for completing the task. The attention to ALARA principles allowed completion of the project with a collective effective dose equivalent (CEDE) of $14.6 \mathrm{mSv}$ (1.46 rem), which was $34 \%$ of the forecasted CEDE.

\subsection{RECOMMENDATIONS}

It is recommended that active-passive neutron assay systems be used for assaying plutonium gloveboxes in decommissioning tasks such as this one. 


\section{REFERENCES}

01. Conceptual Design Report (CDR), "Decontamination and Decommissioning of Hot Cells and Other Facilities" (200, 212, 203, 301), Document No. J9001-3600-SA-01, Argonne National Lab, January 1990.

02. "Safety Analysis Report for the Decontamination and Decommissioning of Plutonium Glove Boxes and Certification of Laboratories in Building 212, D Wing, at Argonne National Laboratory - East", July 1992.

03. "Action Description Memorandum for Decommissioning of Plutonium Glove Boxes and Certification of Laboratories in Building 212, D Wing, at Argonne National Laboratory East", July 1992.

04. "ANL-E Environment, Safety and Health Manual", Volumes 1 and 2, April 1991, (continually updated), Includes ANL-E Radiological Control Manual.

05. “ANL-IL Waste Handling Procedures Manual”, February 1991, (continually updated).

06. “ANL Quality Assurance Program Plan”, February 1993.

07. “ANL Quality Assurance Planning Guide”, November 1993.

08. "Assessment of Options for the D\&D of Plutonium Gloveboxes - Building 212", Document No. RT/DN/3095/001, June 28, 1993.

09. "Waste Acceptance Criteria for the Waste Isolation Pilot Plant", WIPP-DOE-069 Revision 4.0, December 1991.

10. "Personnel Selection, Qualification, Training, and Staffing Requirements at DOE Reactor and Non Reactor Nuclear Facilities", DOE Order 5480.20, February 20, 1991.

11. "Radiation Protection for Occupational Workers", DOE Order 5480.20, July 20, 1989.

12. "Radiation Protection of the Public and Environment", DOE Order 5400.5, June 5, 1990.

13. “Radioactive Waste Management”, DOE Order 5820.2A, September 26, 1988.

14. "Implementation of the National Environmental Policy Act", DOE Order 5440.1C, April 9, 1985.

15. "Unusual Occurrence Reporting System", DOE Order 5000.3, November 7, 1984. 
16. "A Guide to Maintaining Exposures ALARA", PNL-6577.

17. "Verification Survey of the Building 212 D-Wing Glove Box Area Decontamination and Decommissioning Project Argonne National Laboratory-East Argonne, Illinois", by T.J. Vitkus and T.D. Herrera, ORISE, June 1996. 